\title{
Aspectos comportamentais de Perdiz (Rhynchotus rufescens) em cativeiro durante a fase reprodutiva. Um estudo de caso.
}

\section{José Eduardo Peixoto}

Dissertação de Mestrado depositada na Seção de Pós-Graduação da Faculdade de Zootecnia e Engenharia de Alimentos da USP , como parte dos requisitos para a obtenção do Título de Mestre em Zootecnia, na área de Concentração: Qualidade e Produtividade Animal.

Orientador: Profa. Dra. Maria Estela Gaglianone Moro 
FACULDADE DE ZOOTECNIA E ENGENHARIA DE ALIMENTOS

\title{
Aspectos comportamentais de Perdiz (Rhynchotus rufescens) em cativeiro durante a fase reprodutiva. Um estudo de caso.
}

\section{José Eduardo Peixoto}

Profa. Dra. Maria Estela Gaglianone Moro orientador

\begin{abstract}
Dissertação de Mestrado apresentada à Faculdade de Zootecnia e Engenharia de Alimentos da USP, como parte dos requisitos para a obtenção do Título de Mestre em Zootecnia, na área de Concentração: Qualidade e Produtividade Animal.
\end{abstract}


Peixoto, José Eduardo.

P377a Aspectos comportamentais de Perdiz (Rhynchotus rufescens) em cativeiro durante a fase reprodutiva: um estudo de caso / José Eduardo Peixoto. --Pirassununga, 2002.

Dissertação (Mestrado) -- Faculdade de Zootecnia e Engenharia de Alimentos, Universidade de São Paulo. Departamento de Zootecnia.

Área de concentração: Qualidade e Produtividade Animal. Orientador: Prof ${ }^{\mathrm{a}}$. Dra ${ }^{\mathrm{a}}$ Maria Estela Gaglianone Moro.

Unitermos: 1. Rhynchotus, cativeiro 2. Rhynchotus, criação

3. Rhynchotus, comportamento 4. Rhynchotus, reprodução

I. Título. 


\section{Dedico,}

com todo amor e carinho a minha esposa Jessica e a meu filho Victor, que sempre me apoiaram nas horas difíceis e me compreenderam nas minhas faltas. 
Ofereço,

Aos meus pais, Albino e Dalva, pelo exemplo, incentivo, apoio, carinho e amor em todos os momentos. 


\section{Agradecimento Especial}

À Profa. Dra. Maria Estela Gaglianone Moro, pela orientação, amizade, confiança e incentivo, contribuindo de maneira fundamental para minha formação profissional.

Ao Dr. Valter $\boldsymbol{U}$. Cromberg, pela contribuição fundamental à este trabalho e pelo exemplo de honestidade, dedicação, perseverança e principalmente, pela tenacidade na defesa de seus ideais.

\section{Muito Obrigado}




\section{AGRADECIMENTOS}

Aos Profs. que participaram desta jornada, pelos ensinamentos e crescimento profissional proporcionados.

Aos funcionários da FZEA que com muito carinho desempenharam suas funções, possibilitando a realização deste trabalho.

À esta Instituição pela oportunidade proporcionada.

Aos amigos Zé Luís, Ricardo, Isac, Juliano e Alex, pela amizade e companheirismo.

À Érica (ZAZ) pela presteza e gentileza durante o curso.

À Cláudia pela "força" na revisão.

$\mathrm{E}$ a todos que de alguma forma colaboraram e porventura esqueci de citar,

\section{Muito obrigado}




\section{ÍNDICE}

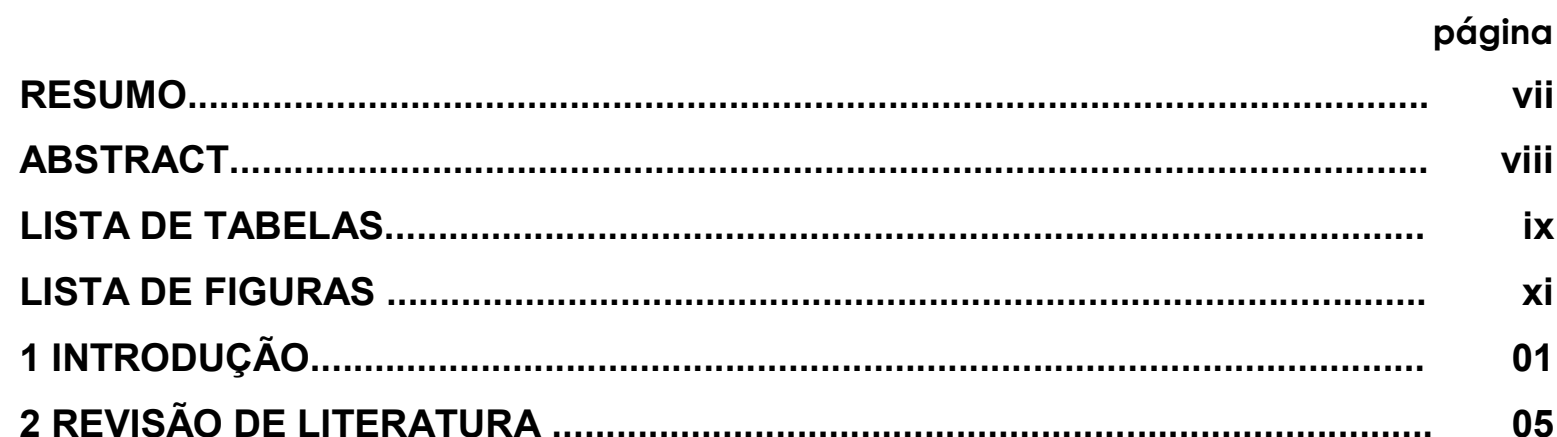

2.1 Rhynchotus rufescens .................................................................... 05

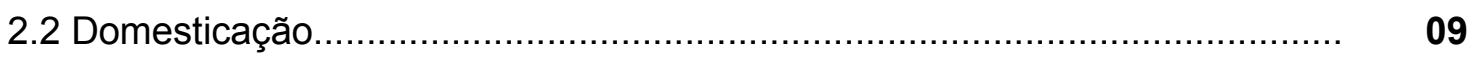

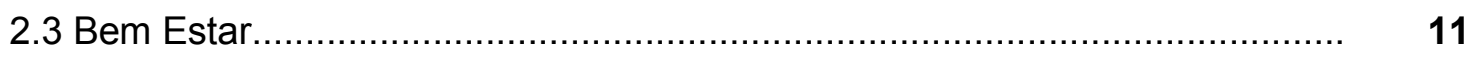

2.4 Sistemas de Acasalamento............................................................... 11

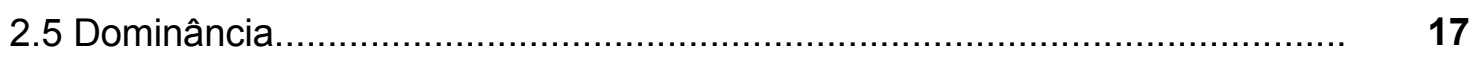

3 MATERIAL E MÉTODOS ….......................................................................... 18

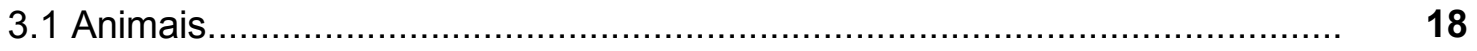

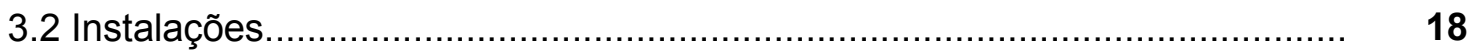

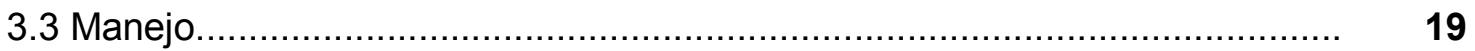

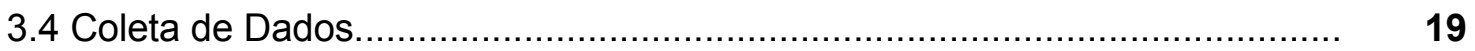

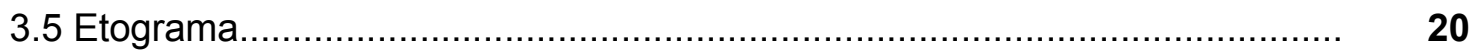

3.6 Análises Estatísticas..................................................................... 21

4 RESULTADOS

4.1 Distribuição Freqüêncial do Repertório Comportamental.............................. 23

4.2 Freqüência Horária das Principais Categorias Comportamentais.................. $\quad 35$

4.3. Freqüências de Surtos Absolutos de Comportamento................................ 43

4.4 Análise dos ritmos diários de atividade de alguns comportamentos............. $\quad 46$

4.5 Organização do Comportamento da Perdiz no Cativeiro............................... 48

4.5.1 Interpretação dos Diagramas em Forma de Árvores.............................. $\quad 48$

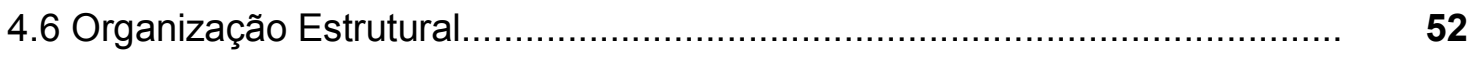

4.7 Dominância e Distribuição Espacial......................................................... 57

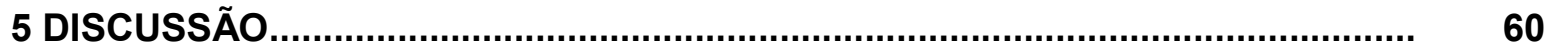

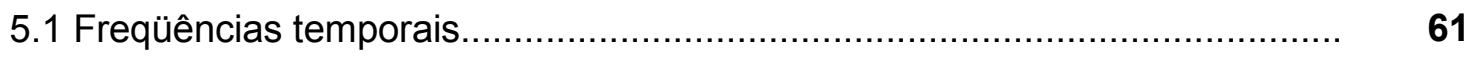

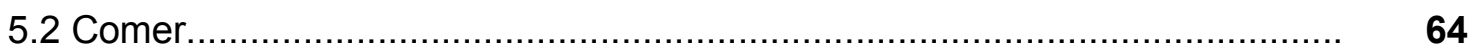

5.3 Dominância e o uso do espaço.................................................................... 70 


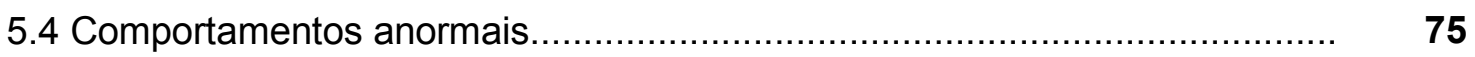

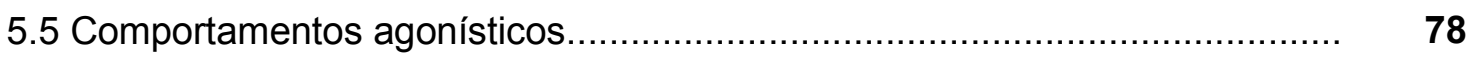

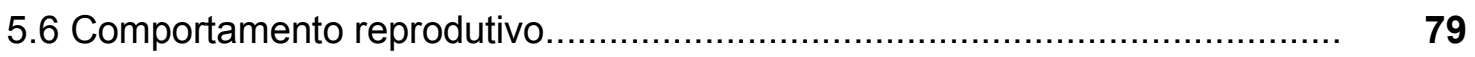

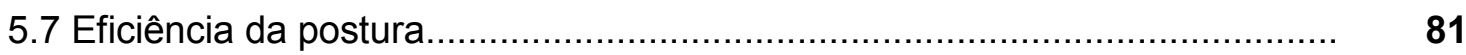

5.8 Organização seqüencial dos comportamentos de perdizes........................ 82

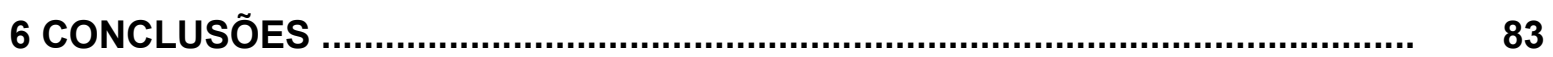

7 REFERÊNCIAS BIBLIOGRÁFICAS......................................................... 84

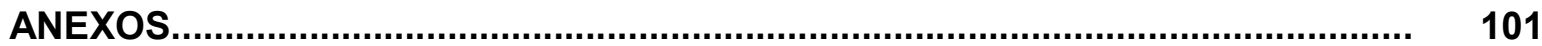


PEIXOTO, J. E. Aspectos comportamentais de Perdiz (Rhynchotus rufescens) em cativeiro durante a fase reprodutiva. Um estudo de caso. 2002, 104 p. Dissertação de Mestrado - Faculdade de Zootecnia e Engenharia de Alimentos, Universidade de São Paulo, São Paulo.

A espécie Rhynchotus rufescens, ave nativa do Brasil, denominada popularmente perdiz ou perdigão tem mostrado facilidade de adaptação ao cativeiro, e um ótimo potencial para ser explorada zootecnicamente, com a possibilidade da utilização de sua carne como fonte alternativa de proteínas, já que a carne de animais silvestres é uma alternativa alimentar em muitos países, inclusive nos desenvolvidos. A criação de perdizes de maneira racional poderia aumentar as opções da avicultura brasileira e a produção alternativa de proteína animal. O presente trabalho, identificou ritmos diários de atividades da perdiz e seu esquema de alocação temporal em uma situação de cativeiro. 0 conhecimento destes dados é de fundamental importância para o manejo alimentar e reprodutivo destes animais. Os dados coletados de cada lote foram feitos através de filmagem durante 12 horas ininterruptas, do amanhecer ao entardecer, por três dias consecutivos, totalizando 36 horas de filmagens. $O$ material resultante das filmagens foi observado para obtenção da série de dados utilizados para as análises temporais, utilizando-se o sistema de amostragem temporal (time sampling) para a observação dos comportamentos das aves. Neste trabalho, determinou-se alguns padrões comportamentais de perdizes (Rhynchotus rufescens), nas condições propostas. Os ritmos associados às atividades e sua distribuição temporal foram quantificados e avaliados. Mostrouse como a organização estrutural dos comportamentos ocorrem. Questões mais complexas como a distribuição espacial, o uso do espaço físico e social, com suas interações agonísticas e de dominância foram abordadas, e indicaram problemas de bem estar, provavelmente comprometendo a eficiência reprodutiva destes animais no cativeiro. Trabalhos futuros deverão estar atentos a estas questões. A investigação de um sistema de acasalamento eficaz é considerado fundamental para obter-se sucesso na criação desta espécie, e então partirmos para sua seleção, lembrando contudo, de estabelecer limites para esta, baseados em índices comportamentais da espécie, a fim de não incorrer-se nos erros que agora são nítidos com relação às aves especializadas para corte e postura.

Palavras chave: Rhynchotus, comportamento, cativeiro, criação, reprodução. 
PEIXOTO, J. E. Behavioural aspects of the Partridge (Rhynchotus rufescens) in captivity during the reproductive phase. A case study. 2002, 104 p. Dissertation of Master Degree - Faculty of Zootechny and Food Engineering, University of São Paulo, São Paulo.

The species Rhynchotus rufescens, a native bird of Brazil, popularly denominated partridge or pellet, has been showing easy adaptation to captivity and a great potential to be explored zootechnically, with the possibility of the use of its meat as an alternative source of proteins, since the meat of wild animals is a nourishment alternative in many countries, including developed ones. The breeding of partridges in a rational way could increase the options of Brazilian avilculture and the alternative production of animal protein. The present work identified the daily rhythms of activities of the partridge and its scheme of temporary allocation in a situation of captivity. The knowledge of these data is of fundamental importance for the alimentary and reproductive handling of these animals. Data related to each lot were collected through twelve uninterrupted hours of filming, from dawn to dusk, for three consecutive days, totalizing thirtysix hours of work. The material resultant from the filmings was observed in order to obtain the series of data used for the temporary analyses, having the system of temporary sampling (time sampling) been used for the observation of the behaviour of the birds. In this work, it was determined some standard behaviour of partridges (Rhynchotus rufescens), under the proposed conditions. The rhythms associated with the activities and their temporary distribution were quantified and appraised. It was shown how the structural organization of their behaviour take place. More complex subjects as space distribution, the use of physical and social space, with its agonistic and dominance interactions were approached, and they indicated problems of well being which probably interfered in the reproductive efficiency of these animals in captivity. Future works should be aware of and pay attention to these subjects. The investigation of a system of effective copulation is considered fundamental to obtain success in the breeding of this species, leading, then, to its consequent selection. Nevertheless, it is essential that limits based on behavioural indexes of the species be established, which will avoid incurring in the mistakes that are now clear in relation to specialized birds for slaughter and posture.

Words key: Rhynchotus, behaviour, captivity, breeding, reproduction. 


\section{LISTA DE FIGURAS}

FIGURA

página

1. Exemplar da espécie Rhynchotus rufescens............................................. 06

2. Distribuição geográfica da Rhynchotus rufescens................................... 07

3. Esquema ilustrativo do espaço individual e a distância de fuga nos animais.

4. Distribuição da porcentagem de freqüência ajustada da categoria deslocamento (DE) para os animais estudados.

5. Distribuição da porcentagem de freqüência ajustada da categoria ciscar (CS), para os animais estudados

6. Distribuição da porcentagem de freqüência ajustada da categoria comer (CO), para os animais estudados.

7. Distribuição da porcentagem de freqüência ajustada da categoria imobilidade (IM), somatória de parado (PA) e sentado imóvel (SP), para os animais estudados.

8. Porcentagem da freqüência da categoria arrumação (AR) dos animais do box A..

9. Porcentagem da freqüência da categoria arrumação (AR) dos animais do box B..

10. Porcentagem da freqüência da categoria comer $(\mathrm{CO})$ dos animais do box A.

11. Porcentagem da freqüência da categoria comer $(\mathrm{CO})$ dos animais do box B.

12. Porcentagem da freqüência da categoria imobilidade (IM) dos animais do box A.

13 Porcentagem da freqüência da categoria imobilidade (IM) dos animais do box B.

14 Freqüência média para a categoria deslocamento (DE) no terceiro dia de observações.

15 Freqüência média para a categoria parado (PA) no terceiro dia de observações.

16 Porcentagem de freqüência média para a categoria ciscar (CS) no terceiro dia de observações. 
17 Porcentagem de freqüência média para a categoria arrumação (AR) no terceiro dia de observações.....................................................................

18 Porcentagem de freqüência média para a categoria sentado inativo (SP) no terceiro dia de observações...

19 Porcentagem de freqüência média para a categoria comer (CO) no terceiro dia de observações........................................................................ 41

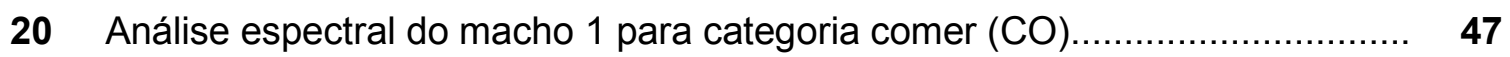

21 Árvore orientada mais provável do ato parado (PA) como raiz, solução fonte, obtida a partir da matriz de transição das fêmeas.................................... 49

22 Árvore orientada mais provável das fêmeas, raiz PA é sumidouro................... 51

23 Árvore tendo o deslocamento (DE) como raiz fonte para fêmeas................... 53

24 Árvore tendo o deslocamento (DE) como raiz fonte para machos................... 53

25 Árvore tendo o deslocamento (DE) como sumidouro para fêmeas.................. 54

26 Árvore tendo o deslocamento (DE) como sumidouro para machos................. 54

27 Em (A) a raiz SP é fonte, em (B) é sumidouro para machos e 55 fêmeas

28 Associações seqüenciais observadas. Em (A) DE é raiz, (B) AR é raiz e em

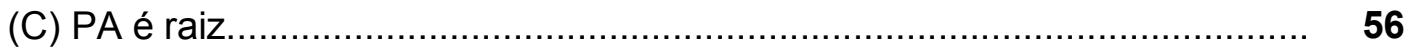




\section{LISTA DE TABELAS}

Tabela

página

1. Porcentagem de freqüência média de ocorrência dos comportamentos observados das 6:55 h. às 19:50 h.

2. Correlação de Pearson para os comportamentos que mostraram valores significativos $\mathrm{p}<0,05$.

3. Porcentagem de freqüências médias de ocorrência dos comportamentos mais significativos, observados das 6:55 h. às 19:50 h. para os animais agrupados por box.

4. Freqüência dos atos comportamentais para os animais observados; agrupados em média entre fêmeas e entre machos...

5. Freqüência dos atos comportamentais para os animais observados; agrupados em média de fêmeas e machos e como média para cada um dos boxes.

6. Matriz de comportamentos agonísticos entre os animais do box A. 58

7. Matriz de comportamentos agonísticos entre os animais do box $B$ 
O que eu vejo na natureza é uma magnífica estrutura, que só conseguimos compreender com muita imperfeição, mas que pode satisfazer a uma pessoa com sentimento de humildade. 


\section{INTRODUÇÃO}

A espécie Rhynchotus rufescens, ave nativa do Brasil, denominada popularmente perdiz ou perdigão tem mostrado propensão a adaptação ao cativeiro, e um ótimo potencial para ser explorada zootecnicamente, com a possibilidade da utilização de sua carne como fonte alternativa de proteínas, já que a carne de animais silvestres é uma alternativa alimentar em muitos países, inclusive nos desenvolvidos. Sabe-se que em algumas regiões do mundo, a carne de caça constitui-se em importante fonte de proteína animal para o consumo humano (MORO, 1996).

Além da necessidade de novas fontes de proteína animal, seria benéfico aumentar a diversidade de animais domésticos para fins científicos, uma vez que cada espécie poderia ser mais eficiente a determinados tipos de experimentação (HUCK \& PRICE, 1975). Um outro aspecto a salientar, inclusive no caso da perdiz, objeto de caça predatória e extrativismo, seria a preocupação com políticas para o manejo da espécie, visando sua preservação, uma vez que a espécie se encontra em situação crítica na natureza (SMA, 1998). No Brasil, a quase totalidade de carne de caça comercializada nos centros urbanos é proveniente de espécies exóticas; até tempos recentes a população rural era pródiga no consumo de carnes oriundas da caça de espécies nativas. 
A criação de perdizes de maneira racional poderia aumentar as opções na avicultura brasileira e a produção alternativa de proteína animal. A evolução no desempenho zootécnico verificado em aves totalmente domesticadas, como a galinha, indica que se partiu de índices produtivos semelhantes aos observados ainda na condição selvagem da ave e, por meio da atuação multidisciplinar das diferentes áreas da zootecnia e veterinária envidou-se esforços numa única direção, tornando a atividade economicamente viável.

Desta forma, o desenvolvimento de vários estudos para sua criação em cativeiro possibilitaria um maior conhecimento da espécie, essencial para a criação destas aves em cativeiro, pois diversos autores, como a semelhança de THOLON (2002), afirmam pouco se saber do comportamento sexual dos animais, e de como seu desempenho reprodutivo em cativeiro é afetado pelas condições do estresse a que as aves são submetidas, ou de CARNIO et al. (1999) que cita a necessidade de mais estudos para esclarecer a diversidade de resultados da reprodução de perdizes em cativeiro, com ênfase nos aspectos nutricionais, etológicos e de manejo. Os conhecimentos gerados por investigações dos comportamentos dos animais têm sido utilizados cada vez com maior freqüência para melhorar as estratégias de manejo dos animais e o desenvolvimento de novas técnicas de produção. Por sua vez, a obtenção de dados coletados na natureza devem ser vistos com cuidado, pois poderiam ser erroneamente interpretados na situação de cativeiro, uma vez que condições ambientais encontradas na natureza e no cativeiro influem diferentemente no comportamento e bem-estar destes animais (FRANÇOIS et al.,1998).

O caminho para que o potencial zootécnico desta espécie seja otimizado, pensando na sua exploração comercial, passa assim necessariamente pelo conhecimento mais amplo de sua biologia, inclusive dos detalhes de seu comportamento. MAULDIN (1991) mostrou que os comportamentos sociais, agonísticos e reprodutivos são os fatores 
preponderantes para otimizar a administração de granjas de aves em escala comercial, viabilizando a criação e utilizando-a inclusive como estratégia de preservação, pois uma das estratégias para proteger espécies ameaçadas de extinção tem sido o estabelecimento de colônias criadas artificialmente em cativeiro, com a finalidade de restabelecer populações ferais em seu ambiente natural.

Dentro de um processo de domesticação, muitas vezes é necessário se decidir entre o investimento nos comportamentos típicos da espécie observada em ambiente natural e adaptá-los ao cativeiro ou se seria mais vantajoso investirmos na seleção de novas respostas comportamentais impostas pelas condições de cativeiro, pois indubitavelmente, o manejo dos animais de produção altera significativamente seu ambiente social (DAWKINS, 1980). Por exemplo, o incremento da densidade populacional em relação à vida em liberdade, causa um aumento na competição intraespecífica principalmente em relação à alimentação e ao acasalamento. Quanto a este ultimo, poderíamos dizer que na natureza o sistema de acasalamento nada mais é do que um conjunto de estratégias onde cada indivíduo da população poderia adotar uma estratégia diferente, elegendo aquela que for mais vantajosa para suas condições particulares (CARRANZA, 1994). A domesticação correlaciona-se à adaptação ao cativeiro através de combinações de mudanças genéticas ocorrendo sobre sucessivas gerações, incluindo as alterações induzidas pelo ambiente no desenvolvimento de cada geração. Práticas de manejo, ou eventos ambientais, influenciam o desenvolvimento de tratos biológicos específicos, podendo facilitar a adaptação (PRICE, 1984).

Em ambiente natural, a característica temporal dos padrões de atividades dos animais, reflete muitas vezes os próprios ciclos naturais (como a duração do dia e das estações, por exemplo), refletindo todo o processo de evolução. Estes padrões de atividades podem ser identificados em diversas funções, entre elas o ciclo de sono, atividade e alimentação. A 
análise matemática e estatística dos padrões temporais de ciclos de atividades, tem se baseado essencialmente em técnicas de análise espectral através da transformada de Fourrier. Uma análise das características temporais destas funções tem como objetivo descrever seus componentes rítmicos e investigar os mecanismos que regulam sua expressão.

As informações sobre perdizes, notadamente as comportamentais e sociais, são escassas e pouco confiáveis, por serem em grande parte anedóticas, provenientes de caçadores e mateiros. No cativeiro, apesar da manifestação dos ritmos naturais, sabe-se que estes tendem a ser influenciados por fatores ambientais - "zeitgeber" - (iluminação artificial, fornecimento de alimentos, rotinas de manejo, etc.) capazes de modificar os ritmos endógenos, impondo a eles o seu período.

Pretende-se no presente trabalho, identificar ritmos diários de atividade e seu esquema de alocação temporal em uma situação padrão de cativeiro; para futuras comparações com dados obtidos em ambiente natural e em situações experimentais. Os conhecimentos destes dados podem ser fundamentais quando se pensa em acertar o manejo alimentar e reprodutivo destes animais.

Torna-se importante, portanto, estudar o comportamento de Tinamídeos, frente aos diversos fatores que os pressionam, tendo em vista seu potencial econômico (PACHECO et al., 1994).

A pretensão deste trabalho foi identificar ritmos diários de atividade e seu esquema de alocação temporal em uma situação de cativeiro através da:

1. Determinação de alguns padrões do comportamento de perdizes durante a época reprodutiva da espécie;

2. Identificação de ritmos diários de atividade e seu esquema de alocação temporal em uma situação específica de cativeiro; 
3. Investigar padrões comportamentais como indícios de adaptação e bem-estar destas aves em cativeiro.

Os conhecimentos destes dados ;poderão ser fundamentais para melhorar o manejo alimentar e reprodutivo destes animais.

\section{REVISÃO DA LITERATURA}

\subsection{Rhynchotus rufescens}

A Rhynchotus rufescens (Figura 1) pertence à ordem Tinamiformes, a qual compreende um grupo de aves terrícolas de aparência galinácea, semelhante às perdizes do velho mundo (Alectoris e Perdix) apesar destas pertencerem à outra ordem de aves (CRAVINO, s.d.). As perdizes são muito citadas devido ao seu valor cinegético, pertencem a avifauna mais antiga deste continente, com distribuição restrita ao continente sul americano (SICK, 1997), com semelhanças morfológicas e bionômicas com os ratitas (MCDOWELL, 1948; PARKERS \& CLARK, 1966; GYSELS, 1970). 


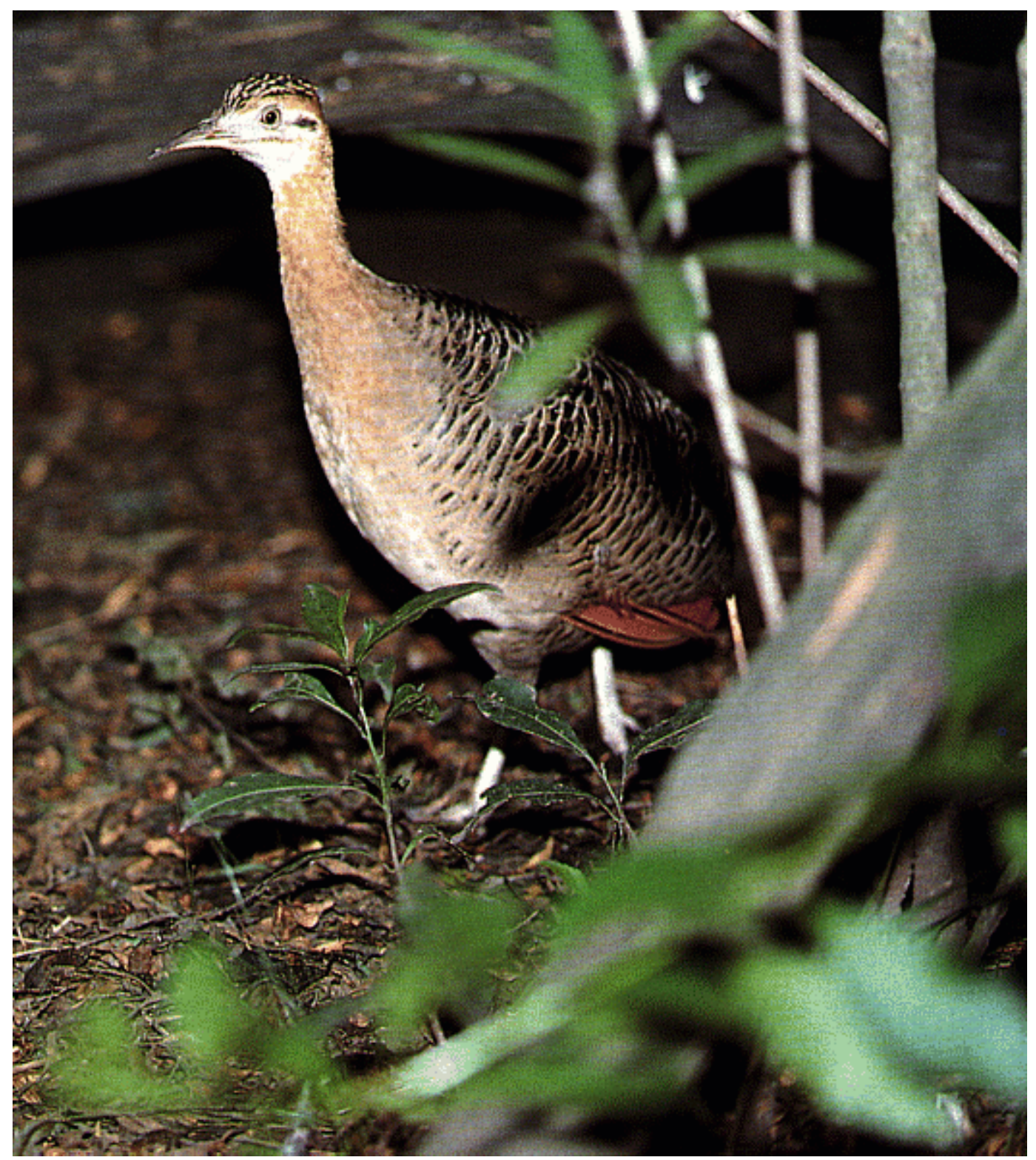

FIGURA 1 - Exemplar da espécie Rhynchotus rufescens. (DEL HOYO, 1992).

A perdiz é encontrada em regiões campestres, cerrados, buritizais e planaltos descampados (SICK, 1997), do norte da Bolívia ao leste do Brasil, de sul a leste do Paraguai e no nordeste da Argentina e Uruguai (DEL HOYO, 1992) (Figura 2). 


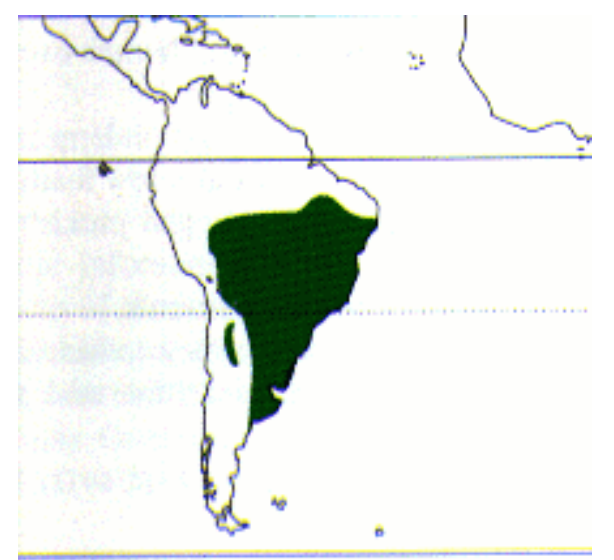

FIGURA 2 - Distribuição geográfica da Rhynchotus rufescens.(DEL HOYO, 1992).

Esta ave pertence à família Tinamidae, que possui vinte e duas espécies divididas em duas subfamílias: Tinaminae, com 2 gêneros e 17 espécies de macucos, jaós e inhambus, e Nothurinae, que inclui 3 gêneros com 5 espécies de codornas e perdizes (WALLACE \& MAHAN, 1975; SANTOS,1979; SICK, 1997).

Rhynchotus rufescens tem pernas fortes e pés pequenos, em comparação com outros pássaros terrestres de tamanho semelhante. Seus pés provavelmente se tornaram reduzidos como uma adaptação para locomoção através de vegetação densa (WEEKS, 1973), possuem asas bem definidas e arredondadas, e em vida livre usa seu bico forte, longo e curvo para cavar a terra à procura de raízes e tubérculos além de se alimentar de insetos (SICK, 1997).

Seu período reprodutivo ocorre de agosto a março, e tem como característica a vocalização dos machos, um piado peculiar bastante conhecido, o qual antecede o período fértil em um ou dois meses. O sistema de acasalamento é classificado por alguns autores como poliândrico (CRAVINO, s.d.; MENEGHETI, 1981; FOWLER, 1986). Os ovos são de cor vinácea ou chocolate violáceo, tido como os mais belos que se conhecem, sendo brilhantes e parecidos com porcelana. Tal coloração é desbotada em 
poucos dias, motivo pelo qual há tanta divergência na descrição da cor de seus ovos (SICK, 1997).

As perdizes têm hábitos sedentários (MENEGHETI \& MARQUES, 1981), aninhando-se comumente nos lugares onde vivem (MONTES, 1977).

Em estudos desenvolvidos com perdizes em cativeiro no Rio Grande do Sul, MENEGHETI et al. (1985) relataram que estas aves atingem com 133 dias de idade o peso de 663 gramas. Estes mesmos autores encontraram o peso médio de 38 gramas para os pintos de um dia, nascidos através de incubação artificial. Na natureza BOKERMANN (1991), analisou o peso de 35 perdizes capturadas e obteve as médias de pesos de 803,33 g para machos e 886,41 g para fêmeas, sendo as fêmeas $10,34 \%$ mais pesadas que os machos.

CARNIO et al. (1999), observaram em seus estudos que os ovos de perdizes em cativeiro pesam em média $57,70 \mathrm{~g}$, o pinto nasce com peso médio de $38,6 \mathrm{~g}$, e as fêmeas ganham mais peso da $1^{\mathrm{a}}$ a $10^{\mathrm{a}}$ semana de vida que os machos.

Essa espécie não possui dimorfismo sexual aparente, que permita identificar claramente os machos e as fêmeas. MORO (1991) aperfeiçoou o método de sexagem por reversão da cloaca, sem a utilização de instrumentos (dilatador de narina, espéculo ou pinça de ponta romba), para verificar a presença ou não do órgão copulador, possibilitando a definição do sexo em indivíduos com apenas 7 dias de idade. Nesta faixa etária, o órgão se apresenta com aspecto vermiforme, atingindo aproximadamente $2 \mathrm{~mm}$ de comprimento por $0,2 \mathrm{~mm}$ de diâmetro.

As perdizes podem ser classificadas como onívoras, porque são capazes de consumir uma grande variedade de alimentos, a única exceção talvez seja carne putrefada. Porém, a maior quantidade de sua dieta é 
constituída de matéria vegetal, são fáceis de alimentar e bastantes flexíveis em sua dieta. A base da alimentação pode ser uma boa ração para faisões ou codornas (FOWLER, 1996).

HEMPEL (1949) analisou o conteúdo estomacal de 53 espécimes de Rhynchotus originários do estado de São Paulo, e concluiu que a maior parte da dieta destas aves era composta de matéria vegetal, consistindo principalmente de tubérculos, raízes tenras, sementes, algumas frutas, e a parte de proteína animal era composta de insetos como gafanhotos, térmitas, grilos, crisálidas, lagartas e aranhas.

\subsection{Domesticação}

A domesticação de animais é descrita por HALE (1969) como um evento recente na história da humanidade, mesmo com as espécies domésticas mais comuns estando próximas do Homem desde os tempos pré-históricos, sendo definida pelas condições onde a criação, cuidado e alimentação dos animais é mais ou menos controlada pelo Homem.

O Homem domesticou várias espécies animais (boi, cavalo, cachorro, etc.), para as mais diversas finalidades, como criação comercial, guarda, transporte, esporte, hobby e companhia, porém, a criação comercial é a que possui um maior número de espécies domesticadas até hoje (FRASER et al., 2000), muito provavelmente devido às questões geográficas e/ou à distribuição das espécies, além da incessante busca por novas fontes de energia, visando uma maior diversidade e, aumentando assim, sua importância econômica.

Neste sentido, domesticação pode ser vista como um processo evolutivo e um fenômeno experimental. Um fenótipo domesticado se refere a uma combinação de características que capacitam um animal a adaptar-se ao homem e ao ambiente cativo oferecido àquela espécie (PRICE, 1984). 
Embora as relações entre o comportamento de animais domésticos e selvagens estejam permanentemente em desenvolvimento, pode-se considerar que os animais de produção conservam os processos fundamentais de conduta que evoluíram de seus predecessores, visto serem as mudanças oriundas da domesticação mais quantitativas que qualitativas, reforçando a idéia de DARWIN, que no século XVIII já sugeria que domesticar um animal era mais que apenas amansá-lo, mas também procriá-lo em cativeiro. RATNER \& BOICE (1975) reconhecem as mudanças genéticas e a influência do cativeiro como causas fundamentais no desenvolvimento do fenótipo do animal domesticado.

A adaptação ao cativeiro é alcançada através da combinação de mudanças genéticas através de gerações e de experiências proprioceptivas calcadas no ambiente durante a vida dos animais. $\mathrm{Na}$ introdução ao cativeiro, ignorar a fase de adaptação pode causar situações de estresse, que é um efeito ambiental no indivíduo, o qual em altas taxas reduz sua aptidão e seus sistemas de controle (FRASER \& BROOM, 1997), ou seja, é considerado como uma reação fisiológica onde o animal mantém ou restabelece seu metabolismo normal frente a agentes externos.

DIAMOND $(1994)^{1}$ relacionou algumas causas como a dieta do animal, a taxa de crescimento, hábitos de acasalamento, disposição ao cativeiro, tendência ao pânico, e organização social como determinantes para esclarecer o porquê de poucas espécies animais terem sido domesticadas com sucesso.

Pelo constatado na revisão sobre a espécie em questão, observa-se que estes animais possuem características favoráveis para que sua domesticação tenha sucesso.

\footnotetext{
${ }^{1}$ DIAMOND, 1994. In: Análise dos ritmos diários de atividade de paca, CROMBERG, V. U. (manuscrito)
} 


\subsection{Bem Estar}

As técnicas de criação como um processo de adaptação a uma condição artificial (cativeiro), implica muitas vezes em negligência às necessidades básicas dos animais e desconsideração do repertório comportamental dos mesmos. A preocupação com o Bem Estar animal inaugurou novas linhas de estudo que levaram à obtenção de conhecimentos mais profundos sobre os mesmos, com pesquisas que podem fazer muita diferença num processo produtivo. Levando-se em consideração que o cativeiro, condição para a produção em escala de produtos ou subprodutos de origem animal pode levar os animais a situações de desconforto, induzindo-os ao estresse, com manifestações através de comportamentos de medo e/ou agressão. $O$ fato dos animais em cativeiro serem mantidos em grupos maiores do que quando em situação de natureza, os induzem a um excesso de interações sociais (FRANÇOIS et al., 1998).

PARANHOS DA COSTA \& CROMBERG (2001) citam que os animais possuem sistemas funcionais de controle que atuam na manutenção do equilíbrio do organismo, mantendo estável por exemplo, a temperatura corporal, o balanço hídrico e as interações sociais. As constantes estimulações do meio agindo sobre os animais acionam esses sistemas, levando-os a buscar os recursos e os estímulos necessários para a manutenção de seu controle.

\subsection{Sistemas de Acasalamento}

O conjunto de estratégias e interações sociais que ocorrem entre os indivíduos de uma população e formam um contexto dentro do qual tem lugar a união de gametas se denomina sistema de acasalamento (CARRANZA, 1994), dinamicamente, o acasalamento é a acepção de duas fases sucessivas na reprodução, o pareamento e a cópula. Pode haver 
ainda uma terceira fase: a corte nupcial que se situa cronologicamente entre as duas já mencionadas (DAVIS, 1955).

Acredita-se que os sistemas de acasalamento dos vertebrados reflitam a competitividade por recursos, tais como a distribuição de alimento, os locais de reprodução e os parceiros em potencial. Estes recursos afetam diretamente os indivíduos dos dois sexos; alguns tipos desta distribuição dão a um dos sexos a oportunidade de possuir múltiplos acasalamentos, pelo controle de acesso a esses recursos (EMLEN \& ORING, 1977; ORING, 1982). CARNIO (1993) verificou fertilidade de 49,26\%, nascimento de $25,7 \%$ e eclodibilidade de 52,13\% realizando incubação artificial de ovos de perdizes, no período de 26 de agosto de 1991 a 30 de março de 1992, de um total de 475 ovos. Estes dados se contrapõem aos obtidos por BUMP \& BUMP (1969) que observou $94,7 \%$ de fertilidade de ovos de perdizes em natureza. Quando incubados artificialmente a eclodibilidade é de $88 \%$, já CRAVINO (s.d.) não conseguiu repetir estes resultados em cativeiro, obtendo eclosão que variou entre 35 e $70 \%$.

Os vertebrados sociais exibem uma das duas grandes categorias de sistema de acasalamento - monogamia ou poligamia. A monogamia referese a uma ligação de parceiros, entre um macho e uma única fêmea. O casal pode permanecer junto parte de uma estação reprodutiva, uma estação inteira ou por toda vida. A poligamia refere-se a uma situação na qual um indivíduo tem mais de um parceiro na estação reprodutiva

A monogamia é o sistema de acasalamento dominante entre as aves, mais de 90\% (DEL HOYO et al., 1992). Nos sistemas de acasalamento monogâmicos ambos os pais participam normalmente dos cuidados com os filhotes; entre as espécies de aves monogâmicas 93\% produzem filhotes altriciais (que demandam extenso cuidado parental). 
A poligamia pode ser exibida pelos machos ou pelas fêmeas. $\mathrm{Na}$ poliginia um macho acasala-se com mais de uma fêmea, enquanto que na poliandria uma fêmea acasala-se com dois ou mais machos, um tipo menos freqüente de poligamia, onde as fêmeas após acasalar-se abandonam os machos e estes passam a cuidar dos ovos e filhotes (DEL HOYO et al., 1992).

A promiscuidade é o segundo sistema de acasalamento mais comum entre as aves, sendo uma mistura de poliginia e poliandria, na qual, ambos, machos e fêmeas acasalam-se com vários indivíduos diferentes. Apesar de sua relativa raridade, as espécies de aves promíscuas, poligínicas e poliândricas têm sido bastante estudadas, pois se espera que estes sistemas de acasalamento pouco usuais, possam revelar muito acerca dos mecanismos de evolução e seleção sexual (POUGH et al., 1999).

Alguns fatores do meio ambiente, por exemplo, recursos disponíveis, são os responsáveis pelo grau em que os indivíduos de um sexo podem monopolizar os de outro, frente aos rivais do próprio sexo, o que para ORIANS (1969) e EMLEN \& ORING (1977) é o mesmo que dizer do potencial do meio para a poligamia.

A inversão de funções sexuais não determina que o sistema seja poliândrico, é a pré-adaptação óbvia para a evolução da poliandria simultânea e seqüencial (FAABORG \& PATTERSON, 1981), onde a monogamia teria evoluído para a monogamia de dupla postura. Este tipo de acasalamento ocorre em momentos de abundância de alimento ou quando há falha na nidificação e significa que a fêmea emancipada da incubação que ficaria a cargo do macho, tem a oportunidade de fazer uma segunda postura, a qual incubará. Esta monogamia duplica o esforço reprodutivo do macho e da fêmea. A evolução prosseguiria até a poliandria seqüencial que significa que a fêmea copula com dois ou mais machos em sucessão e põe um conjunto de ovos. Desta poliandria haveria duas opções no caminho 
evolutivo: a poliandria simultânea e a poligamia múltipla de rápida postura. $\mathrm{Na}$ poliandria simultânea, a fêmea copula com vários machos simultaneamente e forma uma associação estável durante o processo de reprodução. Na poligamia múltipla de rápida postura, como descrito para algumas espécies de Tinamídeos, após a deserção da fêmea o macho pode retardar a incubação e permanecer sexualmente ativo, atraindo uma segunda companheira e tornando-se poligínico. A fêmea, por sua vez é poliândrica.

Apesar das dificuldades encontradas para se diferenciar os Sistemas de Acasalamento, ORIANS (1969) reconhece que há evidência de poliandria em cinco grupos taxonômicos, entre eles os Tinamidae, fato observado também por PIANKA (1974) que relata que ocorrem em algumas espécies de Jacanidae, Tinamidae e Rallidae. Todos estes grupos têm ao menos uma característica em comum: possuem jovens com um alto grau de independência em sua atividade desde o nascimento.

Para vários autores a poliandria é um sistema de acasalamento vantajoso por ter maior potencial reprodutivo. ORIANS (1969); BUMP \& BUMP (1969) afirmam que a fêmea presumivelmente aumenta sua resposta reprodutiva se vários machos puderem ser induzidos a cuidar de seus ovos e filhotes, nesta situação a posição dos machos será desvantajosa, apesar de dentro da poliandria, normalmente serem os machos que se beneficiam, ao aumentarem o número de fêmeas com que se acasalam (CARRANZA, 1994).

Uma clara relação entre os sistemas de acasalamento e as variedades de dimorfismo sexual nas aves pode ser percebida (DEL HOYO, 1992). Em espécies monogâmicas os parceiros de sexos diferentes são normalmente semelhantes em tamanho e cor, e geralmente os papéis desempenhados por machos e fêmeas durante o cortejo são também comparáveis. Reciprocamente, quase todas as espécies poligâmicas 
apresentam dimorfismo, com um ou outro parceiro, sendo maiores e de cores mais intensas, invariavelmente os machos em espécie poligínicas, e as fêmeas em espécies poliândricas. Este é o resultado previsível de seleção sexual claramente imposto por estes sistemas de acasalamento.

Os Tinamídeos na América do Sul despertam interesse a algum tempo, em 1936 LIEBERMANN já citava que os Tinamídeos na Argentina eram predominantemente poliândricos, sistema de acasalamento depois confirmado por ORIANS (1969), que observou entre os tinamídeos a denominada inversão dos papéis que cada sexo costuma desempenhar, que SICK (1997) descreve como indivíduos de tinamídeos mudando de comportamento de acasalamento com a idade, onde por exemplo, um macho de um tinamídeo andino apresentou-se como monógamo quando jovem e polígamo ao se tornar mais velho.

No sistema de acasalamento em Rhynchotus rufescens tem sido relatado um nítido aumento de reprodução pelo hábito da fêmea em acasalar-se com diferentes machos, sucessivamente, e a aceitação por parte do macho em incubar e cuidar da prole. Esta isenção da incubação e do cuidado da prole, permite a fêmea reduzir o tempo necessário entre duas posturas sucessivas, devido à recuperação mais rápida de energias gastas durante um período de reprodução (MENEGHETI \& MARQUES, 1981). Ao referir-se a Rhynchotus rufescens, LIEBERMAN (1936) considera a poliandria como uma adaptação eficiente à reprodução rápida num curto período, já que mais de uma fêmea faria postura num mesmo ninho. Assim, mais rapidamente é atingido um número mínimo de ovos normalmente observados nos ninhos. A incubação se iniciaria mais rapidamente e, desta forma, os ninhos ficariam menos expostos a riscos.

A grande fecundidade e a poliandria estão relacionadas com a vida terrícola, além de ser uma defesa biológica contra os numerosos inimigos que as atacam. SICK (1997) também cita a eficiência do sistema de 
reprodução desta família, que pode ser comprovado pela abundância destas aves em áreas virgens ou quando não são perseguidas. Afirmando também que a poliandria é o caminho mais certo para uma multiplicação mais rápida.

Apesar das definições dos diferentes sistemas de acasalamento quanto aos hábitos sociais nota-se que há alguns Tinamídeos como por exemplo em Nothura maculosa, que apesar de ser considerada como uma espécie de hábitos solitários (SERIÉ \& SMITH, 1923; HUDSON, 1928; LIEBERMAN, 1936; BUMP \& BUMP, 1969), durante o período de reprodução encontramos pares de indivíduos (MENEGHETI, 1981), podendo estas observações ser utilizadas para se definir o período e a intensidade com que se dão os acasalamentos. Outras espécies de Tinamídeos podem apresentar comportamentos de grupo em época não reprodutiva, como é o caso de Eudromia elegans multiguttata (GALLARDO, 1984).

Quanto à duração do período reprodutivo para Nothura maculosa, MENEGHETI (1981) observou que se inicia em pleno inverno e início da primavera, concluindo que o acasalamento se percebe durante pelo menos 9 meses, atingindo sua maior intensidade no início do processo, entre agosto e setembro; enquanto BURGER (1991) demonstrou uma reprodução marcadamente estacional, com início em setembro e final em fevereiro e março, as fêmeas apresentaram uma rápida subida na curva de reprodução em setembro, dois meses de plena reprodução, outubro e novembro, e uma descida de dois a três meses, janeiro (provável), fevereiro e março. $O$ autor ainda sugere que os acasalamentos do outono não se consumam com o mesmo sucesso do que os verificados no fim do inverno e início da primavera. 


\subsection{Dominância}

Pode-se observar nos vertebrados mais simples (por exemplo nas aves) certa organização social, que pode ser vista na migração e nos bandos (DETHIER \& STELLAR, 1988).

Freqüentemente identifica-se um determinado indivíduo como sendo o animal dominante, que é o animal que ocupa o topo da hierarquia, sendo também chamado de animal alfa. Algumas aves mostram uma ordem de bicar, na qual a ave dominante bica a ave submissa. Desta forma pode-se dizer que se estabeleceu entre os animais uma relação dominantesubordinado. Nesse caso, ou se teria desenvolvido o reconhecimento individual ou então os animais teriam aprendido as características gerais de animais que eles conseguem ou não dominar. As relações assim estabelecidas formam uma hierarquia, com cada animal bicando aqueles que estão abaixo dele na hierarquia, e evitando os que estão acima, embora haja exceções.

Para cada um dos indivíduos de um grupo há a caracterização de um espaço individual, representado pela área onde o animal se encontra e, portanto, se desloca com ele. Esse espaço compreende o espaço físico que o animal necessita para realizar os seus movimentos básicos, e um espaço social, que caracteriza a distância mínima estabelecida entre um animal e os demais membros do grupo. Além disso, existe a distância de fuga, que é a distância que um animal tolera sem a presença de um estranho ou do predador, antes de iniciar a fuga (Figura 3). Tais padrões de espaçamento não são suficientes para a neutralização ou diminuição da agressividade entre animais que estão competindo por algum recurso. Outro mecanismo de controle social, que tem origem na familiaridade e na competição entre eles, resulta na definição da liderança e da hierarquia de dominância, respectivamente (PARANHOS DA COSTA \& CROMBERG, 2001). 


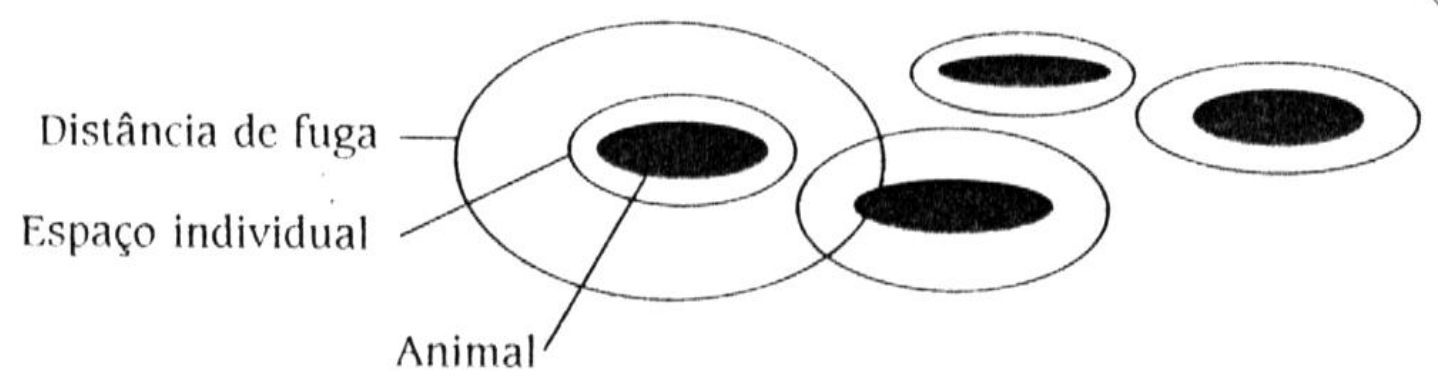

FIGURA - 3. Esquema ilustrativo do espaço individual e a distância de fuga nos animais, as diferenças apresentadas no desenho representam a existência de diferenças individuais (PARANHOS DA COSTA \& CROMBERG, 2001).

Relações de dominância e submissão semelhantes determinam não apenas o tipo de organização social possível, mas também algumas das conseqüências daquela organização para a saúde dos indivíduos, bem como o tamanho das populações animais (DETHIER \& STELLAR, 1988).

\section{MATERIAL E MÉTODOS}

\subsection{Animais}

As observações foram realizadas em Janeiro/2001, dentro da época reprodutiva 2000/2001, onde 18 animais da espécie Rhynchotus rufescens, aptos à reprodução foram alojados em boxes com três animais (1 macho e 2 fêmeas) cada, quando se escolheu aleatoriamente dois destes boxes para se fazer as observações. As aves tiveram marcações distintas feitas com esmalte em suas penas.

\subsection{Instalações}

As aves foram alojadas no Galpão Experimental de Perdizes do Campus da USP de Pirassununga, que mede $30 \times 7 \mathrm{~m}$, tem piso de concreto e 32 boxes de $2,5 \times 1,6 \mathrm{~m}$. Os boxes são separados entre si por muretas de alvenaria de $0,6 \mathrm{~m}$ de altura e completadas com tela até $2 \mathrm{~m}$. Externamente $o$ 
galpão possui cortina plástica, com movimentação feita através de catraca, a qual foi mantida totalmente aberta durante o experimento.

\subsection{Manejo}

Cada box possui um comedouro tipo linear colocado na parede lateral e um bebedouro automático do tipo pendular, assim como cama de feno de gramínea do tipo "coast- cross". O manejo das aves foi diário, consistindo no fornecimento de ração e água "ad libitum", sempre pelo período da manhã (antes do início das filmagens), a fim de não causar interferências no registro do comportamento das aves.

\subsection{Coleta de Dados}

A coleta de dados de cada lote foi feita através de filmagem durante 12 horas ininterruptas, do amanhecer ao entardecer, durante três dias consecutivos, totalizando 36 horas de filmagens, a câmera filmadora marca SHARP Slimcam modelo VL-L62U, com fitas VHS, foi posicionada no corredor externo em frente ao box para captura das imagens, cujas fitas foram trocadas a cada duas horas, procurando evitar a interferência no box que estava sendo filmado.

O material resultante das filmagens foi observado para obtenção da série de dados utilizados para as análises temporais, utilizando-se o sistema de amostragem temporal (time sampling) para a observação dos comportamentos das aves (ALTMANN, 1974; MARTIN \& BATESON, 1986). As gravações das filmagens foram analisadas na proporção de 30 segundos analisados para cada intervalo de cinco minutos de filmagens. As observações foram registradas em planilhas confeccionadas a partir das categorias comportamentais, conforme indicadas no etograma, onde registrou-se a categoria comportamental e o horário em que o animal a manifestou. Para as análises seqüenciais e de freqüências absolutas, observou-se 20 minutos, distribuídos entre o período da manhã, início e final 
da tarde, durante os três dias de experimento, para cada animal, em cada box.

\subsection{Etograma de Trabalho}

Levando-se em consideração a observação prévia feita nos animais a serem estudados, conforme proposto por MARTIN e BATESON (1986), e a descrição comportamental realizada por WEEKS (1973), foi confeccionado um etograma dos padrões comportamentais na situação acima descrita: Deslocamento (DE) - o animal, com o corpo ereto, desloca-se pelo recinto, colocando uma perna à frente da outra e assim impulsionando seu corpo e se deslocando (caminhando ou correndo).

- Parado (PA) - o animal apresenta imobilidade em posição ereta ao menos por 5 segundos.

- Sentado Parado (SP) - o animal apresenta imobilidade em posição sentada sobre seus tarsos ao menos por 5 segundos.

- Sentado Ativo (SA) - o animal deixa de deslocar-se ao menos por 5 segundos, mantendo-se em posição sentada, remexendo a cama que forra o box, ciscando o chão ao seu redor ou remexendo suas penas.

- Comer (C) - o animal, em frente ao cocho inclina a cabeça e apreende partículas de ração com o bico.

- Beber $(\mathrm{BE})$ - o animal pára em frente ao bebedouro inclina-se e bica o bebedouro.

- Agredir (AG) - o animal ao se aproximar ou quando da aproximação de outro desfere bicadas.

- Apanhar (AP) - o animal que é alvo das bicadas passa a ser agredido por outro através de bicadas.

- Ameaçar (AM) - o animal dirige ou arremessa sua cabeça em direção ao outro, ou persegue-o.

- Evitar (EV) - um animal parado ou em deslocamento, com a aproximação de outro muda sua direção, assim evitando-o. 
- Ciscar (CS) - o animal com o uso do bico ou do pé remexe ou bica a cobertura do solo do recinto.

- Arrumação (AR) - o animal remexe suas penas com o bico.

- Esticar (ES) - o animal estica a perna e a asa do lado direito ou do lado esquerdo.

- Subir (SU) - o animal sobe em cima de outro.

- Eriçar (ER) - eriça a plumagem junto com tremor lateral e movimentos semicirculares do corpo.

- Banho de Pó (BP) - enquanto caminha, ou se levanta ocasionalmente, a ave pode fazer movimentos abaixando seu corpo e bicando obliquamente $o$ chão. O pássaro pode então endireitar o corpo e continuar a caminhar, ou ele pode girar e se sentar muito próximo à área bicada. Nesta posição o pássaro continua a bicar a cama à frente de seu peito e uma ou outra bicada para a lateral, sempre jogando o material da cama sobre seu corpo.

Para avaliar como as perdizes observadas distribuiam suas principais categorias de atividade ao longo do dia, aplicamos o procedimento de análise espectral às séries de dados. Os animais foram filmados do amanhecer ao anoitecer, isto devido a observações preliminares que indicavam que os mesmos permanecem imóveis durante o período noturno, confirmando observações de POUGH et al. (1999), que afirma que as aves têm por característica a diurnalidade, ou seja, a maioria das aves é ativa somente durante o dia.

\subsection{Análises Estatísticas}

Foram construídas séries temporais, uma para cada categoria para o período analisado, perfazendo um total de 864 pontos por série (três dias * 12 medidas por hora). As séries temporais foram submetidas à análise espectral, através da Análise de Fourrier; este matemático francês mostrou em 1822, que quase qualquer função periódica pode ser representada, com diferentes graus de aproximação, por uma série constituída de funções seno 
e coseno. A análise espectral de séries temporais compreende técnicas estatísticas para a detecção e a avaliação da significância estatística da variação periódica de uma série de dados (LEGENDRE \& LEGENDRE, 2000).

\section{As Árvores Orientadas}

A obtenção das árvores orientadas seguiu a metodologia descrita no Anexo A. A interpretação destes diagramas está apresentada junto aos resultados pois acreditamos ser mais fácil compreende-las através dos exemplos utilizados para analisarmos a organização estrutural dos comportamentos de machos e fêmeas de perdizes.

\section{Qui-Quadrado (X²)}

Utilizou-se o teste do Qui-Quadrado para comparar-se as médias obtidas dos comportamentos das perdizes conforme as categorias propostas no Etograma de Trabalho, com a aplicação deste teste obteve-se quais animais eram significativamente semelhantes entre si, entre os sexos e entre os diferentes boxes (para uma revisão ver BEIGUELMAN, 1996).

\section{Teste-t para amostras dependentes}

O teste-t foi utilizado para se visualizar semelhanças individuais entre as perdizes, conforme as categorias propostas no Etograma de Trabalho, através das porcentagens de freqüência média de ocorrência destes comportamentos observados das 06:55 às 19:50 horas, para os seis animais nas três repetições (para uma revisão ver BEIGUELMANN, 1996). 


\section{RESULTADOS}

\subsection{Distribuição Freqüencial do Repertório Comportamental}

Os comportamentos observados tiveram sua freqüência analisada individualmente por animal. A Tabela 1 permite visualizar estes resultados, entretanto, as categorias arrumar (AR) e ciscar (CS) estão ligeiramente subavaliadas, pois na categoria sentado ativo (SA) poderia estar ocorrendo um destes dois comportamentos. Outro ponto a salientar é que os números apresentados para as freqüências médias das categorias estão arredondados, desta forma o único zero (0) absoluto ocorre para a fêmea 3 na categoria banho de pó (BP).

Vale ressaltar ainda que, quando se observou a categoria comportamental subir (SU), não se avaliou a existência ou não de cópula, podendo muitas vezes um animal de qualquer sexo "subir ou ser montado" por outro. No entanto, a baixa freqüência desta categoria comportamental surpreendeu, uma vez que se estava em plena época de acasalamento, principalmente entre sexos opostos (uma única ocorrência). 
TABELA 1 - Porcentagem de freqüência média de ocorrência dos comportamentos observados das 6:55 h. às 19:50 h. para os seis animais em 3 repetições, com valores arredondados. As letras indicam semelhanças significativas $\mathrm{p}<0.05$ (teste-t).

\begin{tabular}{c|c|c|c|c|c|c|c}
\hline \multicolumn{2}{c|}{ CATEGORIA } & fêmea 1 & fêmea 2 & fêmea 3 & fêmea 4 & macho 1 & macho 2 \\
\hline DE & Deslocam/to & $29 b$ & $32 a b$ & 9 & 26 & $34 a$ & $32 a b$ \\
\hline PA & Parado & 15 & $11 b$ & 2 & $11 b$ & $7 a$ & $9 a$ \\
\hline SP & $\begin{array}{c}\text { Sentado } \\
\text { imóvel }\end{array}$ & $4^{a}$ & $3 a$ & 62 & $7 b$ & $6 b$ & 18 \\
\hline SA & Sentado ativo & $3^{a}$ & $4 a$ & $4 a$ & $3 a$ & $2 a$ & $3 a$ \\
\hline CO & Comer & $15^{a}$ & $13 a$ & 10 & $15 a$ & 18 & $15 a$ \\
\hline BE & Beber & $1 b$ & $3 a$ & $1 b$ & 0 & $3 a$ & $1 b$ \\
\hline AG & Agressão & $1^{a}$ & 2 & $0 b$ & $0 b$ & $0 b$ & $1 a$ \\
\hline AP & Apanhar & $1 a$ & $1 a$ & $0 b$ & $0 b$ & $0 b$ & $1 a$ \\
\hline AM & Ameaçar & $0 a$ & 2 & $0 a$ & $0 a$ & $0 a$ & $0 a$ \\
\hline CS & Ciscar & 21 & 17 & 4 & $10 a$ & 14 & $11 a$ \\
\hline AR & Arrumar & $6 a$ & 10 & $8 a$ & 22 & 13 & $8 a$ \\
\hline ES & Esticar & $0 a$ & $0 a$ & $0 a$ & $1 a$ & $0 a$ & $0 a$ \\
\hline SU & Subir & $1 a$ & $2 a$ & $0 a$ & $0 a$ & $0 a$ & $1 a$ \\
\hline ER & Eriçar & $0 a$ & $1 a$ & $0 a$ & 3 & $2 a$ & $0 a$ \\
\hline CÇ & Coçar & $1 a$ & $2 a$ & $0 a$ & $1 a$ & $1 a$ & $1 a$ \\
\hline BP & Banho pó & $1 a$ & $1 a$ & $0 a$ & 3 & $1 a$ & $1 a$ \\
\hline
\end{tabular}

$\mathrm{Na}$ Tabela 1, salienta-se as diferenças freqüenciais de alguns comportamentos com relação à fêmea 3. Esta fêmea, no dia que antecedeu o início das filmagens, sofreu durante sua marcação um traumatismo na perna, apresentando apenas posteriormente, durante os dias de experimentação, problemas para se locomover. Ao invés de substituir-se este animal, com o inconveniente de ter-se que esperar por um novo período de adaptação, e ainda, devido ao fato de originalmente a quantidade de filmagens já estar limitada pelos poucos recursos disponíveis, resolveu-se manter este animal. Procedeu-se assim, a um estudo de caso através da comparação destas duas situações, isto é, a situação em que três animais sadios ocuparam um box, e aquela onde um dos três animais do outro box possuía uma lesão na perna. 
Por esta ótica, observou-se que no comportamento de deslocamento (DE) a fêmea 3 é quem exibiu a menor porcentagem freqüencial de ocorrência (9\%), contra uma variação de deslocamento de 26 a 34\% para os outros animais. Nos comportamentos que exigiram atividades associadas às posturas de ficar em pé, notou-se também para este animal as menores freqüências, como por exemplo na categoria ciscar (CS) onde se obteve $4 \%$ de freqüência contra uma variação de 10 a $21 \%$; em comer (CO) 10\% contra 13 a $18 \%$ ou ainda ficar parada em pé (PA), $2 \%$ contra 7 a $15 \%$. A fêmea 3 passou a maior parte do tempo observado em comportamento sentado imóvel, com freqüência de $62 \%$, contra uma variação para os outros animais de 3 a 18\%, conforme se pode verificar nas Figuras de 4 a 7 .

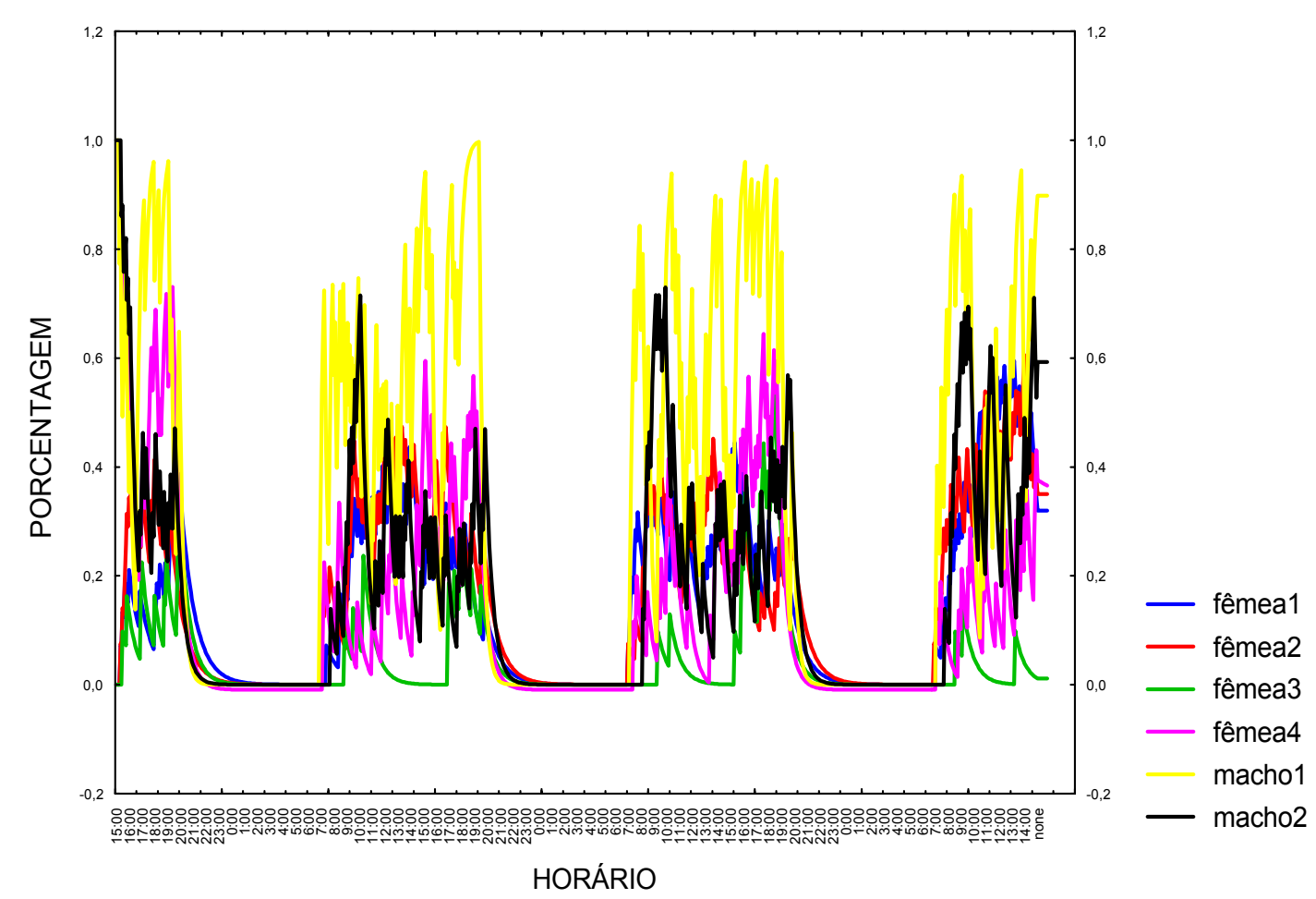

FIGURA 4 - Distribuição da porcentagem de freqüência ajustada da categoria deslocamento (DE) para os animais estudados. 


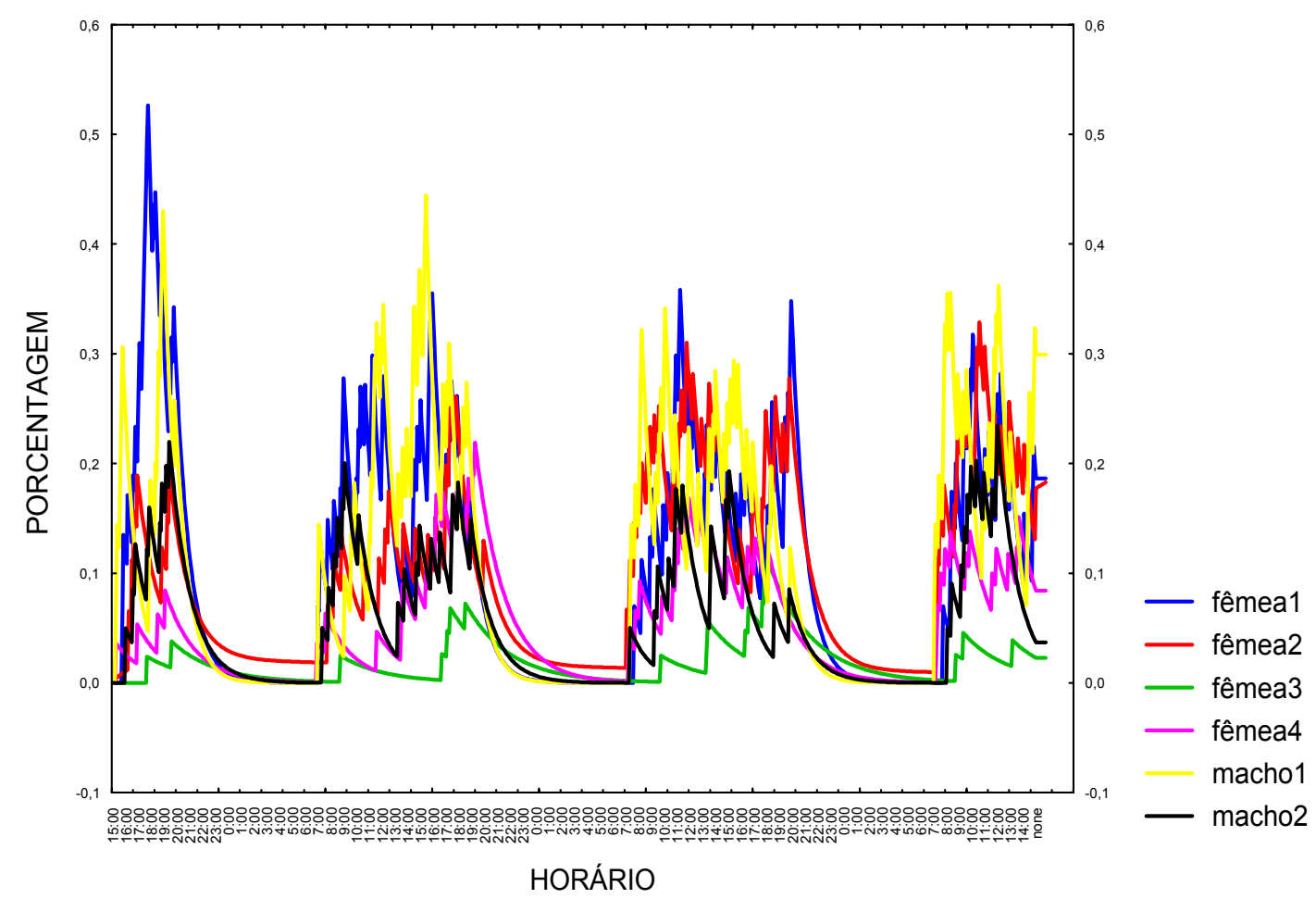

FIGURA 5 - Distribuição da porcentagem de freqüência ajustada da categoria ciscar (CS), para os animais estudados.

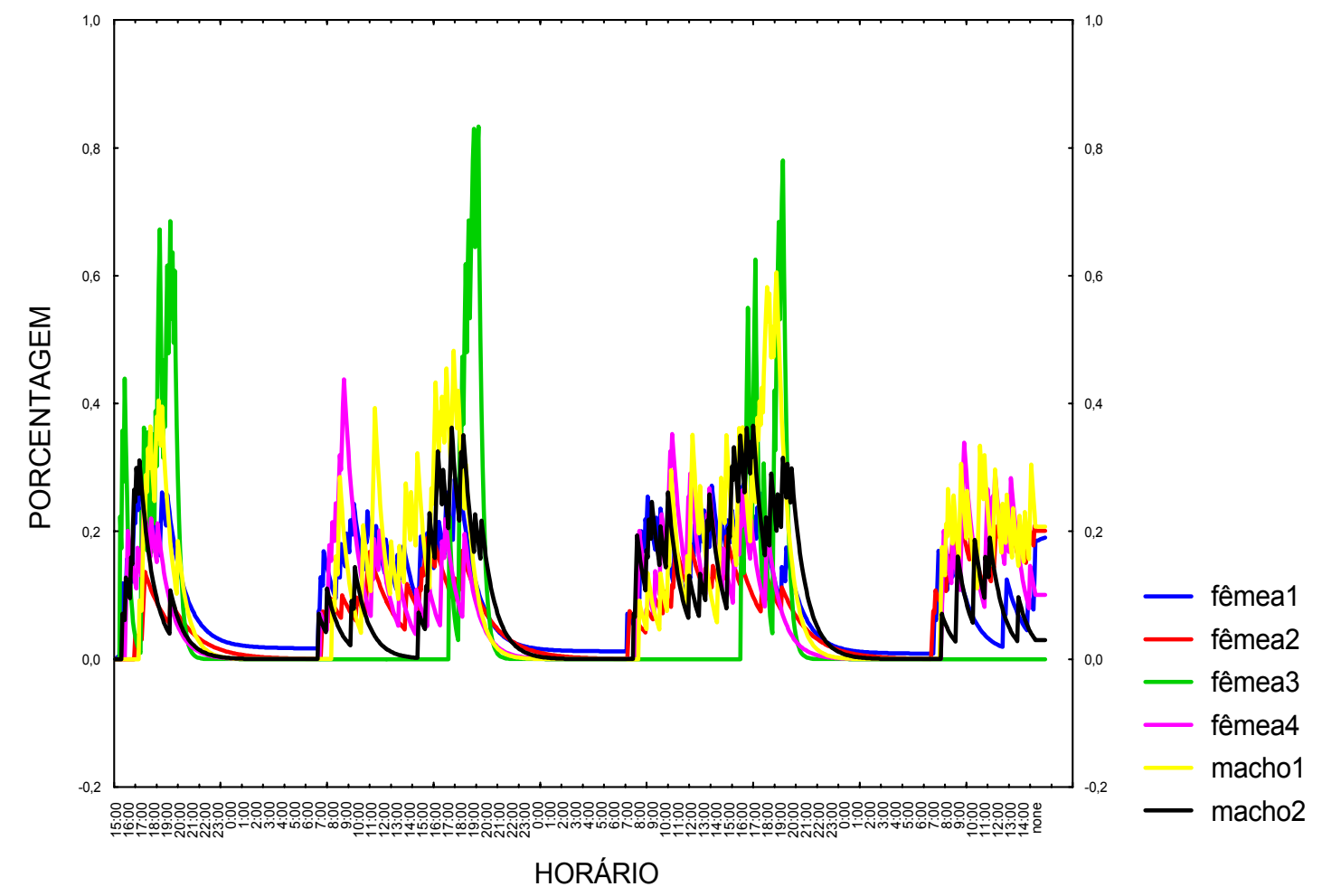

FIGURA 6 - Distribuição da porcentagem de freqüência ajustada da categoria comer (CO), para os animais estudados. 


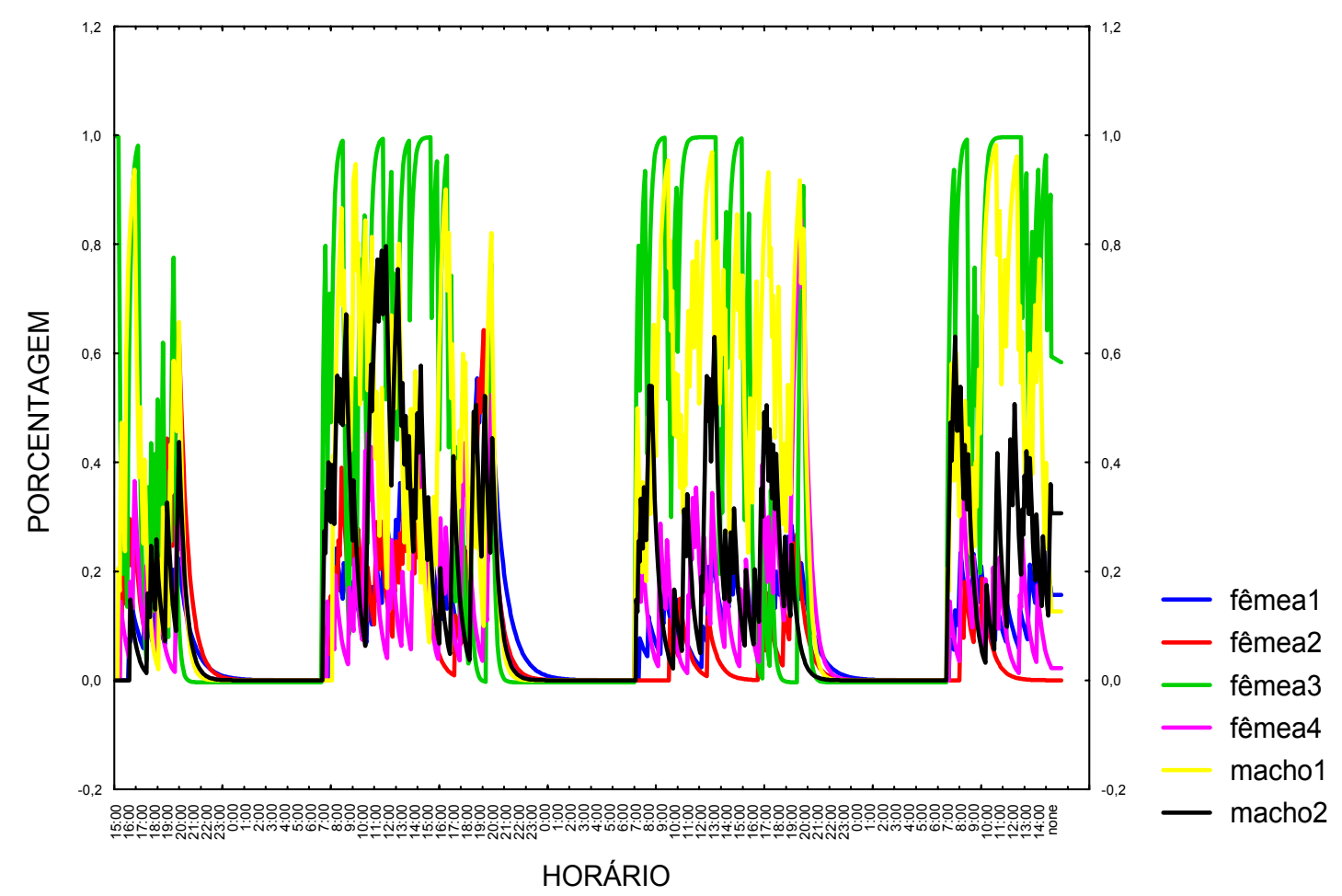

FIGURA 7 - Distribuição da porcentagem de freqüência ajustada da categoria imobilidade (IM), somatória de parado (PA) e sentado imóvel (SP), para os animais estudados.

Quando observou-se as fêmeas "sadias", notou-se que houveram poucas diferenças entre as fêmeas do box $A$ (fêmeas 1 e 2), com diferença significativa apenas para freqüências dos comportamentos de ameaçar (AM), arrumar (AR) e parado (PA). Comparando a fêmea 1 do Box A com a fêmea 4 do box $B$, encontraram-se diferenças entre as freqüências médias dos comportamentos de deslocamento (DE), parado (PA), sentado imóvel $(\mathrm{SP})$, beber (BE), arrumar (AR), eriçar (ER) e banho de pó (BP); além das diferenças entre a fêmea 2 e a fêmea 4 para deslocamento $(D E)$, sentado imóvel (SP), beber (BE), agressão (AG), apanhar (AP), ameaçar (AM), ciscar (CS), arrumar (AR), eriçar (ER) e banho de pó (BP). Percebeu-se que a fêmea 1 e a fêmea 2 apresentaram uma distribuição freqüencial para as categorias comportamentais mais semelhantes entre si do que cada uma destas e a fêmea 4. Sendo que a fêmea 2 apresentou um maior grau de diferenciação nas freqüências. 
Com relação aos machos, notou-se que entre eles as diferenças nas freqüências se deram nas categorias: sentado imóvel (SP), comer (CO), beber (BE), agressão (AG), apanhar (AP), ciscar (CS) e arrumar (AR).

As comparações entre fêmeas e machos foi prejudicada pela variabilidade individual, pois notou-se que para categorias diversas cada uma das fêmeas pode diferir dos dois ou de apenas um dos machos. Desta forma, mesmo calculando-se freqüências médias de fêmeas e machos para as comparações, não obteve-se informações válidas.

Vale a pena abrir uma exceção para a fêmea 3 em relação ao macho1, se observamos as Figuras de 4 a 7 , onde pode-se notar que há um certo padrão em suas manifestações comportamentais, ressaltando a grande diferença em suas intensidades freqüenciais, talvez pelo fato da fêmea 3 estar machucada, porém lembrando que, ambos eram dominados por outra fêmea dentro do mesmo box.

Duas situações onde comparou-se os machos com as fêmeas merecem ser destacadas. A primeira diz respeito à categoria comer (CO), notando-se que o macho 1 apresentou freqüência maior que os outros animais, esta superioridade chamou atenção por apresentar um valor muito superior aos outros, $18 \%$ versus uma variação de 10 a $15 \%$ nos outros animais. A outra situação ocorreu na categoria arrumação (AR), onde a fêmea 4 apresenta uma freqüência de $22 \%$ versus uma variação de 6 a $13 \%$.

Uma análise de correlação (Pearson) entre os animais foi executada para cada categoria comportamental mais freqüente, apesar da dificuldade de interpretação deste procedimento, uma vez que, a coincidência pela semelhança das distribuições freqüências possíveis, tornou difícil a separação da casualidade de uma dependência entre as variáveis. Desta forma, a Tabela 1 não apresenta comparação entre animais de boxes 
diferentes e, ainda assim o resultado obtido entre Boxes deve ser visto com ressalvas.

A Tabela 2 foi elaborada apenas para as categorias onde os índices de correlação foram marcadamente diferentes, mostrando que os animais que habitam o Box A mostraram correlações significativas entre si, apesar da existência de correlações muitas vezes superiores entre estes animais quando correlacionados com animais de boxes diferentes, conforme mencionado. Por outro lado, estas correlações ficaram muito abaixo dos valores obtidos entre a fêmea 4 e o macho 2 do Box $B$, que apresentaram os maiores valores de correlação entre todas as demais obtidas, dando crédito de que realmente a ligação destes animais seja digna de nota.

TABELA 2 Correlação de Pearson para os comportamentos de perdizes observados que mostraram valores significativos $(p<0,05)$.

\begin{tabular}{c|c|r|r|r}
\hline Categoria & Animal & $\mathbf{2}$ & $\mathbf{5}$ & $\mathbf{6}$ \\
\hline Arrumação & $\mathbf{1}$ & 0,13 & & 0,16 \\
\cline { 2 - 5 } AR & $\mathbf{2}$ & & & 0,1 \\
\cline { 2 - 5 } & $\mathbf{4}$ & & 0,35 & \\
\hline Comer & $\mathbf{1}$ & & & 0,13 \\
\cline { 2 - 5 } CO & $\mathbf{4}$ & & 0,24 & \\
\hline Deslocamento & $\mathbf{1}$ & 0,24 & & 0,27 \\
\cline { 2 - 5 } DE & $\mathbf{2}$ & & & 0,22 \\
\cline { 2 - 5 } & $\mathbf{4}$ & & 0,49 & \\
\hline Sentado inativo & $\mathbf{1}$ & 0,23 & & 0,11 \\
\cline { 2 - 5 } & $\mathbf{2}$ & & & 0,11 \\
\cline { 2 - 5 } SP & $\mathbf{4}$ & & 0,37 & \\
\hline
\end{tabular}

Tentando obter uma visualização mais fácil das diferenças entre os boxes, agrupou-se os animais que habitavam cada um destes, ignorando as freqüências da fêmea 3. A Tabela 3 mostra os resultados das análises 
das freqüências médias das categorias comportamentais mais importantes, assim obtidas e testadas quanto à significância pelo teste-t.

TABELA 3 - Porcentagem de freqüências médias de ocorrência dos comportamentos mais significativos, observados das 6:55 h. às 19:50 h. para os animais agrupados por box. Valores arredondados.

\begin{tabular}{l|l|l}
\hline Comportamento & Total Box A & Total Box B \\
\hline Parado (PA) & 12 & 15 \\
\hline $\begin{array}{l}\text { Sentado Inativo } \\
(\mathrm{SP})\end{array}$ & $9 \mathrm{a}$ & $9 \mathrm{a}$ \\
\hline Deslocamento (DE) & $31 \mathrm{a}$ & $31 \mathrm{a}$ \\
\hline Arrumação (AR) & 8 & 19 \\
\hline Comer (CO) & 14 & 18 \\
\hline Ciscar (CS) & $16 a$ & $16 a$ \\
\hline As letras indicam semelhanças significativas, $\mathrm{p}<0.05$ (teste-t).
\end{tabular}

Os boxes diferiram quanto às freqüências nas categorias parado (PA), arrumação (AR) e comer (CO), entre aquelas testadas, sendo que as maiores porcentagens freqüenciais ocorreram no box $B$.

Ao analisarmos a arrumação (AR), Figuras 8 e 9, pode-se notar que há diferença na freqüência desta categoria em ambos os boxes, uma vez que visualiza-se a existência de diferenças na distribuição da freqüência deste comportamento entre os animais de ambos os boxes. 


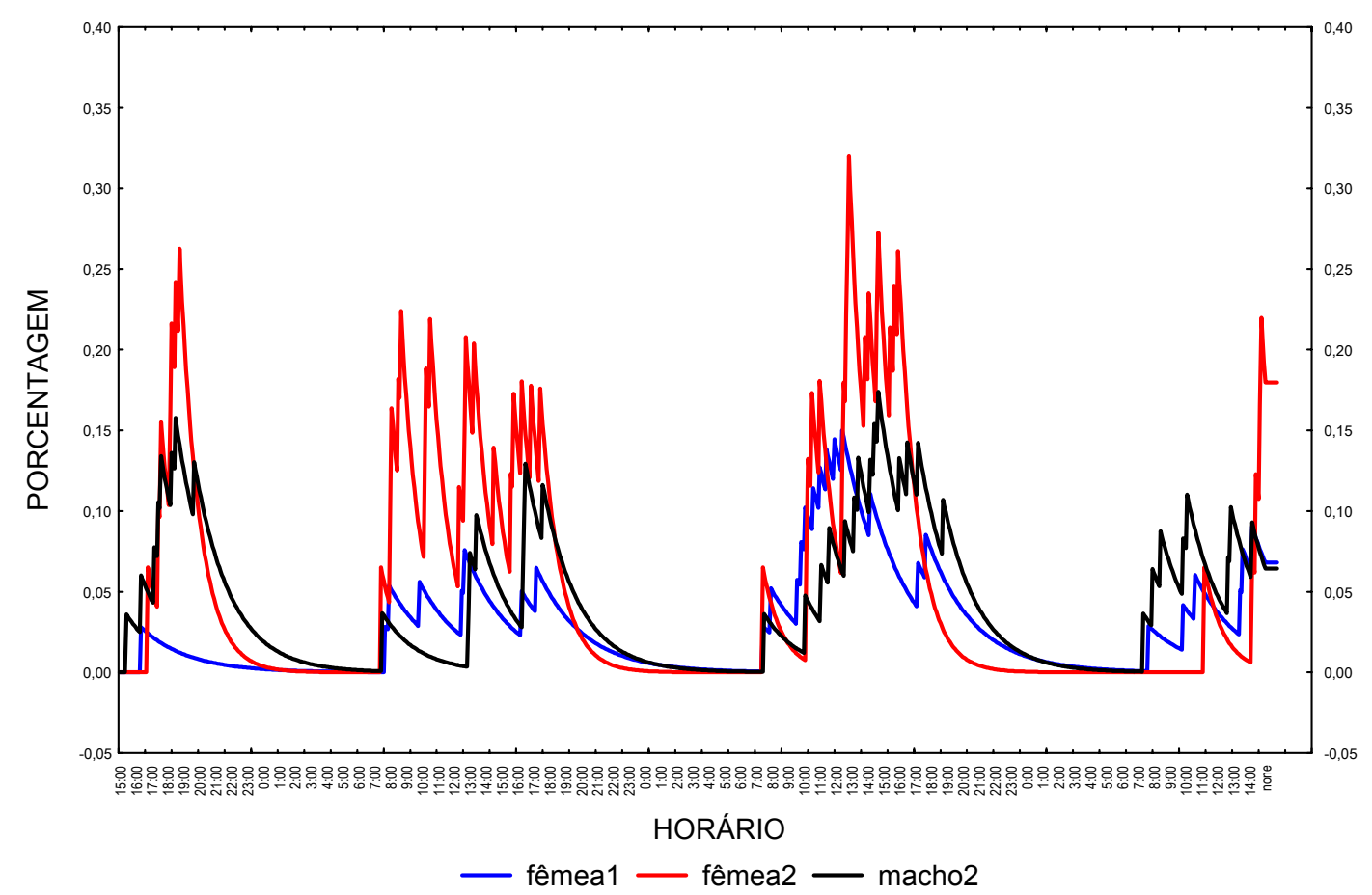

FIGURA 8 - Porcentagem da freqüência da categoria arrumação (AR) dos animais do box $A$.

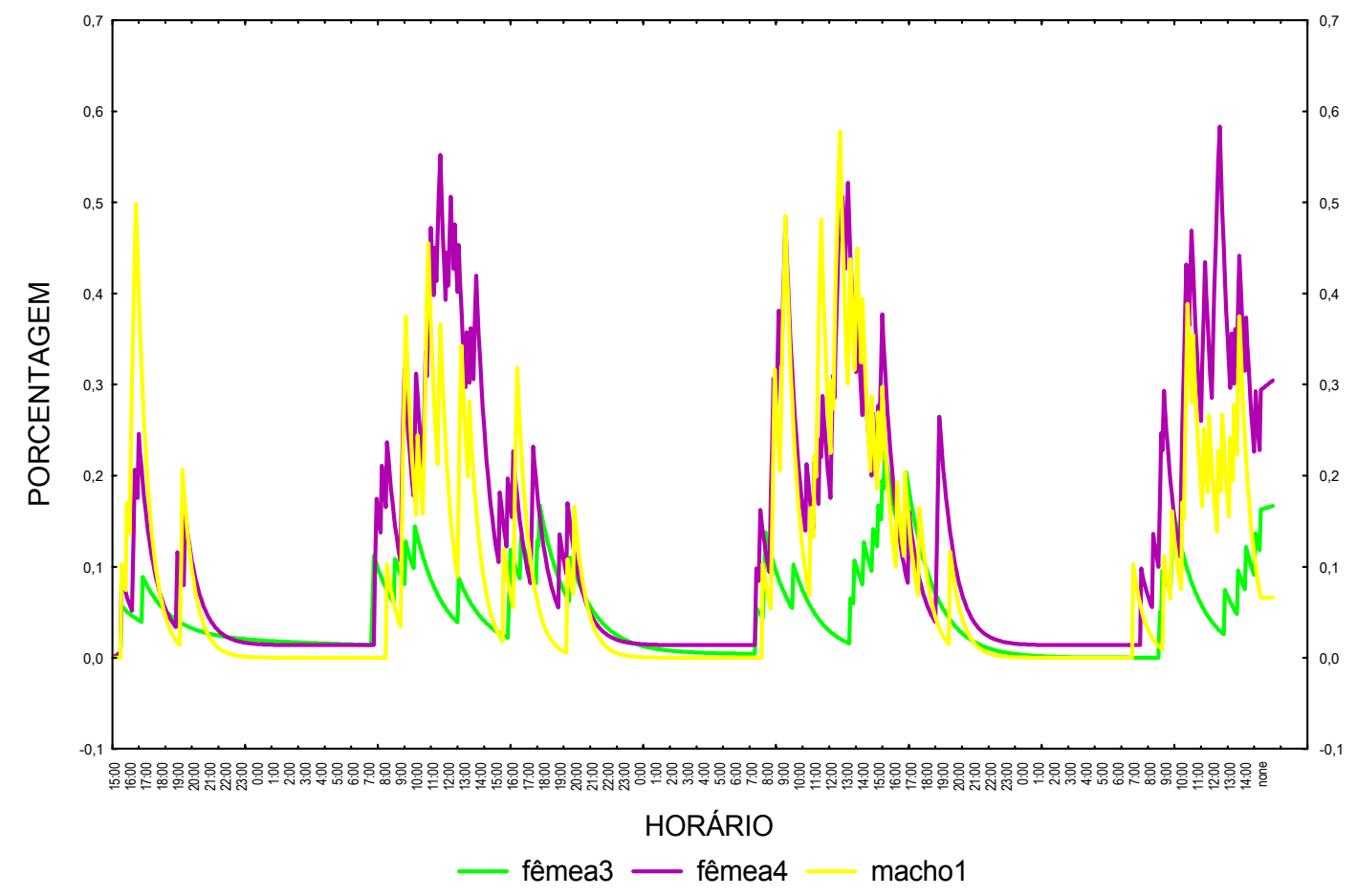

FIGURA 9 - Porcentagem da freqüência da categoria arrumação (AR) dos animais do box $B$. 
Quando observa-se as Figuras 10 e 11 que representam o comportamento comer ( $\mathrm{CO}$ ) nos boxes $\mathrm{A}$ e $\mathrm{B}$, nota-se que a freqüência desta categoria tem picos freqüenciais maiores ao entardecer para a fêmea 3 , assim como para os machos 1 e 2 , a fêmea 4 apresentou picos maiores no período da manhã, as fêmeas 1 e 2 se alimentaram ao longo do dia, demonstrando assim que não há uma homogeneidade para este comportamento entre os animais dos boxes.

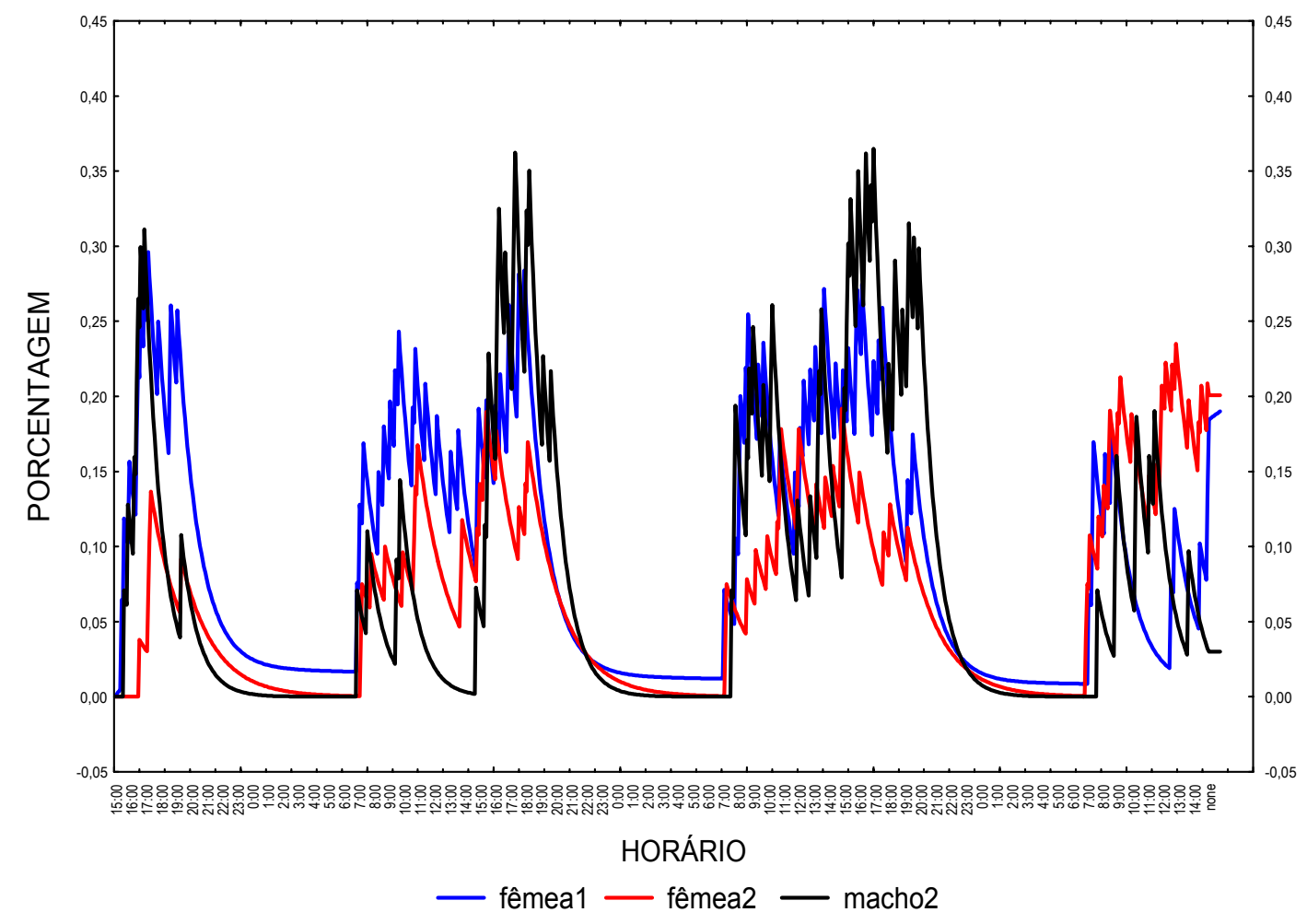

FIGURA 10 - Porcentagem da freqüência da categoria comer (CO) dos animais do box A. 


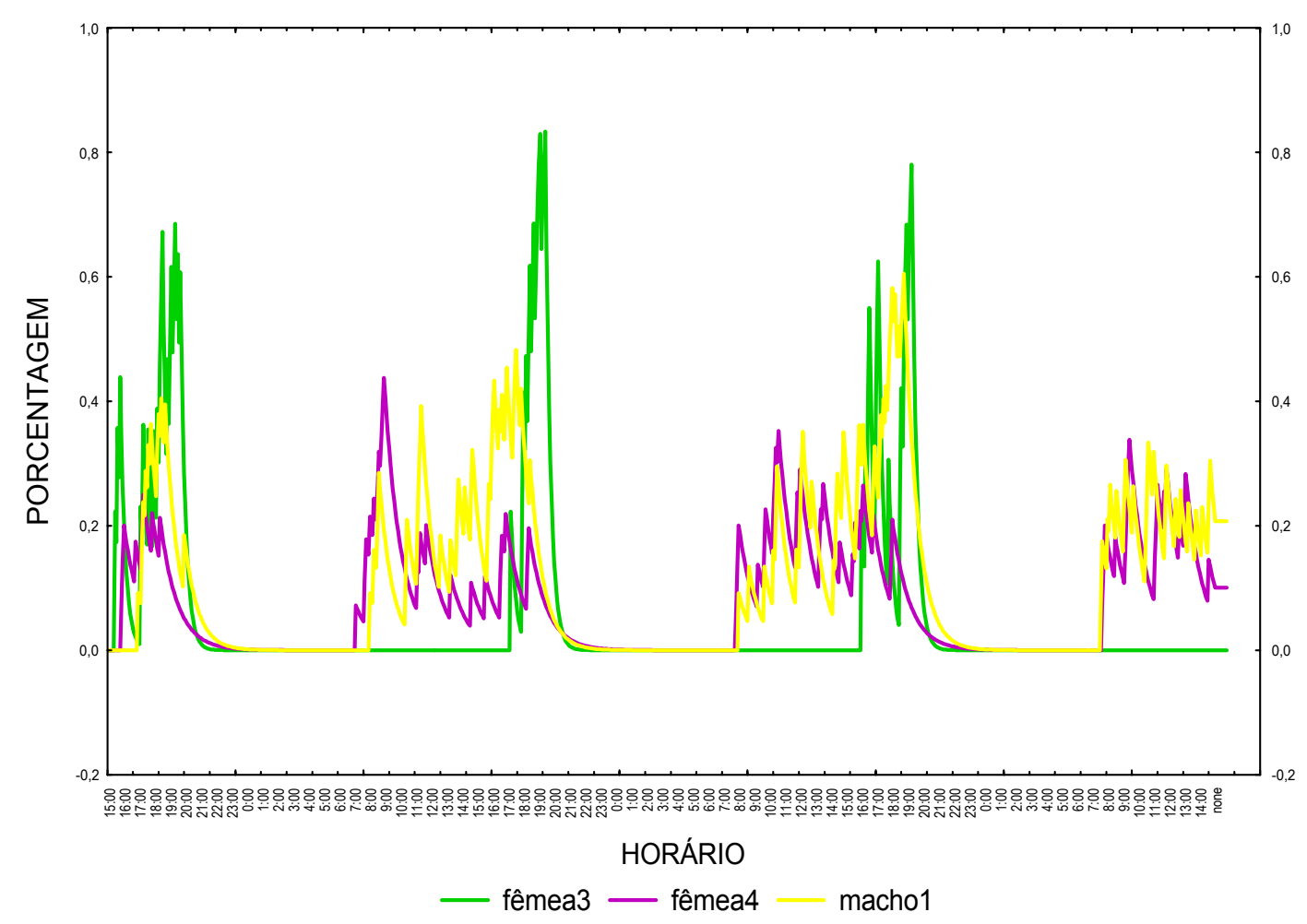

FIGURA 11 - Porcentagem da freqüência da categoria comer (CO) dos animais do box B.

As Figuras 12 e 13 representam a imobilidade (IM) dos boxes A e B, que são o resultado da soma dos comportamentos parado (PA) e sentado inativo (SP), ao desconsiderar-se a distribuição freqüencial desta categoria para a fêmea 3, e observando-se mais cuidadosamente apenas as fêmeas restantes, os demais animais, pode-se observar que houve um padrão formado para as fêmeas nesta categoria comportamental, o mesmo ocorrendo com os machos, porém de maneira oposta e com picos de surtos freqüenciais maiores que as fêmeas. 


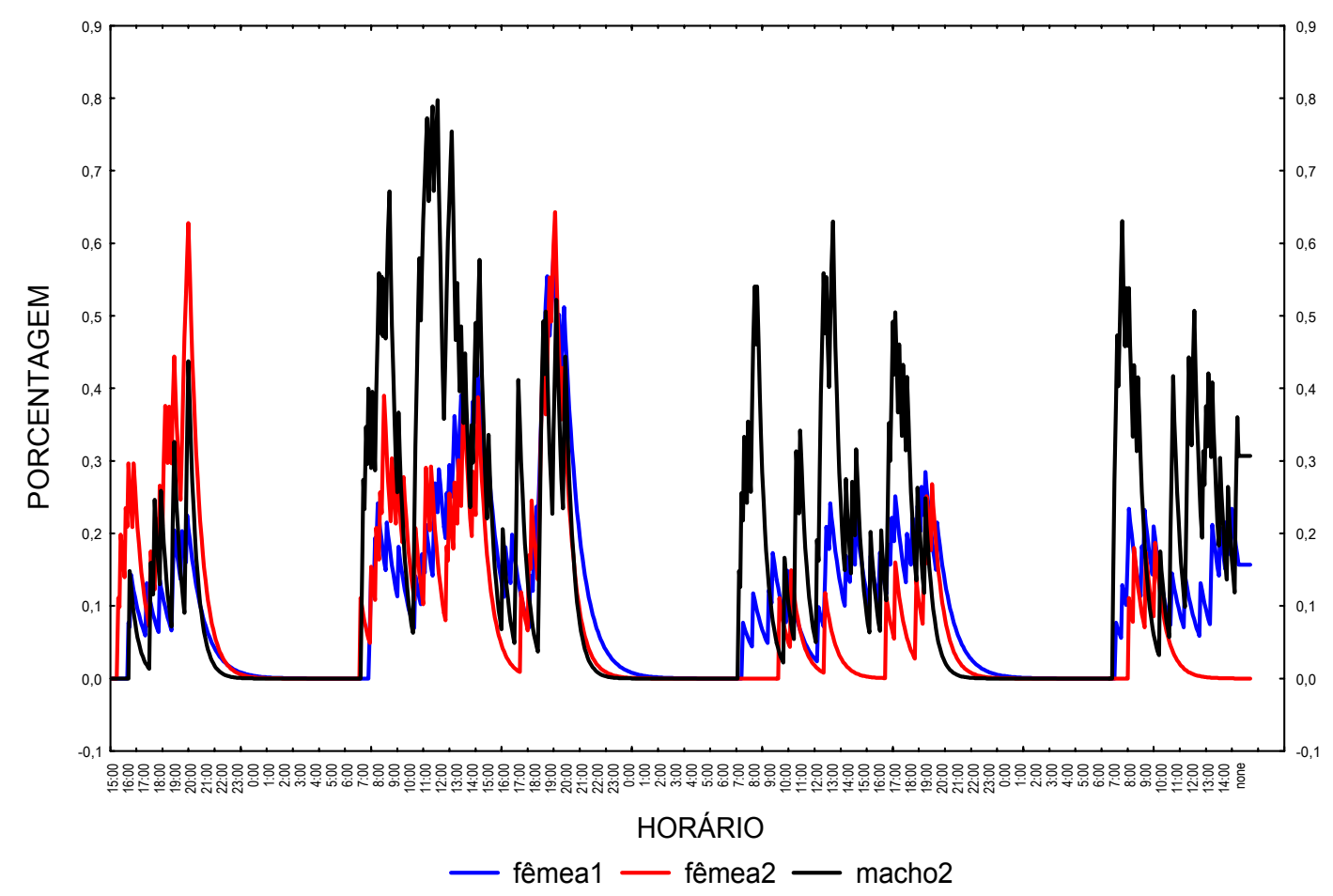

FIGURA 12 - Porcentagem da freqüência da categoria imobilidade (IM) dos animais do box A.

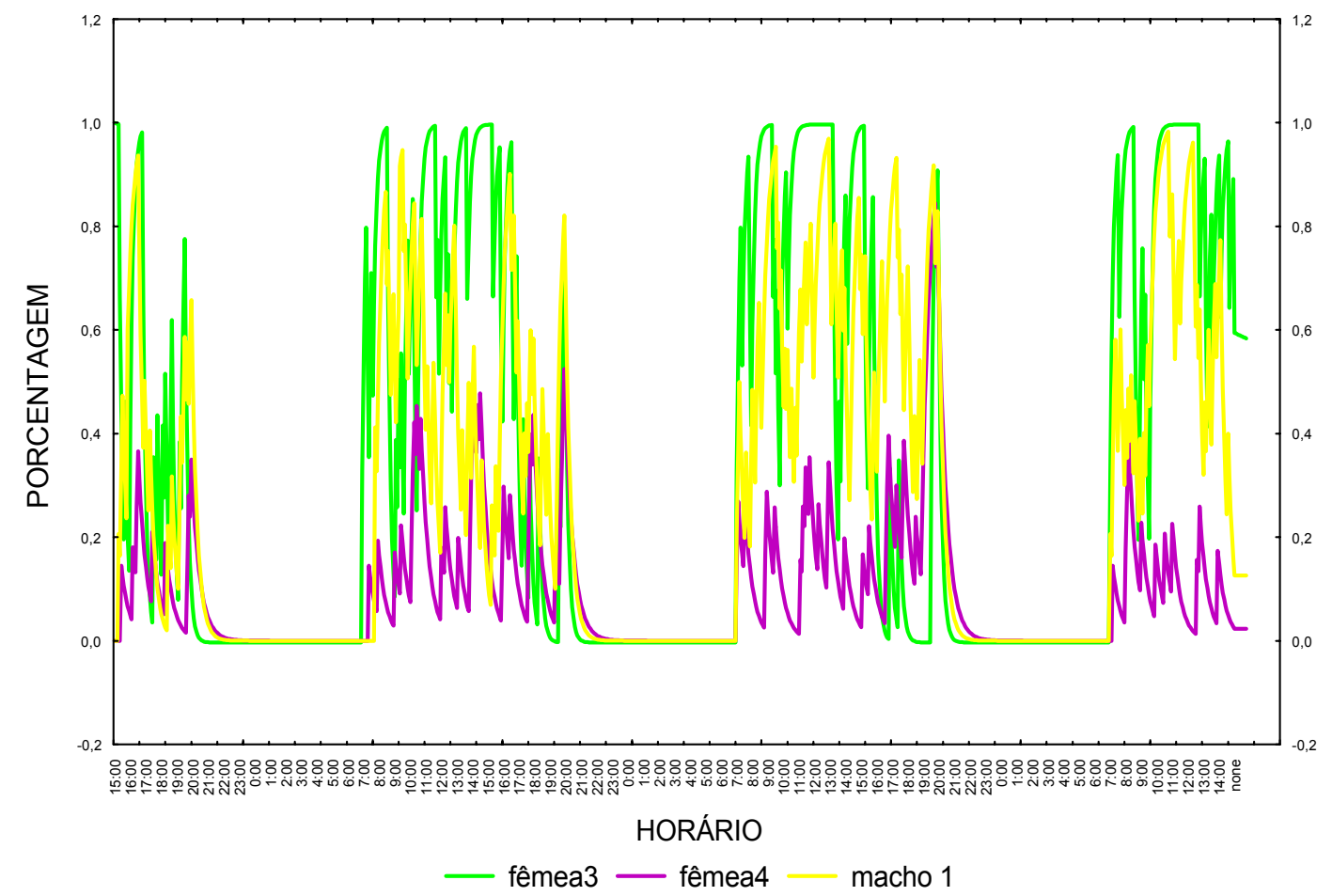

FIGURA 13 - Porcentagem da freqüência da categoria imobilidade (IM) dos animais do box B. 


\subsection{Freqüência Horária das Principais Categorias Comportamentais}

Entre as categorias comportamentais observadas, deslocamento (DE), parado (PA), ciscar (CS), arrumar (AR), sentado imóvel (SP), e comer (CO), foram as que ocorreram com maiores freqüências. As Figuras de 14 a 19, representam a freqüência, por hora, com que estas categorias, foram distribuídas ao longo do dia (8:00 às 19:00). O terceiro dia de filmagem foi escolhido como representativo para a confecção das Figuras. 


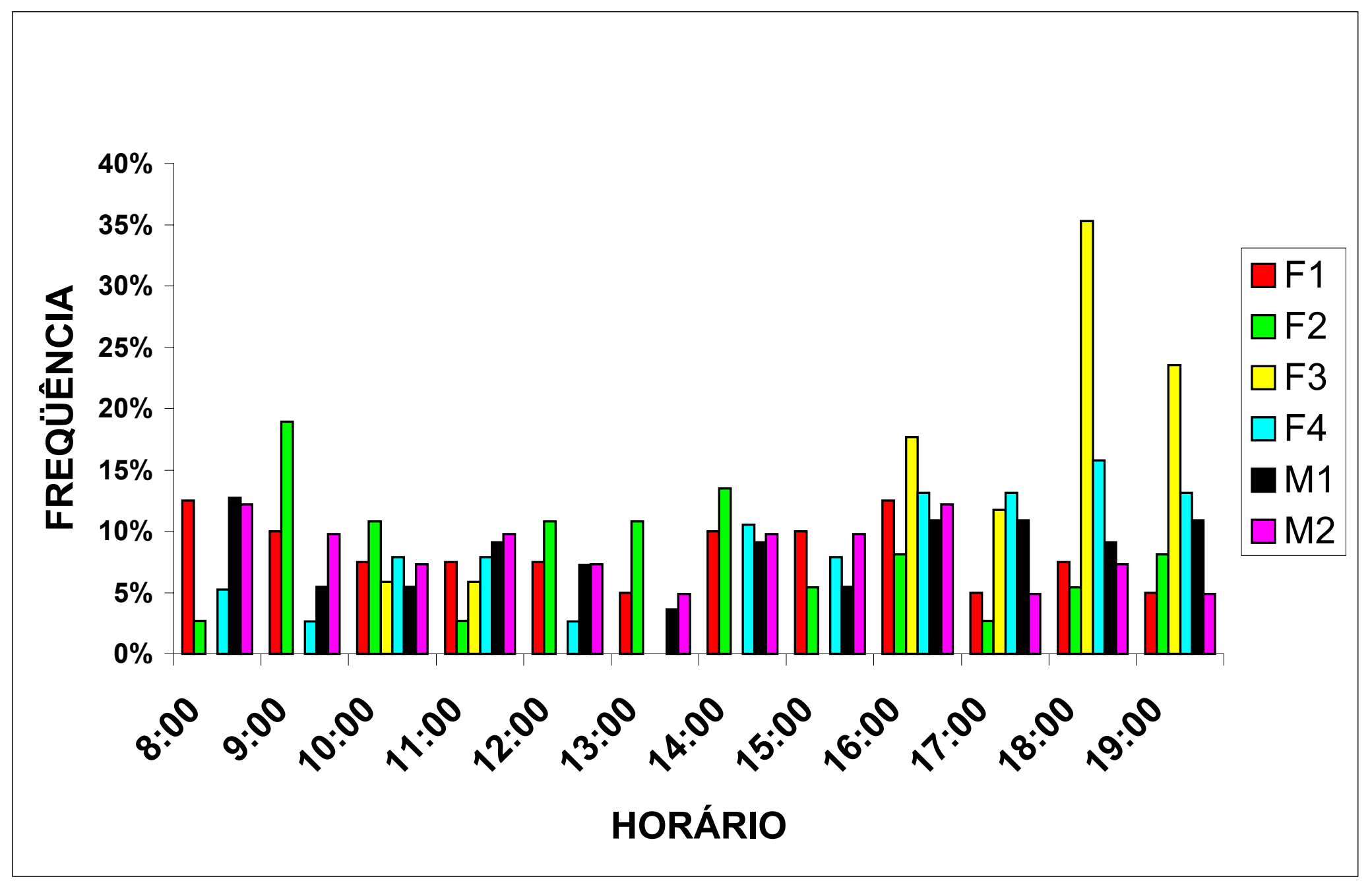

FIGURA 14 - Porcentagem de freqüência média para a categoria deslocamento (DE) no terceiro dia de observações. 


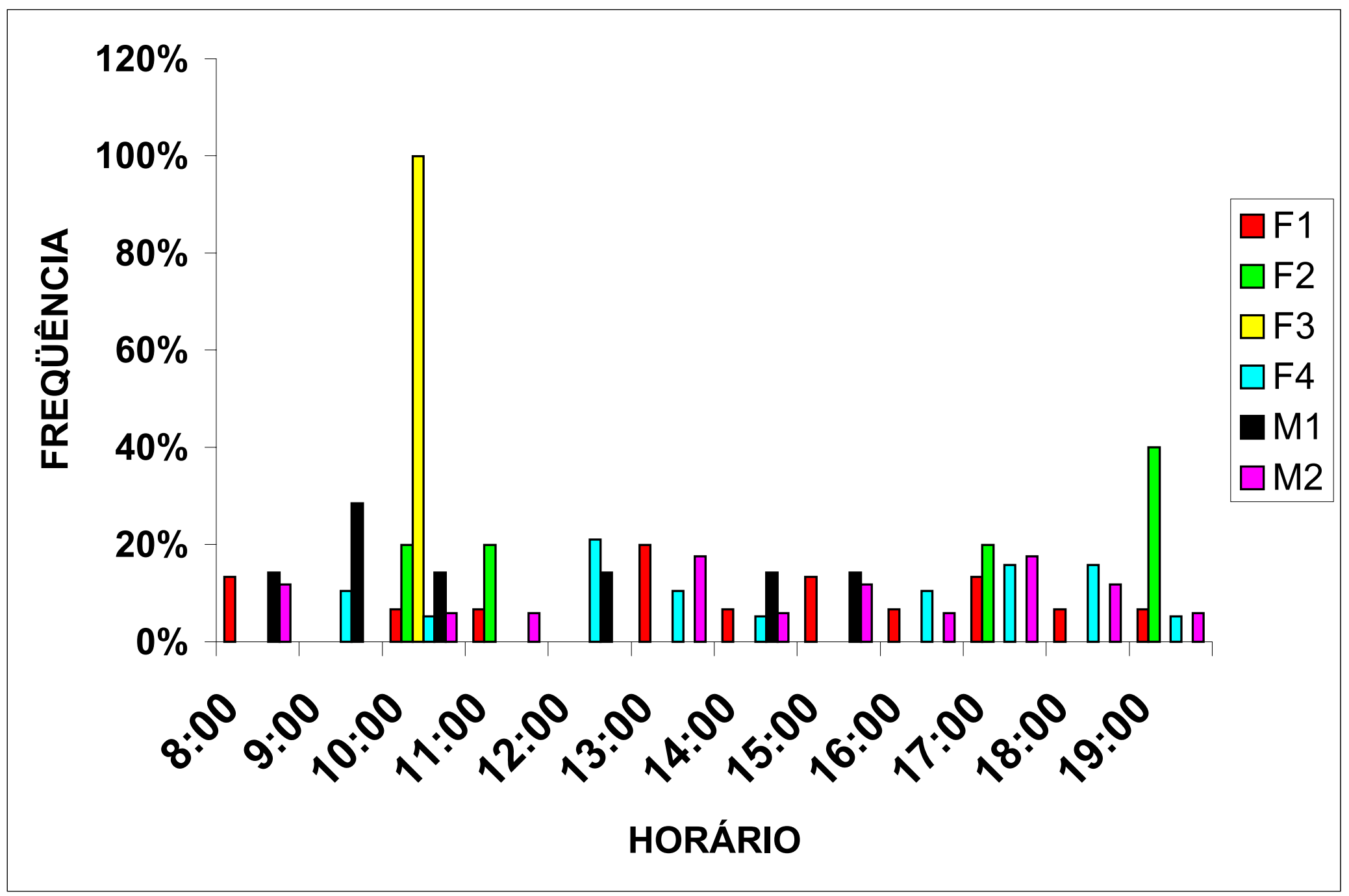

FIGURA 15 - Porcentagem de freqüência média para a categoria parado (PA) no terceiro dia de observações. 


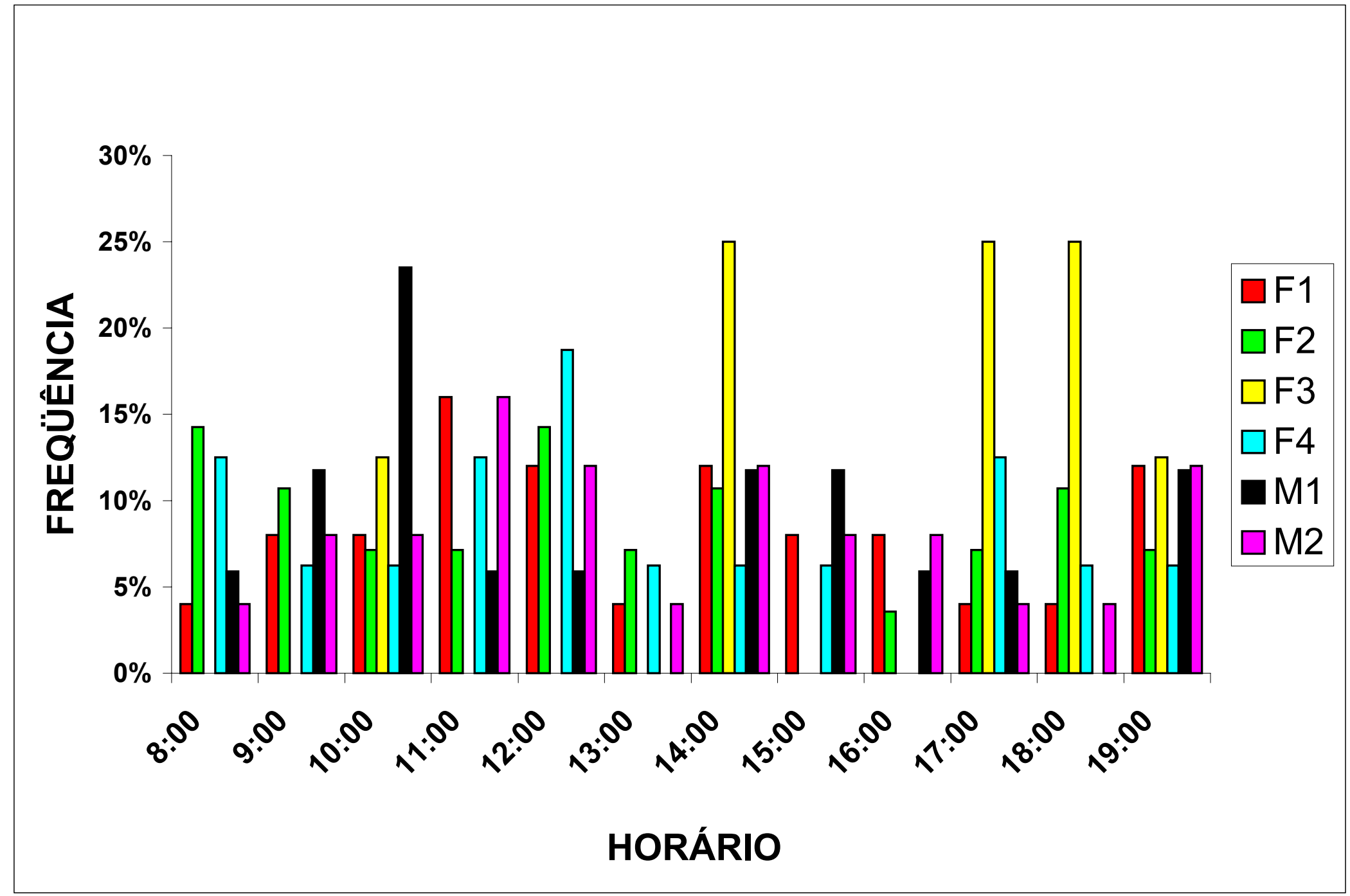

FIGURA 16 - Porcentagem de freqüência média para a categoria ciscar (CS) no terceiro dia de observações. 


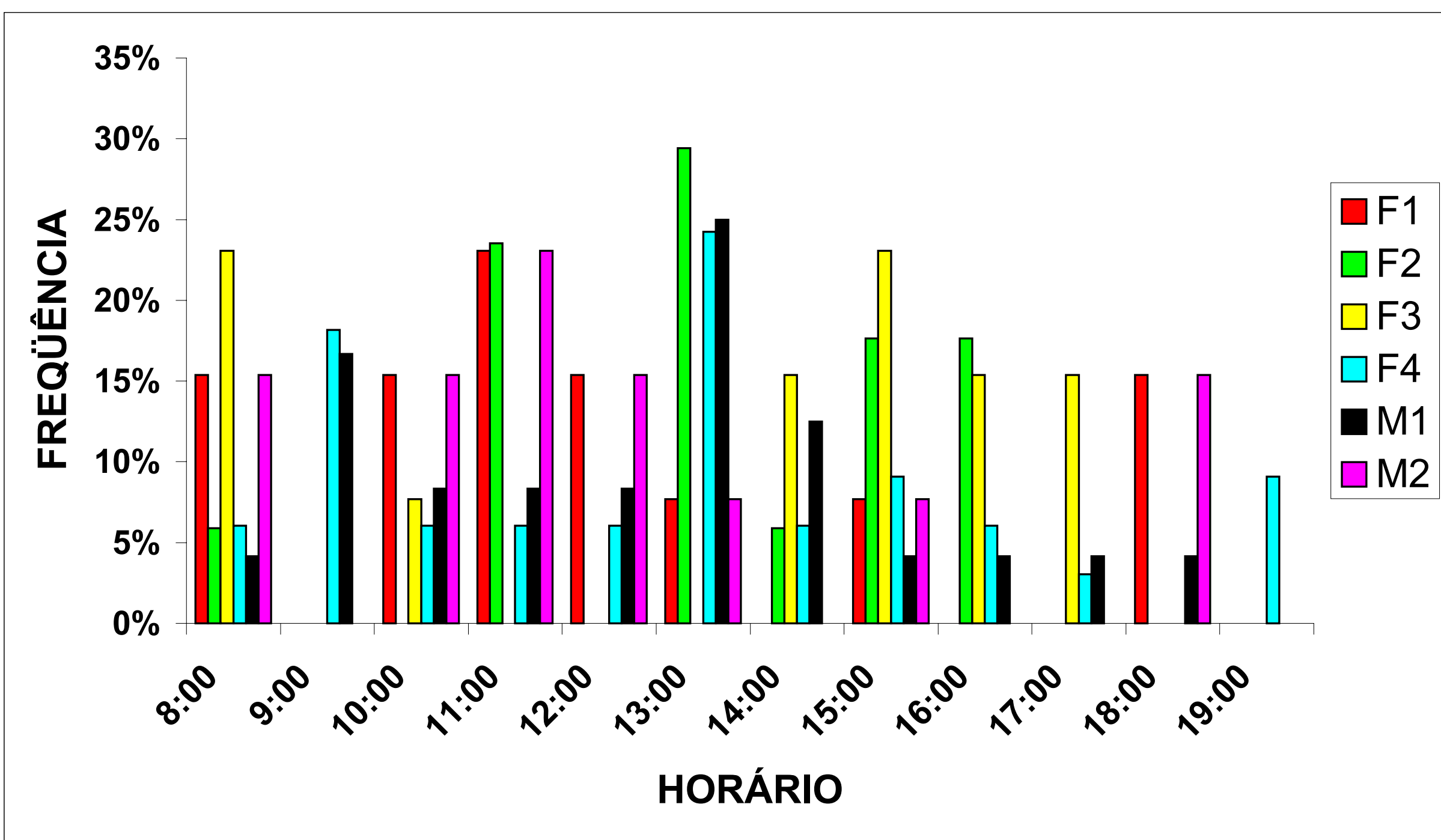




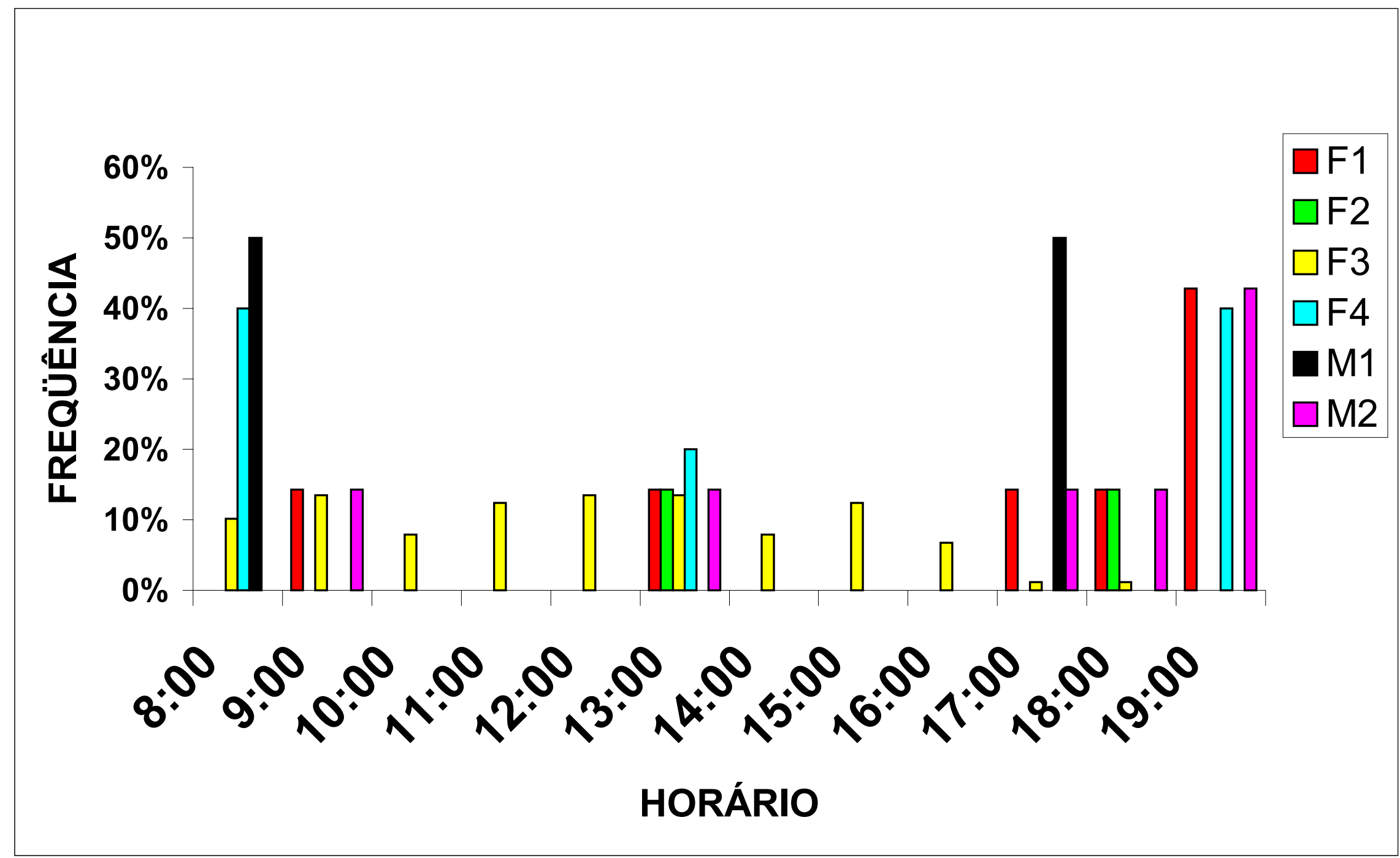

FIGURA 18 - Porcentagem de freqüência média para a categoria sentado inativo (SP) no terceiro dia de observações. 


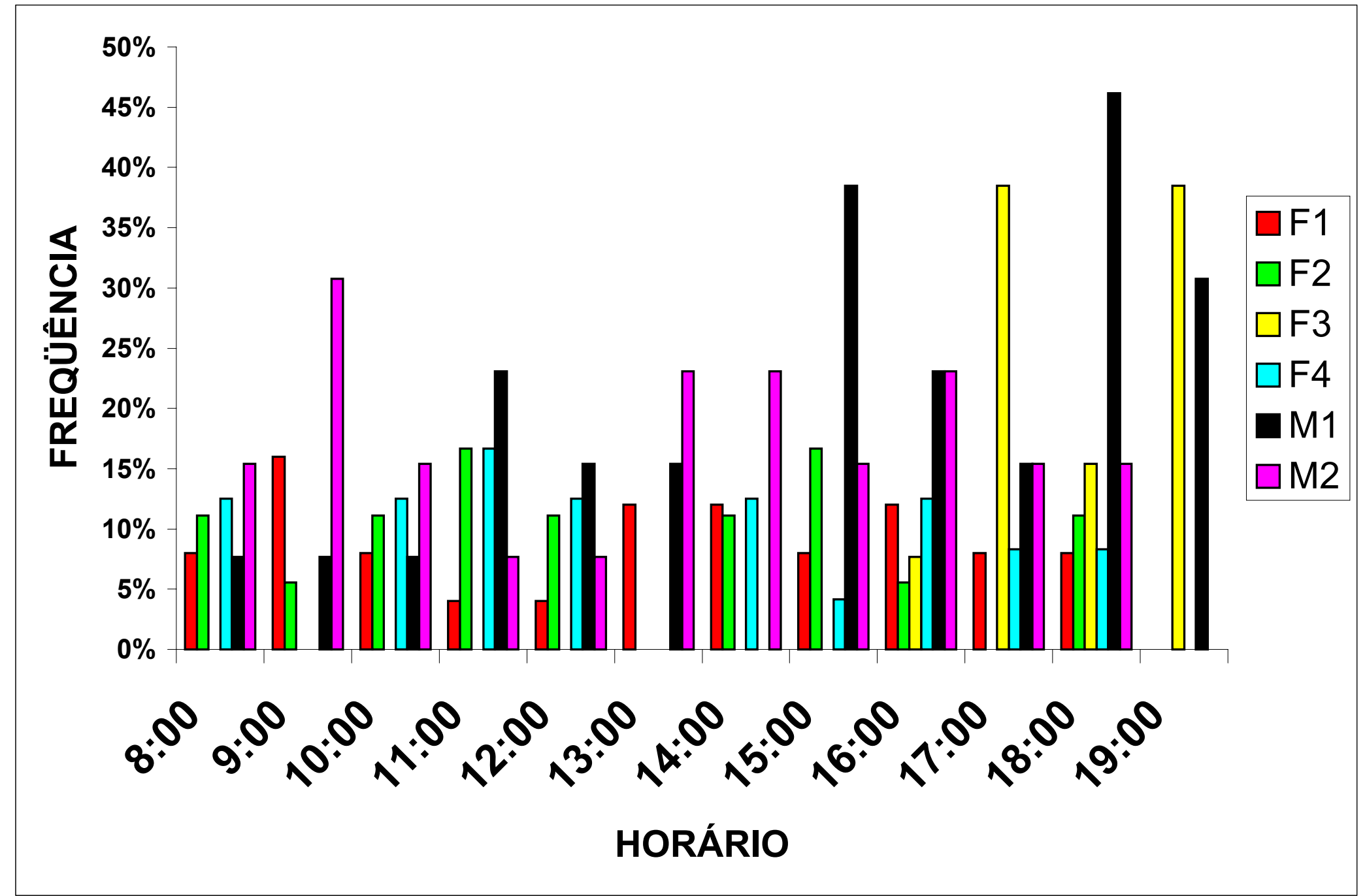

FIGURA 19 - Porcentagem de freqüência média para a categoria comer (CO) no terceiro dia de observações. 
Para a categoria deslocamento (DE), Figura 14, verificou-se que a fêmea 3 apresentou dois pequenos surtos de deslocamento no período da manhã, entre as 10 e 11 horas, depois deste intervalo voltou a se deslocar somente a partir das 16 horas, contrariamente à distribuição dos outros animais, que distribuíram mais uniformemente seu deslocamento ao longo do dia. A fêmea 4, que habitava o mesmo box da fêmea 3, tendeu a apresentar uma distribuição semelhante a esta; apresentando surtos freqüenciais menores no início da manhã, deslocando-se menos ao redor do meio dia e aumentando a freqüência do deslocamento no período da tarde. Esta tendência não foi vista no macho 1 que habitava o mesmo box (B) que estas fêmeas. O macho 1 mostrou uma distribuição freqüencial semelhante ao macho 2. As atividades das fêmeas 1 e 2 foram semelhantes entre si apresentando uma freqüência alta de deslocamento pela manhã, entre 8:00 e 9:00 horas.

A categoria parado (PA), Figura 15, mostra que a fêmea 3 ficou provavelmente uma hora no comportamento parado em pé, às 10:00 horas, não apresentando este comportamento durante as demais horas do dia. $A$ fêmea 2 foi outro animal que apresentou uma baixa freqüência de parado (PA) ao longo do dia, apesar de um pico às 19:00 horas, fato não observado nos demais animais.

Para a categoria ciscar (CS), Figura 16, chamou a atenção a discrepância da fêmea 3 , que demonstrou altas freqüências em horários determinados, em detrimento de uma distribuição mais uniforme. O macho 1 apresentou um pico de atividade para o ciscar às 10:00 horas, estando ausente em alguns horários (13:00 e 18:00 horas). Os demais animais possuíam uma distribuição mais uniforme durante o transcorrer do dia.

A arrumação (AR), Figura 17, mostrou uma falta de padronização para todos os animais ao longo do dia. Existiram horários distintos sem esta atividade, para cada uma das aves; com uma igual variação da freqüência a cada hora. 
A Figura 18, que diz respeito à categoria sentado imóvel, mostrou uma predominância do box B em mostrar esta categoria com maior freqüência, principalmente no início e no final das observações do dia. A fêmea 3, efetivamente passou a maior parte do tempo nesta postura. Quanto aos animais do box $A$, viu-se a fêmea 1 e o macho 2 nesta postura com maior freqüência no final do dia.

Para a categoria comer (CO), Figura 19, notou-se ao final do dia que a fêmea 3 e o macho 1 (do mesmo box) mostraram altas freqüências desta atividade. Quanto à sua distribuição, a fêmea 3 apareceu para se alimentar apenas no período da tarde, enquanto que todos os outros animais desenvolveram esta atividade ao longo do dia.

\subsection{Freqüências de Surtos Absolutos de Comportamento}

Com a finalidade de aprimorar os resultados coletados em relação à freqüência e surtos de ocorrência das categorias comportamentais, observouse 20 minutos, divididos no período da manhã, início e final da tarde (10:00/10:05, 13:00/13:10 e 16:00/16:05), cada animal continuamente em cada um dos três dias. A fêmea 3 não teve sua freqüência de surtos comportamentais registrados, devido ao baixo número de surtos apresentados.

A Tabela 4 apresenta o resultado da análise do Qui-Quadrado em relação aos animais observados. 
TABELA 4 - Freqüência dos atos comportamentais para os animais observados; agrupados em média entre fêmeas, entre machos e entre si

\begin{tabular}{|c|c|c|c|c|c|c|c|c|c|c|c|c|c|c|c|}
\hline Categoria & $\begin{array}{c}\text { fêmea } \\
1 \\
\end{array}$ & $\begin{array}{c}\text { fêmea } \\
2 \\
\end{array}$ & $\begin{array}{c}\text { fêmea } \\
4\end{array}$ & $\begin{array}{c}X^{2} \\
\text { (f1 e f2) }\end{array}$ & $\begin{array}{c}X^{2} \\
\text { (f1 e f4) }\end{array}$ & $\begin{array}{c}X^{2} \\
\text { (f2 e f4) }\end{array}$ & $\begin{array}{c}\text { macho } \\
1 \\
\end{array}$ & $\begin{array}{c}\text { macho } \\
2 \\
\end{array}$ & $\begin{array}{c}\mathrm{X}^{2} \\
(\mathrm{~m} 1 \text { e } \mathrm{m} 2)\end{array}$ & $\begin{array}{c}X^{2} \\
\text { (f1 e m1) }\end{array}$ & $\begin{array}{c}X^{2} \\
\text { (f1 e m2) }\end{array}$ & $\begin{array}{c}X^{2} \\
\text { (f2 e m1) }\end{array}$ & $\begin{array}{c}X^{2} \\
\text { (f2 e } m 2\end{array}$ & $\begin{array}{c}X^{2} \\
\text { (f4 e m1) }\end{array}$ & $\begin{array}{c}X^{2} \\
\text { (f4 e m2) }\end{array}$ \\
\hline $\mathrm{DE}$ & 114 & 119 & 39 & & $\mathrm{~A}$ & $\mathrm{~A}$ & 53 & 70 & & $\mathrm{~A}$ & $\mathrm{~A}$ & $\mathrm{~A}$ & $\mathrm{~A}$ & & $\mathrm{~A}$ \\
\hline AR & 11 & 7 & 11 & & & & 15 & 17 & & & & & & & \\
\hline CS & 0 & 0 & 0 & & & & 0 & 0 & & & & & & & \\
\hline AM & 2 & 6 & 1 & & & & 0 & 1 & & & & $B$ & & & \\
\hline $\mathrm{CO}$ & 22 & 34 & 7 & & $A$ & $A$ & 9 & 22 & & & & $\mathrm{~A}$ & & & A \\
\hline $\mathrm{SP}$ & 0 & 0 & 7 & & $\mathrm{~A}$ & $A$ & 2 & 9 & & & $\mathrm{~A}$ & & $A$ & & \\
\hline SA & 1 & 0 & 6 & & & $B$ & 1 & 9 & & & $B$ & & $A$ & & \\
\hline $\mathrm{BE}$ & 3 & 4 & 0 & & & & 0 & 1 & & & & & & & \\
\hline CÇ & 0 & 1 & 2 & & & & 1 & 0 & & & & & & & \\
\hline ER & 1 & 3 & 0 & & & & 0 & 1 & & & & & & & \\
\hline ES & 0 & 0 & 0 & & & & 0 & 0 & & & & & & & \\
\hline $\mathrm{BP}$ & 0 & 0 & 1 & & & & 2 & 2 & & & & & & & \\
\hline PA & 48 & 31 & 21 & & $A$ & & 16 & 24 & & $\mathrm{~A}$ & $\mathrm{~A}$ & & & & \\
\hline
\end{tabular}

f1...f4 - fêmea $1,2,3$ e 4.

m1..m2 - macho 1 e 2.

A - indica que o valor de $X^{2}$ é significativo a 0,01

$B$ - indica que o valor de $X^{2}$ é significativo a 0,02 . 
TABELA 5 - Freqüência dos atos comportamentais para os animais observados; agrupados em média de fêmeas e machos e como média para cada um dos boxes.

\begin{tabular}{c|c|c|c|c|c|c}
\hline Categoria & $\begin{array}{c}\text { Total de } \\
\text { fêmeas }\end{array}$ & $\begin{array}{c}\text { Total de } \\
\text { machos }\end{array}$ & $\begin{array}{c}\mathrm{X}^{2} \\
(\text { Tm e Tf) }\end{array}$ & $\begin{array}{c}\text { Total } \\
\text { Box A }\end{array}$ & $\begin{array}{c}\text { Total } \\
\text { Box B }\end{array}$ & $\begin{array}{c}\mathrm{X}^{2} \\
(\mathrm{BA} \text { e BB })\end{array}$ \\
\hline $\mathrm{De}$ & 90,7 & 61,5 & & 101 & 46 & $\mathrm{~A}$ \\
\hline $\mathrm{Ar}$ & 9,7 & 16 & & 11,7 & 13 & \\
\hline $\mathrm{Cs}$ & 0 & 0 & & 0 & 0 & \\
\hline $\mathrm{Am}$ & 3 & 0,5 & & 3 & 0,5 & \\
\hline $\mathrm{Co}$ & 21 & 15,5 & & 26 & 8 & $\mathrm{~A}$ \\
\hline $\mathrm{Sp}$ & 2,3 & 5,5 & & 3 & 4,5 & \\
\hline $\mathrm{Sa}$ & 2,3 & 5 & & 3,3 & 3,5 & \\
\hline $\mathrm{Be}$ & 2,3 & 0,5 & & 2,7 & 0 & \\
\hline $\mathrm{Cc}$ & 1,0 & 0,5 & & 0,3 & 1,5 & \\
\hline $\mathrm{Er}$ & 1,3 & 0,5 & & 1,7 & 0 & \\
\hline $\mathrm{es} 1$ & 0 & 0 & & 0 & 0 & \\
\hline $\mathrm{Bp}$ & 0,3 & 2 & & 0,7 & 1,5 & \\
\hline $\mathrm{Pa}$ & 33,3 & 20 & & 34,3 & 18,5 & \\
\hline
\end{tabular}

A - indica que o valor de $X^{2}$ é significativo a 0,01 .

Notou-se que nas Tabelas 4 e 5 para os animais individualmente, as fêmeas 1 e 2 se mostraram semelhantes para todas as categorias $\left(X^{2}\right.$ $p<0,01)$. A fêmea 4 diferiu das outras fêmeas nas categorias deslocamento $(\mathrm{DE})$, Comer (CO) e sentado inativo (SP). Os machos não diferiram entre si. Para comparar-se mais diretamente os machos com as fêmeas, calculou-se a média das freqüências de ocorrência para cada uma das categorias para as fêmeas, excetuando-se a fêmea 3 e para os machos, desta forma não encontrou-se diferenças significativas entre os sexos. Por outro lado, comparando-se individualmente as fêmeas com os machos notou-se que apenas a fêmea 4 teve todas as suas freqüências de surtos iguais ao macho 1 , que habitava o mesmo box. As diferenças nas freqüências dos surtos foram mais comuns nas categorias: deslocamento (DE), comer (CO), sentado inativo ou ativo (SP e SA) e parado (PA). A média das freqüências dos surtos para cada box, excluindo também a fêmea 3 , diferiu apenas entre 
as categorias deslocamento (DE) e comer (CO). Os animais do box A apresentaram mais surtos de deslocamento (DE) e comer (CO) que os animais do box $B$.

\subsection{Análise dos ritmos diários de atividade de alguns comportamentos}

A observação das Figuras mostradas revelou uma tendência a padrões rítmicos para as categorias estudadas; os animais apresentaram ciclos para as categorias que se iniciavam ao início do dia, quando já havia luz suficiente para as filmagens que iam das 6:55 $\mathrm{h}$ até às 19:50 $\mathrm{h}$. 0 alimento dos comedouros era colocado antes do início da filmagem.

A análise espectral analisou com maior precisão os padrões de ritmicidade visualizados nas Figuras apresentadas. A Figura 20 mostra o periodograma obtido para a categoria comer $(\mathrm{CO})$ para o macho 1. Em todas as categorias detectou-se um ritmo de 24 horas. A detecção de outros ritmos com periodicidades distintas para algumas categorias adquiriram maior relevância.

A Figura 20 foi escolhida aleatóriamente para observar-se a forma gráfica de saída da análise efetuada. O ponto mais alto indica a periodicidade principal identificada e corresponde ao ciclo circadiano de 24 horas. Entretanto, notou-se que existiu um outro ponto em evidência, correspondendo a um ciclo secundário de 8 horas. Ao observar-se a Figura 20 foi possivel identificar esta periodicidade, em que a cada 8 horas tem-se uma repetição do padrão freqüencial para a categoria comer (CO). 


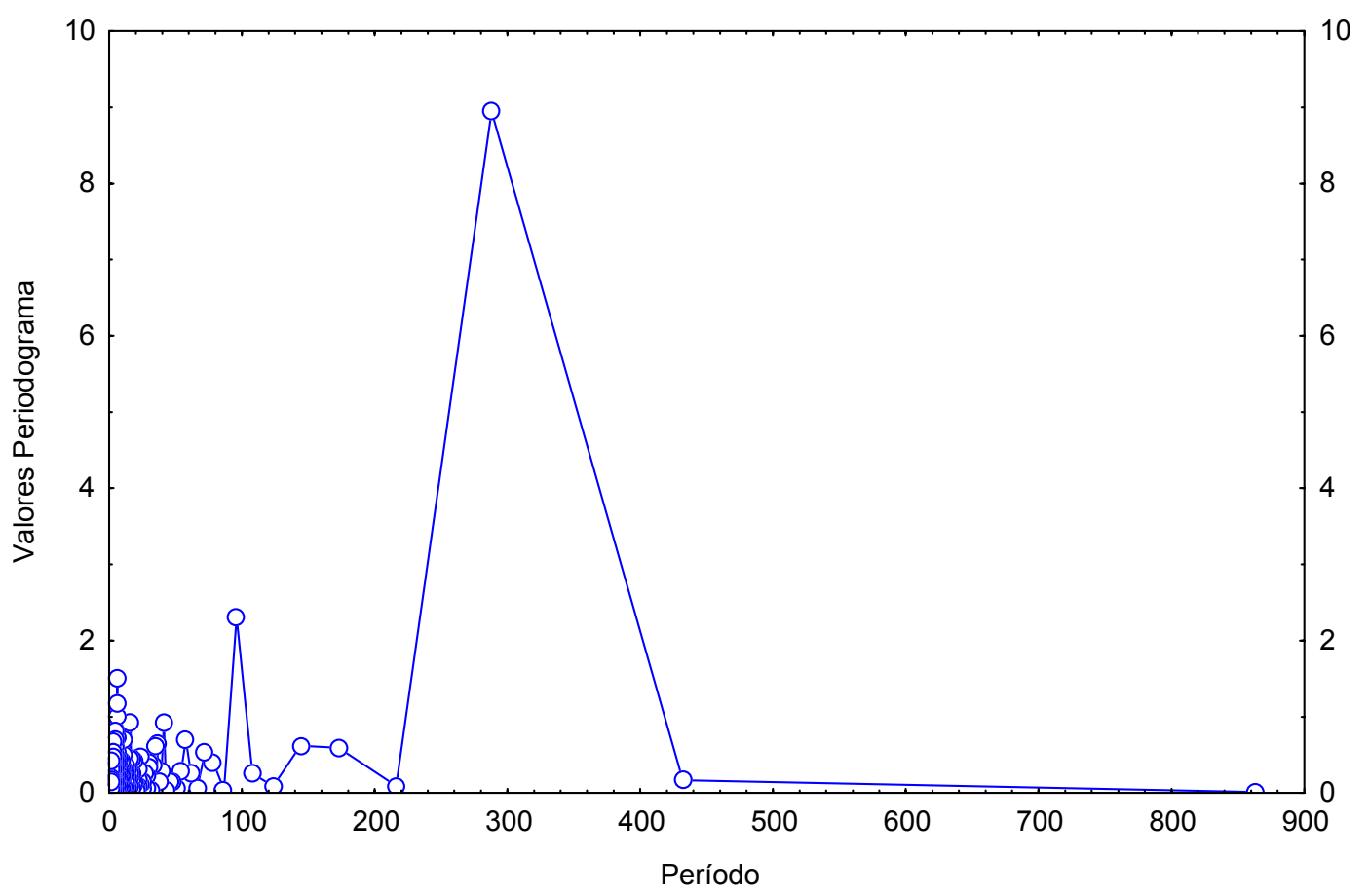

FIGURA 20 - Análise espectral do macho 1 para categoria comer (CO).

A presença do ritmo circadiano (período maior que 20 e menor que 28 horas, geralmente próximo a 24 horas) em padrões de atividades diárias na maioria dos animais foi um resultado esperado, por expressar a regularidade circadiana das atividades dos animais para deslocamento (DE), comer (CO), arrumação (AR), ciscar (CS) e imobilidade (IM). Como para todos os animais e comportamentos a hora do início e término da maioria das atividades foram coincidentes, é natural o surgimento freqüente de um ritmo de 12:00 h., harmônico de 24:00 h.

Para todas as categorias encontrou-se a existência de um ritmo ultradiano (período menor que 20 horas), à exceção de alguns animais. Para a categoria comer (CO), o ritmo ultradiano encontrado é de 8 horas para todos os animais à exceção da fêmea 2. Este animal apresentou uma periodicidade de 6 horas.

Para a categoria deslocamento (DE), o ritmo ultradiano em todos os animais se encontrou ao redor de 8 horas. Já para a imobilidade (IM), notouse que o macho 1 e as fêmeas 2 e 4 apresentaram um ritmo ultradiano de 8 
horas, enquanto o macho 2 e a fêmea 1 mostraram um ritmo de 6 horas. Diferenciando-se das outras a fêmea 3, que apresentou ritmo de 4 horas para esta categoria.

A arrumação (AR) tendeu a exibir um ritmo ultradiano de 8 horas para todos os animais, enquanto que o ciscar (CS) mostrou um ritmo ultradiano de 8 horas para as fêmeas 1 e 2 e para o macho 2, que habitavam o box $A$, enquanto que para o Box B não identificou-se um ritmo ultradiano.

\subsection{Organização do Comportamento da Perdiz no Cativeiro.}

Utilizando-se os dados obtidos pela observação contínua em diversos horários do dia, construiu-se uma matriz de transição para as fêmeas e uma para os machos, tentando avaliar as diferenças na organização estrutural do comportamento que poderiam estar ligadas à reprodução, notadamente ao acasalamento. A baixa freqüência com que estes comportamentos, e até mesmo os agonísticos, ocorreram, fizeram com que não fossem detectadas diferenças individuais quanto à organização estrutural, assim apresentandose a análise dos animais agrupados por sexo.

\subsubsection{Interpretação dos Diagramas em Forma de Árvores}

A interpretação dos diagramas em forma de árvores obtidos, segundo a metodologia descrita no Anexo A, pode ser feita seguindo-se o roteiro apresentado por CROMBERG (1995). Tomou-se a árvore orientada das fêmeas com parado (PA) como raiz na solução fonte como exemplo (Figura 21). Como a árvore está representando a solução fonte (as transições que aconteceram dado o ato como raiz), ela deve ser analisada de baixo para cima. As associações seqüenciais estão representadas pelas ligações verticais, cada uma delas ligando dois atos (do ato de baixo para o ato de cima). Os valores à esquerda do gráfico representam a probabilidade do caminho da raiz até outro ato (o valor 0,164 representa a probabilidade 
incondicional de PA). Para se chegar em comer (CO), o caminho mais provável é (PA-DE-CO); a probabilidade deste caminho é $\mathrm{P}(\mathrm{PA}-\mathrm{DE}-\mathrm{CO})=$ 0.027. Existem outros caminhos na matriz de transição que partindo de parado (PA), chegam em comer (CO), mas eles são menos prováveis que o enumerado pela árvore orientada.

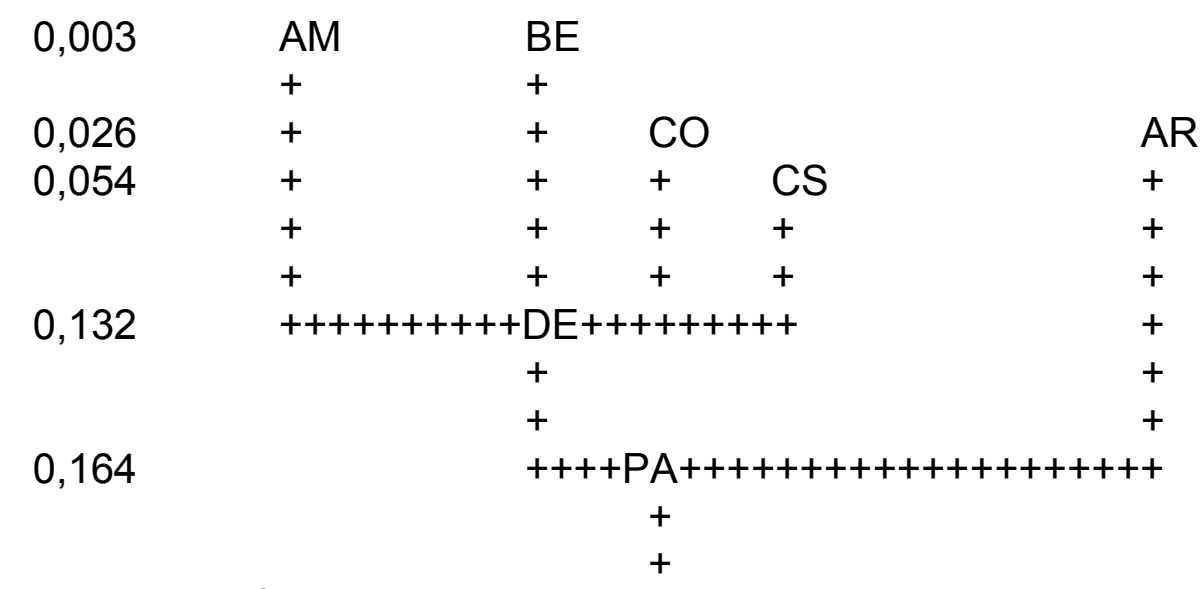

FIGURA 21 - Árvore orientada mais provável do ato parado (PA) como raiz, solução fonte, obtida a partir da matriz de transição das fêmeas (ver anexo II). Os valores da ordenada representam a probabilidade do caminho da raiz até um vértice (um outro ato). A chave de identificação dos atos (etograma) pode ser vista nas fls. 27 e 28. Como se trata de solução fonte o diagrama deve ser examinado de baixo para cima.

Com respeito à associação por equivalência , a árvore da Figura 21 refere-se à solução precedente. Nesta árvore, deslocamento (DE) e arrumação $(A R)$ são candidatos à associação por equivalência, pois tiveram em comum o ato precedente parado (PA). Para confirmar a associação por equivalência, esses atos não podem mostrar associação seqüencial entre si. No presente caso, os atos estavam associados seqüencialmente e portanto não apresentavam equivalência pelo ato precedente comum, parado (PA).

Em relação à associação seqüencial, SATO (1993) salienta que a rigor apenas duplas podem ser consideradas na análise, visto utilizar-se uma matriz de transição de $1^{a}$ ordem. As duplas identificadas pelas árvores orientadas, como por exemplo as duplas (PA-DE), (DE-CS) da Figura 21, ocorreram mais freqüentemente que o esperado pelo acaso. Um arranjo de ordem superior a um, como por exemplo o caminho (PA-DE-CS), pode ou não ocorrer na seqüência; e ainda, dado que a árvore orientada foi 
construída de caminhos elementares, os arranjos seqüenciais nos quais o ato foi repetido nunca foram recuperados pela árvore orientada. Um caminho ou um pedaço selecionado dele, foi composto por atos que foram mais fortemente relacionados um com outro do que com atos que foram mais afastados na árvore. Assim na Figura 21, parado (PA) está mais fortemente relacionado com deslocamento (DE) do que ciscar (CS).

Num diagrama de árvore orientada a relação entre dois atos pode ser do tipo predecessor ou sucessor. $O$ ato $A$ é o predecessor de $B$ se $A$ atinge $B$ e, B é dito o sucessor de A. Na Figura 21 , beber (BE) está relacionado com parado $(\mathrm{PA})$, porque $\mathrm{BE}$ é sucessor de $\mathrm{PA}$. O grau de relacionamento pode ser dado pelo número de passos de um ato a outro. Então, PA está mais relacionado com arrumação (AR), um passo, do que $B E$, dois passos. No diagrama de árvore orientada só pode-se ter certeza sobre os caminhos mais prováveis que se iniciam na fonte.

$\mathrm{Na}$ árvore orientada, alguns atos não estão relacionados pela relação predecessor/sucessor, mas podem ter um predecessor em comum: por exemplo, ciscar (CS) e beber (BE) têm deslocamento (DE) como predecessor comum; parado (PA), também é um predecessor comum, mas $\mathrm{DE}$, pode-se dizer, é mais "recente". O grau de relacionamento entre os dois atos citados pode ser medido pela soma do número de passos do predecessor comum até estes atos (dois no exemplo).

A árvore pode ser ainda usada como um instrumento de classificação. O diagrama de árvore orientada pode ser desconectado, removendo-se algumas flechas, resultando em sub-estruturas isoladas. Na Figura 21 a remoção da flecha que ligou parado (PA) a arrumação (AR), agrupou os atos $A R$ e CÇ (coçar), que constituem os atos ligados à limpeza corporal. A remoção da flecha entre $\mathrm{PA}$ e $\mathrm{DE}$, agrupa os atos que representam atividade. A separação pode ser feita com base em uma hipótese prévia e 
mostra as possibilidades de seu emprego como técnica classificatória, permitindo a confirmação da existência de grupos hipotéticos.

A Figura 22 apresenta a árvore orientada com a raiz parado (PA) no sumidouro para as fêmeas. Como representa uma solução de sumidouro, as árvores devem ser inspecionadas de cima para baixo. Vemos que alguns caminhos nesta árvore são inversos ao descrito na árvore com raiz na fonte PA, como por exemplo o caminho (CS, DE, PA). Se a direção e o valor das flechas não forem considerados, então esta árvore mostra em diversos pontos a mesma estrutura da árvore apresentada na Figura 22 , sugerindo a ocorrência de um grande número de transições simétricas no comportamento das perdizes. As únicas assimetrias são a não ocorrência de beber (BE) e o aparecimento de coçar (CÇ). As associações CS-DE, AMDE, CO-DE mantêm-se na árvore tendo a raiz como sumidouro, o que sugere repetições do tipo ABABAB... entre DE e CS; DE e AM e DE e CO.

0,004

CÇ

0,015

0,017

AR

0,027

0,048

0,127

0,164

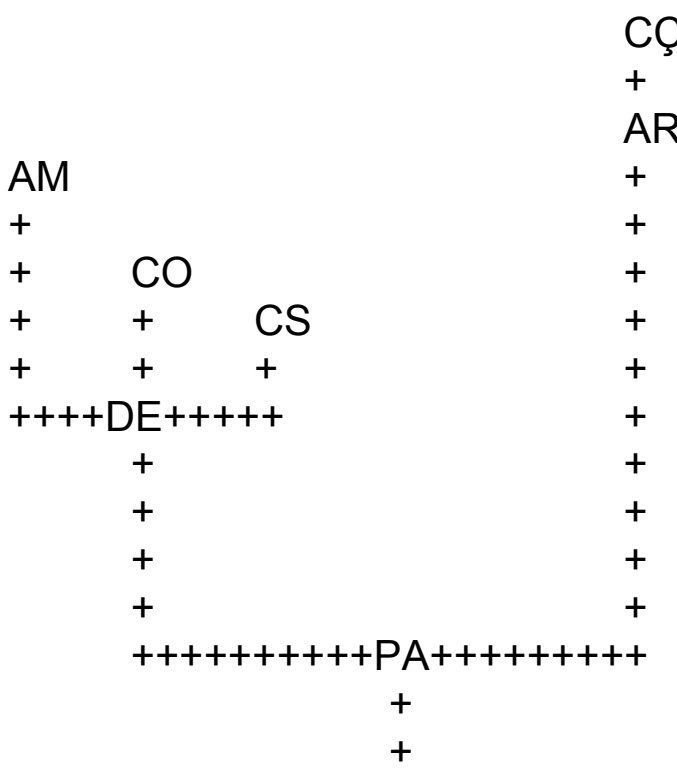

FIGURA 22 - Árvore orientada mais provável das fêmeas, raiz PA é sumidouro. Os valores das probabilidades condicionais (lado esquerdo) não estão em escala 


\subsection{Organização Estrutural}

Basicamente os resultados podem ser observados a partir de algumas árvores representativas (Figuras 23 a 28) entre todas as árvores geradas, além das duas já apresentadas.

As árvores com deslocamento com raiz para solução fonte para machos e fêmeas (Figuras 23 e 24), serve para exemplificar que no geral as árvores orientadas das fêmeas apresentaram-se mais estereotipadas do que as dos machos, no sentido de mais organizadas, fazendo com que um número maior de associações fosse identificado. O deslocamento serviu como uma categoria de entrada e saída para os mais diferentes atos.

Apenas para as fêmeas (Figura 23) o parado (PA) também funcionou como entrada ou saída para a arrumação (AR); para os machos PA funciona mais como entrada com $A R$, saindo mais freqüentemente pelo ato $D E$. $O$ coçar (CÇ) se associou nas fêmeas com a arrumação (AR), constituindo o que pode-se chamar de atos direcionados ao cuidado corporal, que forma um grupo de atos separado dos outros, não podendo ser acessado a partir do ato AR, após deslocamento ou parado. Apesar de poder-se dizer que uma vez executado o CÇ a maior probabilidade é que ocorra $A R$, após a ocorrência de AR, a fêmea têm maior probabilidade de ficar parada ou se deslocar, não estando estabelecido que comportamento antecede CÇ. Os machos apresentaram o que se pode chamar de uma maior plasticidade para a arrumação corporal, ao não ficar determinado nenhuma associação com CÇ.

Outra constatação foi a transição alternada do tipo $A B A B$ que ocorreu entre sentado ativo (SA) e sentado imóvel (SP), para machos e fêmeas (Figuras 27 e 28), entretanto não ficou definido qual comportamento serviu de entrada ou saída para estes surtos de alternância. 
As Figuras 25 e 26 representam a solução sumidouro para a raiz deslocamento (DE) e foram utilizadas para se montar a Figura 28 que resume as associações seqüenciais.

0,089

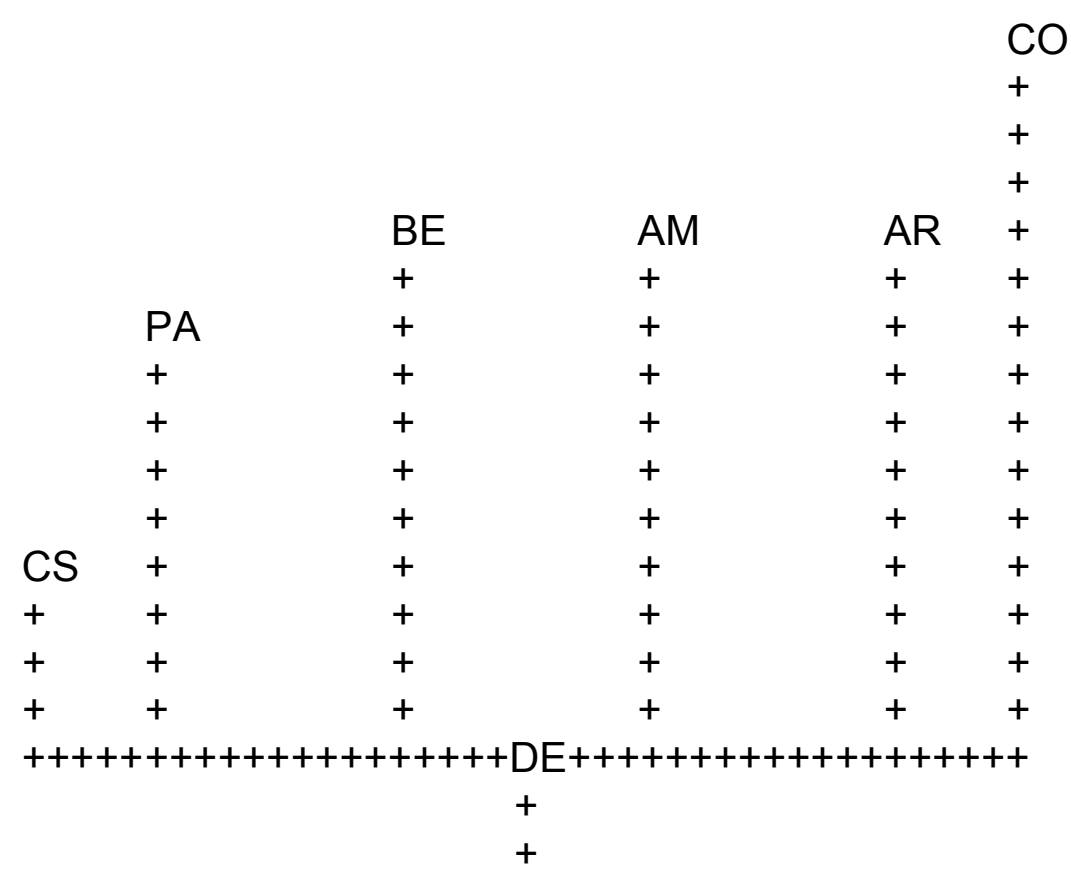

FIGURA 23 - Árvore tendo o deslocamento (DE) como raiz fonte para fêmeas, as probabilidades condicionais (lado esquerdo) não estão em escala.

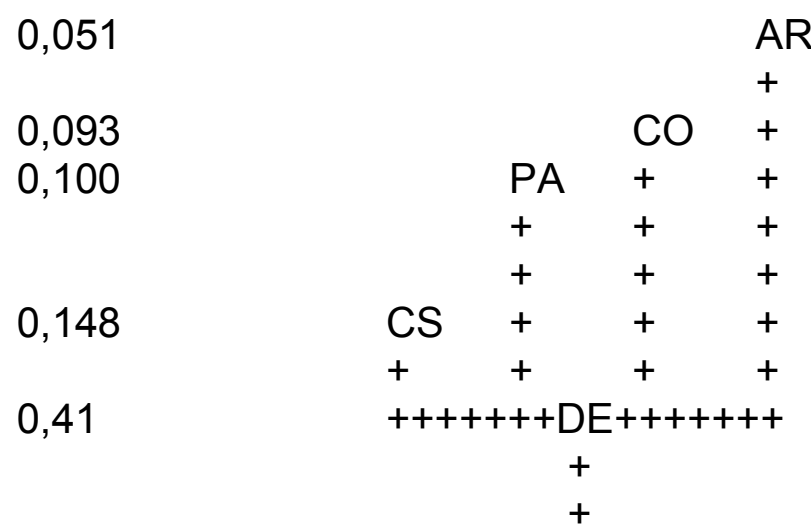

FIGURA 24 - Árvore tendo o deslocamento (DE) como raiz fonte para machos, as probabilidades condicionais (lado esquerdo) não estão em escala. 


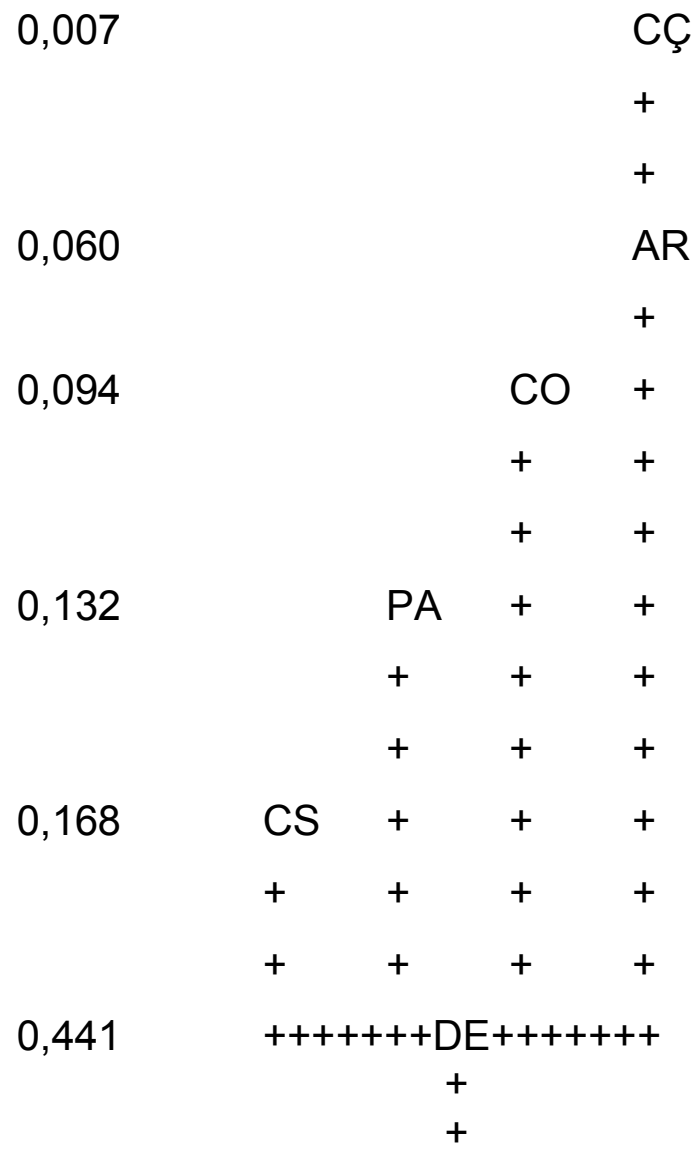

FIGURA 25 - Árvore tendo o deslocamento (DE) como sumidouro para fêmeas, as probabilidades condicionais (lado esquerdo) não estão em escala.

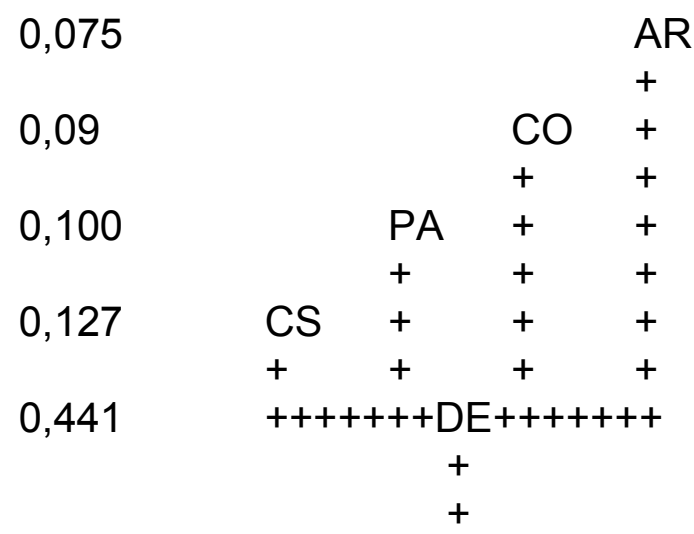

FIGURA 26 - Árvore tendo o deslocamento (DE) como sumidouro para machos, as probabilidades condicionais (lado esquerdo) não estão em escala 


$\begin{array}{rlll}0,031034 & \text { SA } & 0,010067 & \text { CO } \\ & + & & + \\ 0,034483 & + & & + \\ & \text { SP } & 0,011745 & \text { SP } \\ & + & & + \\ & + & & + \\ & \text { O } & & +\end{array}$

(A)

$\begin{aligned} 0,020689 & \text { SA } & 0,010067 & \text { SA } \\ & + & & + \\ 0,226891 & \text { SP } & & + \\ & + & 0,011745 & \text { SP } \\ & + & & + \\ & \text { O } & & + \\ & & & +\end{aligned}$

(B)

FIGURA 27 - Em (A) a raiz SP é fonte, em (B) é sumidouro para machos e fêmeas respectivamente. 


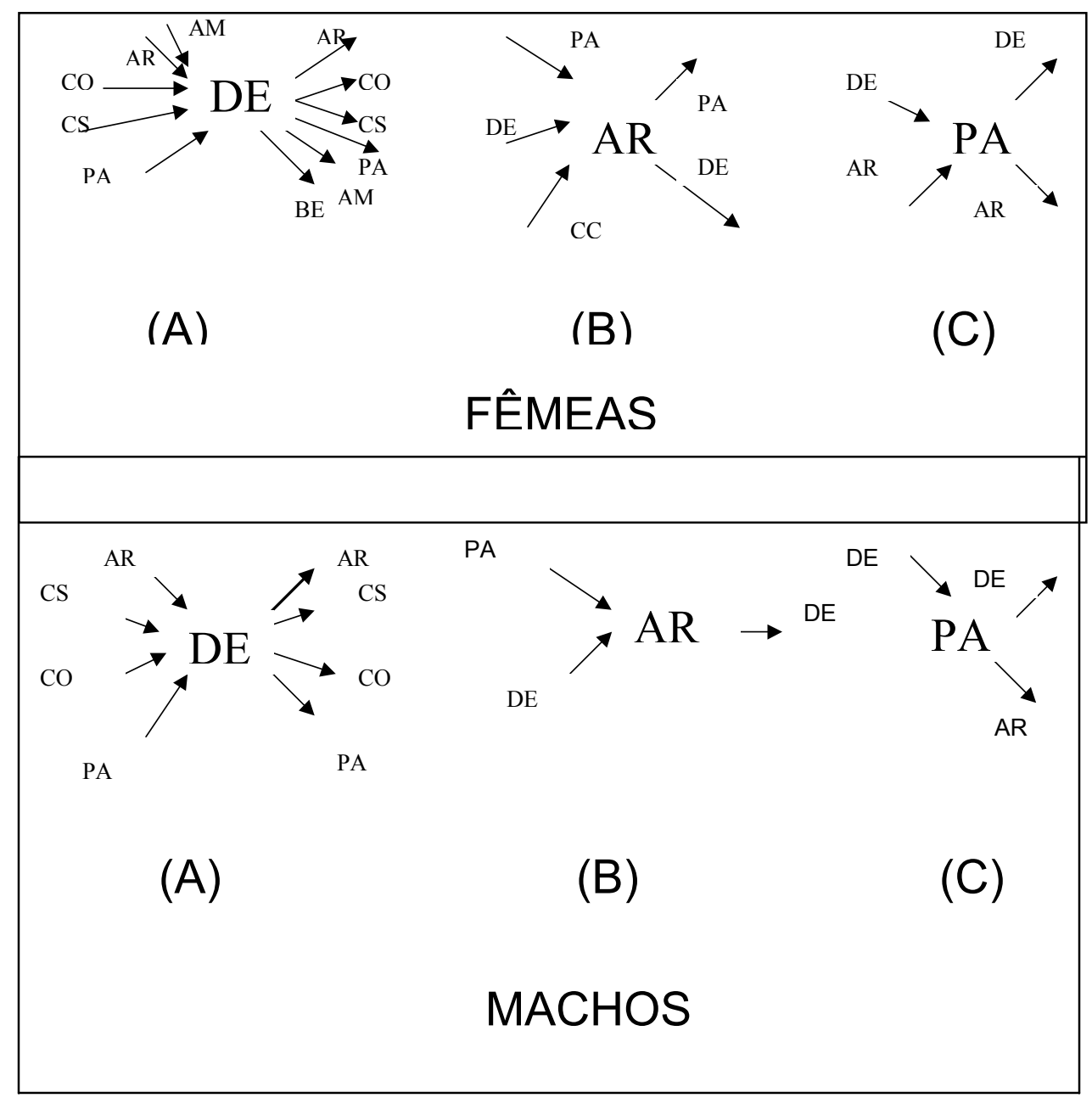

FIGURA 28 - Associações seqüenciais observadas. Em (A) DE é raiz , (B) AR é raiz e em (C) PA é raiz.

A partir da Figura 28 verificou-se que o deslocamento (DE) precedeu AR, CO, CS e PA e sucedeu estas mesmas categorias. AR antecedeu DE e sucedeu PA e DE, e PA antecedeu DE e AR e sucedeu DE. As diferenças observadas quanto ao sexo foram para as fêmeas: 1) AM precedeu $D E ; 2$ ) AM e BE sucederam DE; 3) CÇ precedeu AR; 4) AR precedeu PA. Porém a observação da matriz de transição para os machos (anexo B) indicou a existência das associações citadas para as fêmeas, à exceção de CÇ que foi zero. Assim os caminhos não representados para os machos foram devido à existência de outros com maior probabilidade de ocorrência. 
Quanto à equivalência precedente, que indica quando dois ou mais atos foram precedidos por um mesmo ato comportamental, verificou-se que, para os machos, os atos AR, CS, CO e PA foram candidatos à equivalência através do ato precedente $D E$ e para as fêmeas os atos AR, CS, CO, PA, $A M$ e $B E$ foram os candidatos ao mesmo ato $D E$. Uma verificação na matriz de transição (anexo B) confirma que as transições entre esses candidatos não foram estatisticamente significantes entre si, com exceção dos atos PA e AR tanto para os machos como para as fêmeas.

A equivalência subseqüente indica quando dois ou mais atos foram seguidos por um único ato. Para os machos, os atos AR,CS,CO, e PA foram candidatos a equivalência através do ato subseqüente $D E$ e para as fêmeas os atos AR, CS, CO, PA, e AM foram os candidatos ao mesmo ato DE. Uma verificação na matriz de transição só não confirmou PA e AR para as fêmeas.

A equivalência completa entre dois atos surge quando existe um antecessor e um sucessor comum. $\mathrm{CO}$ e CS são associados por equivalência completa através do ato precedente e subseqüente DE para os machos, enquanto que AM, CO e CS foram associados por equivalência completa através do ato precedente e subseqüente DE para as fêmeas.

\subsection{Dominância e Distribuição Espacial.}

Com o intuito de se identificar variáveis intervenientes que explicassem as diferenças freqüenciais e rítmicas observadas entre os animais, sexo e boxes, analisou-se as interações sociais dos animais dentro de seus espaços. A Tabela 6 representa uma matriz obtida pela soma de três comportamentos com fundo agonístico: 1) ameaça; 2) agressão; 3) evitar, para cada um dos boxes. Para sua obtenção observou-se cada um dos boxes durante duas horas por dia (15:00 às 17:00), anotando-se sempre quais eventos ocorriam e os animais envolvidos. 
TABELA 6 - Matriz de comportamentos agonísticos entre os animais do box A.

\begin{tabular}{rr|r|r}
\hline ANIMAIS & Fêmea 1 & Fêmea 2 & Macho 2 \\
\hline Fêmea 1 & 0 & 16 & 118 \\
\hline Fêmea 2 & 0 & 0 & 20 \\
\hline Macho 2 & 3 & 0 & 0 \\
\hline
\end{tabular}

Pela matriz obtida identificou-se a possível posição hierárquica de cada um dos animais dentro deste grupo. Desta forma, quanto ao box $\mathrm{A}$ pode-se dizer que a fêmea 1 dominou a fêmea 2 e o macho 2 . A fêmea 2 dominou o macho 2. O macho 2 interagiu com a fêmea 1 (em menor freqüência), mas não interagiu com a fêmea 2.

TABELA 7 - Matriz de comportamentos agonísticos entre os animais do box $B$.

\begin{tabular}{rr|r|r}
\hline ANIMAIS & Fêmea 3 & Fêmea 4 & Macho 1 \\
\hline Fêmea 3 & 0 & 1 & 7 \\
\hline Fêmea 4 & 15 & 0 & 53 \\
\hline Macho 1 & 20 & 7 & 0 \\
\hline
\end{tabular}

Quanto ao Box B, a matriz da Tabela 7 mostrou que a fêmea 4 dominou a fêmea machucada 3 e o macho 1 , sendo que este dominou a fêmea 3, apesar desta ter interagido com o macho e este ter interagido com a fêmea 4 , porém sempre em menor freqüência.

Dado o posicionamento hierárquico, observou-se para cada box o que ocorreria com o espaço ocupado para cada animal. Observou-se que preferencialmente os animais se deslocavam ao longo de uma das três paredes livres para esta atividade, uma vez que a quarta parede estava tampada por uma tela para permitir que os animais permanecessem sempre em foco durante as filmagens. Outro ponto de deslocamento, era justamente uma diagonal oposta ao vértice das duas paredes, acompanhando o vértice tampado com a tela. Com o bebedouro ocupando a posição central do box, só era permitida a passagem de no máximo dois animais pelas retas formadas. Desta forma o "circuito", isto é a área livre para deslocamentos de cada box, adquiriu uma forma triangular, permitindo a passagem de dois 
animais ou circular em torno do bebedouro só permitindo o trajeto de um dos animais.

O comedouro ocupava uma posição importante na relação entre os animais e o espaço. À primeira vista tudo girava em torno do comedouro. Todos os animais foram freqüentemente ao cocho e apresentaram um surto de ingestão. A relação de dominância nos boxes dos animais se tornou óbvia, com apenas a relação entre a fêmea machucada e o macho não tão clara. Enquanto a fêmea dominante estava comendo, ela permitia a aproximação de um dos dois animais, a outra fêmea ou o macho, do cocho para alimentar-se. Quando a dominante interrompia o surto de alimentação optava pela expulsão do outro animal do cocho ou iniciava o deslocamento (DE), deixando que um dos outros animais se alimentassem. Voltando de uma atividade, a fêmea dominante se aproximava do cocho, onde as aves "subalternas" se alimentavam, ambas as aves se afastavam para dar lugar ao dominante, uma delas podia voltar após a dominante iniciar a ingestão.

No Box $B$, a relação junto ao comedouro entre o macho e a fêmea machucada foi diferente, pois o macho se afastou do cocho em diversas ocasiões com a proximidade da fêmea 3, apesar do inverso ter acontecido com maior freqüência. A fêmea 3 passou um tempo maior sentada e parecia preferir um local próximo ao cocho, encostada a uma das paredes.

Quanto aos deslocamentos (DE), a fêmea dominante raramente desviava seu trajeto, se outro animal estivesse se deslocando simultaneamente, estes que se desviavam, fazendo um semicírculo no animal dominante, ou mudando de direção seu deslocamento. Quando os subalternos ou apenas um deles estavam sentados ou parados mas em atividade, raramente eram agredidos pela dominante, e este no seu deslocamento podia passar ao lado. Geralmente estes animais estavam executando arrumação (AR), coçar (CÇ) ou mesmo banho de pó (BP), e a tolerância do animal dominante nestas ocasiões parecia ser maior. 
Notável, entretanto foi o grande medo do macho em relação às fêmeas. O medo foi evidenciado através das reações de fuga exacerbadas e com velocidade bem superior à outra fêmea frente às situações agonísticas. Infelizmente, não se conseguiu observar nenhuma oviposição e apenas quatro atos (box A) relacionados ao acasalamento. Destes quatro, um ocorreu entre um macho e uma fêmea, a fêmea 1 estava sentada e de repente o macho se aproximou e montou. Nas outras três de maneira semelhante a fêmea 2 estava sentada e a fêmea 1 se aproximou e montou.

\section{DISCUSSÃO}

As atitudes dos homens frente às aves domésticas diferem das adotadas com relação aos mamíferos de produção (ovinos, caprinos, bovinos, suínos, etc.). As galinhas, por exemplo, são raramente vistas como um indivíduo, e poucas pessoas creditam uma habilidade intelectual a elas. LIEBERMANN (1936) cita que, na sua época as pessoas acreditavam que os tinamídeos não possuíam inteligência, pela falha em se adaptar às condições de criação de outra espécie, a galinha.

Estas atitudes são em parte conseqüência do grande número de animais que são criados por unidade de área e em parte por serem aves e os homens não conseguirem identificá-las individualmente, como faz corriqueiramente com os grandes mamíferos. Estas atitudes em relação às galinhas, e em continuidade a outras aves, tem tido uma considerável influência, pelo menos a nível anedótico, sob a capacidade do homem em reconhecer quais as condições que estes animais precisam, e quais tratamento eles toleram. 
A forma das pesquisas em avicultura mudou muito nos últimos anos. Ao intensificar a criação de aves de postura, a pesquisa zootécnica focou-se na avaliação do efeito da distribuição espacial sobre a mortalidade e produção, uma vez que no passado as considerações econômicas eram as principais (HUGHES 1975a, ZAYAN 1985 e NEWBERRY 1993). Infelizmente, a maioria destes trabalhos eram confusos, pois não havia um controle para o tamanho do grupo. Colocando-se um diferente número de animais num mesmo espaço, na verdade o que se estava investigando era a densidade de estoque. Mais recentemente, os modelos experimentais tem sido sistematicamente controlados para o tamanho de grupo e o espaço por ave (DOYEN \& ZAYAN 1984), além de uma preocupação crescente sobre o bem estar animal, trouxeram técnicas de outras áreas de pesquisa como por exemplo os testes de preferência (DAWKINS, 1981 e NICOL, 1986), técnicas operantes (LAGADICE \& FAURE, 1987; FAURE 1994, KEELING, 1995) e de observação (LEHNER, 1992) da psicologia experimental e da etologia, para o conhecimento de aspectos tais como as necessidades de espaço, interações sociais, entre outros.

\subsection{Freqüências temporais}

O principal objetivo deste trabalho foi alcançado, conseguiu-se registrar para a perdiz a distribuição temporal de seus comportamentos mais representativos. Espera-se que estes dados sirvam de referência para futuros trabalhos que poderão acessar desta forma, mais facilmente, o efeito de seus tratamentos. Particularmente, seria interessante verificar o efeito da lotação sobre o comportamento, a exemplo de CHANNING et al.(2001), que usando uma densidade constante testou poedeiras em 5 lotações diferentes observando que apesar da lotação não ter afetado a distribuição espacial, à medida que subia a lotação as aves ficavam um tempo maior em pé e mostravam menores freqüências de ingestão. Assim, um benefício adicional de quantificar o comportamento é de ranquear-se a atividade de acordo com as quantidades de tempo nelas gasta. 
No contexto de bem estar, as atividades dominantes são de grande importância. Para as aves de corte por exemplo, o sentar predomina, com muito deste tempo gasto em ociosidade ou dormindo. Assim, é importante para estas aves que elas estejam confortáveis, com um bom material de cama e que não haja problemas associados com as altas taxas de sentar. As aves de corte são caracterizadas como raças de aves extremamente inativas, bem distante dos seus ancestrais da floresta.

Algumas alterações observadas na distribuição temporal estão diretamente ligadas com a intensiva seleção genética para crescimento rápido e melhor conversão alimentar, outros parecem ser mais uma conseqüência de alterações fisiológicas e morfológicas do que alterações motivacionais. O continuar da seleção foi agravando os problemas destas linhagens, e serve de aviso para não repetir-se a história com mais uma espécie animal, no caso as perdizes.

Para as perdizes as categorias comportamentais que apresentaram as maiores porcentagens de freqüência nas horas observadas em ordem decrescente foram: deslocamento (DE), ciscar (CS), comer (CO), parado (PA), arrumar (AR) e sentado imóvel (SP), esta última com restrições devido à fêmea machucada, a qual apresentou a maior porcentagem de ocorrência para o comportamento parado (PA, 62\%).

Com linhagens de frango de corte e ainda com um sistema de ração restrita, liberada apenas uma vez por dia, KOSTAL et al. (1992) relata que as aves ocuparam mais tempo parado, deslocando, ciscando e tomando banho de pó, e em atividades ligadas ao bebedouro e ao comedouro vazio.

As alterações genéticas sofridas pelas raças de corte, podem ser acessadas indiretamente pelo uso das alterações nas distribuições temporais do comportamento. Os altos níveis de sentar estão relacionados 
com o peso corporal e com as rápidas taxas de desenvolvimento corporal das raças de corte (WEEKS et al. 1994; BESSEI 1992). Em 1980 as médias na literatura eram de $64 \%$ a $73 \%$ do tempo sentado (MURPHY \& PRESTON 1988, NEWBERRY et al., 1988) e em 1992 encontramos 80-90\% do tempo (BESSEI, 1992; WEEKS et al., 2000). A seleção para melhorar a eficiência da conversão alimentar inevitavelmente favorece os animais menos ativos.

Outra grande prova da alteração comportamental em função da seleção é o tempo gasto em atividade de ciscar (WEEKS et al., 2000). O tempo observado para aves de corte $(3 \%)$ é dramaticamente menor dos que os obtidos para as galinhas selvagens (60\%) e decai ainda mais nas aves com laminite. WEEKS et al. (2000), apresenta um trabalho comparando aves de linhagens de corte sadias com as que mostram inflamação nas patas (laminite), a grande freqüência com que este mal atinge as aves de corte é vista como uma conseqüência da seleção. O tempo gasto pelos animais sadios sentados foi de $76 \%$, aumentando para $86 \%$ nos animais com laminite. O sentar aumenta com a idade. Os animais sadios ficaram mais tempo em pé $(7 \%)$, na arrumação $(3,5 \%)$ e comendo $(4,7 \%)$. Os deslocamentos ocuparam $3,3 \%$ do tempo, caindo para $1,5 \%$ no caso das aves com laminite; é provável que este tempo seja próximo ao mínimo necessário para o acesso aos recursos como comida e água. Enquanto as aves sadias alimentam-se 50 vezes em 24 horas, as aves comprometidas visitaram apenas 30 vezes. Entretanto a duração da refeição é ajustada para não dar diferenças no tempo gasto em comer por dia. O tempo gasto bebendo foi o mesmo para todas as aves (3\%). As alterações na distribuição temporal em particular com a redução nas atividades executadas em pé e as diferentes estratégias de alimentação adotadas são consistentes com um custo maior imposto pela laminite em detrimento do bem estar destas aves.

A fêmea de perdiz machucada, à semelhança das aves com laminite, mostra uma redução na porcentagem de freqüências de alguns comportamentos quando comparada com as médias mais elevadas dos 
animais sadios: deslocamento (26\%); parado (13\%); comer $(5 \%)$; ciscar $(17 \%)$ e arrumar $(14 \%)$.

\subsection{Comer}

A alimentação no escuro para as aves domésticas, pode ocorrer apenas havendo iluminação intermitente, mas é excepcional com fotoperíodos de 8 horas ou mais. Uma revisão na literatura mostra que as aves geralmente comem mais no começo ou ao final do dia ou em ambos , mas não no meio do dia.

A forma de como a ingestão é organizada de hora em hora, através do dia, pode fornecer informações sobre as mudanças fisiológicas internas e sobre os mecanismos envolvidos no controle de consumo dos alimentos. Nas aves domésticas existe uma grande variabilidade nos padrões de alimentação diurna descritos na literatura. Numa revisão, SAVORY (1980) agrupa os padrões de alimentação em 5 grandes grupos, as aves que se alimentam a uma taxa constante através do dia e não mostram um ritmo diurno, as que se alimentam mais ao início do dia, as que se alimentam mais no meio do dia do que ao início ou final do dia, as que se alimentam mais no começo e final do que no meio do dia e as que se alimentam mais ao final do dia.

Observou-se que, para as perdizes, os machos tendem a se alimentar ao meio do dia, enquanto que apenas a fêmea 1 apresenta surtos de comer ao meio do dia. Ambos os machos têm um comer mais acentuado ao final do dia, enquanto que para as fêmeas, apenas a fêmea 3 apresenta este padrão. A fêmea 4 mostra uma freqüência maior de surtos de comer no período matutino, enquanto as fêmeas 1 e 2 têm suas freqüências de surtos de comer distribuídas ao longo do dia. 
Pode-se discutir com SAVORY (1980) a significância de diferentes padrões de alimentação. Quando o pico de alimentação ocorre ao fim do dia, os animais armazenam comida no papo para durar durante a noite (IRVING et al. 1967) e se ingerirem alimento suficiente, terão menos fome e não precisarão ingerir alimento logo pela manhã. Ao contrário, as aves que não enchem o papo ao entardecer ficaram com seus tratos digestivos vazios à noite e estarão famintas pela manhã, comendo basicamente neste horário.

Assim, em galinhas poedeiras que tendem a encher seus papos à tarde, a motilidade do estômago permanecerá alta através da noite, enquanto que as aves que não fazem postura tendem a comer menos a tarde e cessar durante a noite (ROCHE \& DECERPRIT 1977). Isto implica que a quantidade de comida ingerida ao final do dia seja o fator determinante do padrão mostrado. Esta conclusão é ainda suportada pelo fato de que quantidades de comida ingeridas na primeira e nas últimas duas horas de luz são negativamente correlacionadas. Segundo SAVORY (1976b), as aves com pico de alimentação ao final do dia consomem mais alimentos em um dia do que as com pico matinal.

O pico de alimentação à tarde mostrado pela maioria das aves de postura pode ser um resultado direto do tempo de oviposição e/ou de formação do ovo. Para as aves que não estão em postura e apresentam um pico de alimentação no final do dia, é fundamental que sejam capazes de predizer quando seu dia terminará, e a variação na habilidade para fazer isto pode ser responsável por parte da diferença observada no padrão de ingestão. Presumivelmente este comportamento depende de um relógio interno (BUNNING, 1964) e existe evidência que precisa ser aprendido. Em pintinhos que mostram picos de ingestão à tarde, este padrão leva de 3 a 4 semanas para se manifestar e eles não mostram ou mostram pouca periodicidade na primeira e segunda semana de vida (ASAHIDA \& MINURA, 1972). Aves vivendo em luz natural, que sabem quando seu dia terminará, geralmente têm um pico de ingestão ao entardecer, independente de quando 
estão em postura ou não (WOOD-GUSH, 1959; SAVORY et al. 1978). Nas aves, mudanças regulares entre luz e escuro atuam como o mais potente estímulo ou ZEITGEBER, para regular ritmos de atividade locomotora, temperatura corporal, taxas cardíacas e respiratórias, tempo de oviposição e alimentação (WILSON et al.,1964, CAIN \& WILSON, 1974, OSHIMA et al., 1974 ; BALLARD \& BIELLIER, 1975; BHATTI \& MORRIS, 1978). Em aves que apresentam um pico de alimentação ao fim do período de luz, quando submetidas a intermitência no regime de luminosidade o acender a luz tornase o principal sinal para iniciar-se a ingestão de alimento, no período de transição até a próxima fase escura (BALLARD \& BIELLIER, 1975; BHATTI \& MORRIS, 1978). Em luz contínua, as aves se alimentam a uma taxa constante de hora em hora, mas mostram algum ritmo se existirem outros ZEITGEBERS, tais como mudanças regulares na temperatura do ar, sons ou manejos específicos (SAVORY, 1976a)

O estado reprodutivo parece ser outro importante indutor dos hábitos e padrões do comer. As diferenças encontradas entre as aves de postura e as de não postura podem simplesmente refletir os requerimentos de alimentos associados a formação do ovo. Assim, as aves de postura encheriam seus papos à tardinha porque precisam comer mais do que as aves de não postura. Mais especificamente, as aves de postura necessitariam comer mais nos dias de formação dos ovos, do que nos dias de não formação (MORRIS \& TAYLOR 1967) e isto pode explicar porque as galinhas individualmente podem mostrar diferentes padrões de alimentação nos diferentes estágios do seus ciclos de postura (WOOD-GUSH \& HORNE 1970; HUGHES, 1972). Entretanto, esta explicação é insatisfatória, porque embora as aves de postura geralmente comam mais de manhã, elas irão comer ao final do dia em situação de luz natural, ou quando o entardecer for simulado (SAVORY, 1976b). Isto sugere que as aves preferem evitar o déficit de comida à noite, enchendo seus papos à tarde, mas em muitos casos elas não fazem isto, porque são incapazes de predizer quando o dia vai terminar. Se for desta maneira que as coisas se dão, sugere-se que o 
aumento na alimentação ao final do dia pelas aves de postura pode ser um efeito direto do tempo de oviposição e ou de formação do ovo.

O consumo de alimentos declina por 2 a 3 dias antes da oviposição, especialmente na hora antes da postura, e aumenta marcantemente para uma ou duas horas imediatamente depois (DUNCAN \& HUGHES, 1975; SAVORY, 1977a). WOOD-GUSH \& HORNE (1970) concluem que a redução na ingestão é devida principalmente ao comportamento do animal antes de botar, que nos alojamentos assume a forma de um excessivo deslocamento e um aumento do sentar, dependendo da linhagem da ave (WOOD-GUSH, 1972). Em adição, o fluxo do alimento ingerido pode ser muito reduzido uma ou duas horas antes da postura (HILL \& STRACHAN, 1975), e isto pode também inibir o comer neste tempo. O aumento de ingestão após a postura é provavelmente para compensar a redução antes da postura, mas pode também ser associada à ovulação. Visto que as freqüências dos tempos de oviposição são maiores pela manhã (com 14 horas de fotoperíodo) (FRAPS, 1955; GILBERT \& WOOD-GUSH, 1971) e como a ingestão é baixa antes da postura e alta depois, esta pode ser a razão pela qual a atividade de comer nas galinhas de postura é geralmente baixa de manhã e maior à tarde.

Outra possível razão para o aumento do comer à tarde seria uma demanda específica de cálcio para a formação da casca. Quando uma dieta com baixo teor de cálcio e farinha de ostra são fornecidas separadamente em regime de luz contínua, as galinhas de postura mostram um pico de consumo da farinha de ostra, mas não da dieta com baixo teor de cálcio, quando o ovo está na glândula de formação de casca, no começo da calcificação (NYS et al., 1976). Isto indica que as galinhas de postura podem discriminar entre comida e ingestão de cálcio, sugerindo que o pico na ingestão de comida depois que o ovo entra na glândula de formação de casca, com uma dieta rica em cálcio, reflete esta especifica demanda deste mineral. Quando uma baixa dieta de cálcio e uma fonte de cálcio são fornecidas num regime com 14 horas de fotoperíodo, as galinhas de postura 
mostram um pico no consumo de cálcio no final do dia quando os ovos estão sendo formados, e um aumento no consumo de alimentos ao final do dia em que os ovos estão sendo postos (HUGHES, 1972; MONGIN \& SAUVER, 1974). Mudanças na ingestão, durante a formação do ovo, são provavelmente controladas hormonalmente. Infelizmente para as perdizes não conseguiu-se observar posturas.

Visto que as exigências nutricionais de crescimento de galinhas são relacionadas ao peso corporal, isto sugere que o aumento das taxas de crescimento das linhagens de corte são devidas mais a sua conversão melhorada do que ao aumento de ingestão ou consumo de alimento. As linhagens de corte convertem a comida em ganho de peso mais eficientemente que as linhagens de postura porque eles despendem menos tempo comendo e mais tempo descansando, e assim podem devotar mais da energia dos alimentos para o crescimento (MASIC et al., 1974; SAVORY, 1975). Nota-se isto nas diferenças entre sexo para as perdizes, apenas salientando a diferença do comportamento destas com relação aos boxes.

FUJITA (1973a), investigando o efeito do tamanho da partícula sobre a atividade do comer em poedeiras, achou que os padrões de alimentação das aves alimentadas com pellets eram mais pronunciadas do que as aves alimentadas com massas ou rações fareladas, que ficam mais tempo no cocho com este tipo de alimento. $O$ efeito do tamanho da partícula pode ser responsável para a falta de periodicidade em alguns estudos que usam ração farelada (DINGLE, 1971; FUJITA, 1973b). As perdizes, apesar de alimentadas com ração farelada, mostraram uma periodicidade de 8 horas, porém seria interessante testar a ração peletizada e verificar o seu efeito sobre os surtos de comer e seu ritmo. CROMBERG et al. (1996) mostraram que as perdizes selecionam a ração farelada, assim é de se esperar que este tipo de ração induza um maior número de surtos, uma vez que as quantidades ingeridas e a qualidade nutricional serão diferentes a cada surto. Com codorna japonesa (Coturnix japonica) ocorre o mesmo, as aves 
alimentadas com ração farelada comeram menos, gastaram menos tempo comendo, e mostraram um ritmo de atividade de alimentação mais distribuído ao longo do dia, do que outras alimentadas com a mesma ração mas diluída com celulose indigestível (VAN HEMEL \& MYER, 1969; SAVORY, 1979).

O efeito do formato da gaiola sobre os padrões de alimentação depende mais do espaço disponível por pássaro (HUGHES \& BLACK 1976,1977). Existe pouca evidência de que o ambiente social da ave cause variações no tipo de padrão de alimentação apresentado. Aves isoladas mostram o mesmo tipo de padrão alimentar do que as agrupadas, e o contato auditivo não tem um efeito óbvio de sincronizar a alimentação (SAVORY, 1980). O contato visual entretanto tem um importante efeito sincronizador sobre a alimentação, com pássaros sozinhos em gaiolas com vista uns aos outros e pássaros em grupos tendendo a alimentar-se juntos simultaneamente, em vez de separadamente como indivíduos (HUGHES, 1971). Isto não se aplica entretanto, logo após e antes da oviposição, quando a ingestão de comida de poedeiras muda marcadamente. A sincronização do comer entre os pássaros é chamada de alelomimética (HUGHES, 1971) e é devida à facilitação social (THORPE, 1956). Não existe evidência de que ela aumente o consumo de comida no curto ou longo prazo em circunstâncias normais e não planejadas (SAVORY, 1980).

Tentar explicar o padrão observado para o comer à vista do que foi até aqui exposto é um exercício interessante. Revisando os resultados podese dizer que: três animais (fêmea 3 , machos 1 e 2) têm um padrão que apresenta maior porcentagem de freqüências do comer ao fim da tarde, a fêmea 4 tem sua porcentagem um pouco mais elevada no período matutino, enquanto que as outras duas fêmeas distribuem igualmente as freqüências ao longo do dia (notadamente a fêmea 2 com um ritmo ultradiano de 6 horas). Quanto às porcentagens médias das freqüências dos surtos diários de comer, nota-se certa similaridade, à exceção da fêmea 3 machucada que 
é muito baixa, e do macho 1 muito alta. No entanto nas observações quanto ao número de surtos absolutos, observamos para a fêmea 4, uma quantidade de surtos extremamente baixa e não condizente com as observações percentuais da freqüência de surtos, indicando de forma indireta que talvez os surtos de comer para esta fêmea sejam mais longos e estaria ocorrendo uma seleção do alimento (CROMBERG et al. 1996), provavelmente esta fêmea estava selecionando as partículas maiores de milho.

A visualização destes resultados indica que as fêmeas dominantes têm maior acesso ao comedouro, e o fazem logo pela manhã. Desta forma, percebe-se que as fêmeas dominantes estão propensas a comer pela manhã provavelmente devido a uma motivação ligada à palatabilidade. No Box $B$ isto é mais visível devido à fêmea machucada, que não podendo competir, agrega seus surtos de comer mais ao final do dia, obedecendo a estratégia discutida acima, e permitindo que a fêmea 4 tenha o cocho só para ela, explicando a tendência de apresentar maior quantidade de surtos pela manhã. No Box $A$, as fêmeas competiriam para comer juntas, explicando a distribuição desta atividade por igual ao longo do dia, uma vez que ciclos de postura e de ovulação não estiveram em curso, é provável que estes padrões mudem com estas novas variáveis. Quanto aos machos o grande medo que demonstraram às fêmeas explica a maior freqüência de surtos de comer ou o maior número de idas ao comedouro quando estas o deixavam livre, próximo às 18:00 horas.

\section{3 Dominância e o uso do espaço}

O processo gradual pelo qual homem e animais ficaram em contato íntimo resultou nos sistemas de manejo, que são um compromisso entre os requerimentos do homem e os requerimentos dos animais. Se considerarmos a exposição de BUDIANSKI (1992) de que os animais inicialmente escolheram a domesticação, pode-se concluir que sua aptidão 
biológica e provavelmente seu bem estar, foi aumentado pela forma com que o homem lidava com eles no passado. Entretanto, o processo contínuo de domesticação quebrou a ligação tênue que previamente existia entre aptidão e bem estar. Na moderna zootecnia, o sucesso reprodutivo dos animais domésticos deixados para reprodução é indubitavelmente muito maior do que o alcançado na natureza, porém, no que diz respeito ao bem estar ele é mais pobre. Assim, não é mais apropriado usar a palavra ótimo no sentido de maximizar a aptidão biológica do indivíduo pela melhor relação entre custos e benefícios para aquele indivíduo. Nas condições de criação atual esta palavra é usada para descrever a melhor relação entre o custo do bem estar do animal e os benefícios financeiros para o criador. A discussão que assistimos entre criadores e pesquisadores ou a sociedade preocupada com o bem estar sobre a alocação espacial indica que não chegamos ainda a um acordo sobre o que seja um ótimo de bem estar para os animais sob nosso controle (KEELING, 1995).

Fica difícil alojar um animal num local que seja menor do que ele, se bem que muitas vezes aproximar-se deste limite inferior (por exemplo, gaiolas maternidade para porcas). Entretanto, calcular através de experimentos o espaço físico necessário pode ser um ponto de partida lógico na ausência de conhecimentos que indiquem quanto espaço o animal vai precisar para conseguir executar suas atividades. Multiplicar os valores individuais pelo número de animais de um grupo, também tem sido feito, mas neste caso tem-se que considerar os requerimentos desta situação de grupo. Um espaço adicional é requerido para permitir que os animais interajam ou evitem-se uns aos outros (MCBRIDE, 1971). Os primeiros pesquisadores cunharam os termos distância individual e espaço pessoal para o espaço requerido acima ou abaixo do adequado espaço físico (HEDIDER, 1955; MCBRIDE, 1971). O espaço pessoal é usado com referência a uma área ao redor do indivíduo a qual ele tenta deixar livre de coespecíficos. A distância individual é a distância do sujeito ao perímetro do seu espaço pessoal, e corresponde à distância mínima que um animal 
permitirá que outro se aproxime de uma direção em particular antes que responda agressivamente, detendo a aproximação ou movendo-se e evitando a aproximação e mantendo a distância. Efetivamente a hipótese de espaçamento comportamental implica que cada animal se moveria dentro de uma "bolha" que ele tentaria deixar livre de outros indivíduos.

Experimentos medindo o nível de agressão entre aves a diferentes distâncias inter-individuais não obtiveram sucesso na determinação das dimensões do espaço pessoal e lançou dúvidas sobre a validade do conceito (KEELING, 1995). Entretanto, o termo continua popular e sabe-se que as dimensões variam de acordo com a atividade do animal, sua posição na escala de dominância e que o espaço pessoal não é circular, mas maior em frente a cabeça (MCBRIDE, 1971). Hoje conseqüentemente, as pesquisas têm sido feitas medindo-se as distâncias entre os indivíduos, resultando o espaço comportamental e os requerimentos espaciais sendo considerados uma característica do grupo e assim integralmente ligada à organização do grupo (ZAYAN \& DOYEN, 1985; KEELING \& DUNCAN, 1989; KEELING, 1994).

Uma multidão é um termo subjetivo, mais subjetivo do que densidade de estoque e implica numa percepção de espaço pelo animal. A interferência social, numa forma de competição ou de dificuldade de coordenar atividades é considerada um dos maiores fatores de influência quando um indivíduo percebe uma área repleta de outros semelhantes (STOKOLS, 1972). Esta aglomeração de indivíduos esta além de uma interação espacial, social e de fatores internos.

Os fatores que influenciam o modo de como os indivíduos de uma determinada espécie posicionam-se em relação uns aos outros, inclui o risco de predação e distribuição da comida e outros recursos, embora o parasitismo e as transmissões de doenças sejam também importantes. Assim, a questão de porquê os animais não se distribuem randomicamente 
pode ser vista como funcional. Entretanto, na situação de criação são as influências de curto prazo que apresentam o maior interesse. É importante lembrar que, as questões causais e funcionais estão ligadas, e assim mesmo, os fatores de curto prazo influenciando o espaçamento tem conseqüências evolucionárias.

A posição relativa dos animais na posição hierárquica pode influenciar a distribuição espacial. KEELING \& DUCAN (1991) mostraram um efeito significativo do rank sobre a distância inter-individual, com as maiores distâncias ocorrendo entre os animais mais altos da escala e os mais baixos. Realmente, os machos de perdizes encontravam-se mais afastados da fêmea dominante. McCORT \& GRAVES (1982) sugerem que a dominância hierárquica providencia um meio pelo qual um possível recurso limitado, como por exemplo o espaço pessoal, pode ser diferencialmente alocado aos membros do grupo. KEELING (1995) questiona a afirmação, se o espaço é um recurso "per se", a vantagem de se ter um espaço individual (se isto existir) seria a de flexibilizar o seu uso para se obter prioridade de acesso para outros recursos. Assim, não é o espaço que é importante mas o potencial de se obter o que existe neste espaço.

Vários estudos (MANKOVICH \& BANKS, 1982; KEELING \& DUNCAN, 1989) mostram que as aves se orientam entre si distâncias interindividuais pequenas e evitam-se a longas distâncias. Conforme exposto para as perdizes, quando perto, os animais parecem se tolerar mais do que foi visto nas constantes mudanças de caminho ou desvios, quando estão se deslocando simultaneamente. As aves têm um sistema binocular de visão e têm que se virar em direção a um objeto ou outra ave de forma a julgar corretamente sua distância. Entretanto, a orientação para outra ave pode ser vista como uma forma branda de ameaça, e pode-se propor que a distância inter-individual em que uma ave muda sua orientação é quando o espaço pessoal da ave esta sendo invadido. Esta é provavelmente a única evidência de que este espaço existe. $O$ interessante disto é que esta distância varia de 
acordo com a quantidade de espaço disponível para as aves. KEELING \& DUNCAN (1989) encontraram um grupo de 3 poedeiras com uma distribuição espacial de $1408 \mathrm{~cm}^{2}$ por ave, as aves mudavam sua orientação a uma distância inter-individual média de $0,25 \mathrm{~m}$; com as aves alojadas a $5633 \mathrm{~cm}^{2}$ por aves, esta distância aumentava para 0,35 m. MANKOVICH \& BANKS (1982) achou que para um grupo de 5 poedeiras, com $7500 \mathrm{~cm}^{2}$ por ave a distância era de $0,75 \mathrm{~m}$. Para as perdizes, na situação observada estimou-se que esta distância era de 0,30 a $0,40 \mathrm{~m}$ e possivelmente era maior no box $B$ onde existia o animal doente e sendo o espaço disponível aos outros animais, maior.

Esta tendência de mudança de orientação a uma distância interindividual menor quando as aves são colocadas num espaço menor, pode implicar numa adaptação aos espaços reduzidos. Talvez exista uma tolerância dos indivíduos dominantes à aproximação de outros ou que o medo se reduza em indivíduos subalternos à proximidade de outros, mas deve existir um limite a esta adaptação, se ela existir. Nas perdizes é notória a diferença de interações agonísticas entre os boxes. O macho 2 que habita o box onde teoricamente mais espaço esta disponível, sofre um número menor de interações. À medida que o tamanho do box diminui para pequenos grupos de aves, os indivíduos usam mais os cantos (KEELING \& DUNCAN, 1989) ou a periferia (STRICKLIN, 1975). É sob estas circunstâncias que a dominância parece ser mais óbvia, demonstrando-se que as poedeiras subordinadas passam mais tempo no canto do que as dominantes (KEELING \& DUNCAN, 1989).

Relatou-se para as perdizes que, a distância inter-individual, variou de acordo com a atividade executada, notadamente para a arrumação, o que é demonstrado também para as poedeiras (KEELING \& DUNCAN, 1991; KEELING, 1994) assim, pode-se prever com algum grau de precisão, quando um indivíduo tem maior chance de mover mais próximo ou separado em associação com a mudança de atividade. A ordem de distância inter- 
individual da maior para a menor, de acordo com a atividade desempenhada seria comer (CO), deslocar (DE), parado (PA), e ciscar (CS), que é executada à menor distância inter-individual.

A relação entre a área do grupo e o risco de predação tem sido investigado (HAMILTON, 1971; MYERS, 1984). Para o mesmo grupo o aumento no risco de predação pode dar-se de duas maneiras, a primeira é aumentando o número de predadores e a segunda se os indivíduos ficarem mais vulneráveis. Certas atividades expõem mais os animais, por exemplo, enquanto fazem a arrumação as aves fecham seus olhos, assim deve ser benéfico ter na proximidade outras aves quando esta atividade estiver sendo executada. Assim, a vulnerabilidade à predação atua para trazer mais próximo os indivíduos, quando estão executando atividades que os deixam mais vulneráveis. Mas a competição por recursos e provavelmente a baixa probabilidade de encontrar-se recursos numa área já pesquisada por um coespecífico, atuará de forma a deixar os indivíduos separados (forrageamento). Desta forma, pode-se ver o espaçamento como uma forma de balanço entre as tendências de aproximar-se ou afastar-se dos coespecíficos. Esta forma de explicar a organização espacial como um balanço antagônico entre as tendências tem sido proposto a longa data por SCHNEIRLA, (1959).

\subsection{Comportamentos anormais}

Para reconhecer que um comportamento é anormal, o observador precisa estar familiarizado com a variação do comportamento normal da espécie em questão. Uma das qualidades de um bom criador ou de seu empregado é justamente sua habilidade em identificar um comportamento anormal a partir do seu conhecimento adquirido pelo olhar atento aos seus animais. A dificuldade surge quando para estas pessoas o comportamento aparece na maioria dos animais e esta situação leva a julgá-la como uma situação normal. Um largo conhecimento do repertório deste animal é 
necessário na tentativa de se estabelecer o que é a normalidade. Um extensivo conhecimento da biologia do animal e uma detalhada investigação ecológica são necessárias para decidir se o comportamento é anormal (FRASER \& BROOM, 1990).

Em aves, quando ocorre algum tipo de restrição ambiental é comum o surgimento de alterações comportamentais (KOSTAL et al., 1992). Aves poedeiras criadas com restrição alimentar (55 a $75 \%$ a menos de ração) tendem a ser mais ativas e algumas delas despendem mais tempo em atos estereotipados direcionados a objetos sem ligação com a comida como o bebedouro ou a parede do viveiro. Não há evidências de estresse com o fato de redução da ração medidos ou julgados através de índices fisiológicos (GROSS \& SIEGEL, 1983). SAVORY et al. (1992) relata entretanto, que o bicar estereotipado é suprimido com o tratamento com antagonistas dos receptores peptídicos-opiódicos centrais. Sugere-se que a liberação de opióides pelo SNC durante o comportamento estereotipado pode ser reforçado positivamente e acalmar o animal e assim este comportamento pode representar uma estratégia bem sucedida de enfrentar ou aliviar o estresse causado pela restrição alimentar. Evidências de que as atividades estereotipadas espontâneas têm propriedades de reduzir o estresse vem de trabalhos com ratos (BRETT \& LEVINE, 1979; DANTZER et al., 1988), porcos (DANTZER \& MORMEDE, 1983) e com gado (WIEPKEMA et al., 1987).

O aumento marcante nos deslocamentos e ficar em pé na hora imediatamente anterior à distribuição da comida implica que as aves antecipam este evento como outros, como a luz (TWIEST \& SMITH, 1970; SAVORY 1980). O aumento do deslocamento antes do comer é similar ao aumento da atividade locomotora, algumas estereotipadas, mostrada por vários mamíferos cativos anteriormente às suas refeições diárias (EVANS, 1971, MISTLBERGER \& RUSAK, 1987; MASON, 1990) e presumivelmente reflete a expressão de um comportamento de forrageamento. Enquanto o 
aumento do deslocamento antes do comer não aparece estereotipado neste experimento, as atividades de bicar que surgem logo após o comer, e perduram pelo dia, satisfazem o critério de ODBERG (1978), definindo estereotipia como similaridades morfológicas, repetidas e aparentemente sem função. Estereótipos oralmente direcionados foram observados em outras espécies com restrição alimentar e também tinham seu inicio após o horário de alimentação (PALYA \& ZACNY, 1980; JENSEN, 1988) e todas estas atividades presumivelmente refletem frustração do componente consumatório da alimentação (DUNCAN \& WOOD-GUSH, 1972; RUSHEN, 1985).

Apesar do exemplo usado acima refletir uma estereotipia, outros comportamentos anormais são passíveis de ocorrerem. Níveis baixos ou muito altos de responsividade são também consideradas anormalidades comportamentais. As causas apontadas para estas muitas vezes, são desordens neurológicas específicas, mas na maioria das vezes elas são inadequações do sistema de criação ou das condições de alojamento (FRASER \& BROOM, 1990).

Mesmo considerando frangos de corte como animais sedentários e as perdizes como animais muito ativos, a diferença entre as porcentagens para deslocamento é muito discrepante: 3,3\% do tempo para as aves de corte e até $34 \%$ das freqüências observadas para a perdiz (macho 1). Acredita-se que este comportamento apresenta características de uma hiperatividade, infelizmente apenas as observações nas condições deste trabalho, não foram suficientes para afirmações categóricas, mas foram suficientes para sugerir sua possibilidade. O deslocamento está associado a várias outras atividades, conforme mostrado através das árvores de análise seqüencial e ligado a outros comportamentos como a fuga nas interações agonísticas, estes também registrados em grande número. Assim, parece que dois fatores podem estar desencadeando o surgimento das alterações comportamentais observadas. O primeiro fator, seria o espaço disponível 
aos animais, atuando isoladamente ou em conjunto com o outro fator, que seria o atual sistema de acasalamento de $2 \%$ para $10^{\circ}$, que nas condições atuais de cativeiro é um indutor de estresse, e a alta taxa de deslocamento, associados a altos surtos de comer e de deslocar nos encontros agonísticos é uma possível evidência disto.

\subsection{Comportamentos agonísticos}

A perdiz vive num ambiente de densa vegetação e esta, pelo menos através da audição, está em contato com vários vizinhos durante parte do dia. WEEKS (1973) acredita que as altas densidades populacionais do cativeiro afetam o sistema de dominância mudando sua dominância territorial para uma dominância individual. Este autor observando os comportamentos agonísticos da perdiz em uma situação em que seis animais (sexos não mencionados, porém mais de dois machos e duas fêmeas) estavam alojados em um galpão de $6,4 \mathrm{~m}$ por $30,5 \mathrm{~m}$, relata que a maior freqüência de encontros agonísticos foi dos machos exibindo agressões em direção as fêmeas, com baixas ocorrências e em níveis semelhantes para interações entre machos, entre fêmeas e entre fêmeas e machos. Estes resultados são totalmente opostos aos observados neste trabalho. Pois as observações mostraram que as fêmeas batem nos machos a ponto deles mostrarem reações de fuga extraordinárias à aproximação destes animais. Por outro lado, para WEEKS (1973), esta agressividade seria uma indicação da persistência da fêmea em ficar junto aos machos agressivos, o que ocorreria periodicamente através da estação de acasalamento. A resposta à ameaça e à alta taxa desta, pode ser um estímulo sexual à fêmea para escolher quem seguir.

Um dos fatores que poderiam estar produzindo resultados tão discrepantes neste caso poderia ser o espaço disponível por ave no recinto. Dificilmente, para quem observou a intensidade das agressões e fugas das fêmeas em relação aos machos, esta situação poderia se inverter. O espaço 
reduzido e o sistema de acasalamento aumentam a tendência de proteção dos recursos pelas fêmeas, exacerbando os deslocamentos e as freqüências do comportamento de comer e agonísticos. No box $A$, a presença de duas fêmeas impedem a manifestação do macho, no box $B$ devido à fêmea doente, o macho tem condições de mostrar um certo grau de agressividade dominando a esta. Este aumento na agressividade segundo o relatado por WEEKS (1973), poderia explicar os altos valores de correlação entre diversos comportamentos com a fêmea 4, ela estaria acompanhando o macho como descrito a pouco. Desta forma, apesar de poder-se afirmar que o espaço disponível para os animais no box $B$ é maior do que no box $A$, por causa da fêmea 3 que fica muito tempo imóvel, não seria isto que estaria controlando a situação, e sim a possibilidade do macho manifestar sua agressividade.

\subsection{Comportamento reprodutivo}

A origem do estresse dos animais no atual sistema, pode estar associado à impossibilidade dos animais de executarem seu repertório comportamental, notadamente no que diz respeito à corte e acasalamento. Apesar de não se ter observado nenhum destes comportamentos, recorremos a literatura.

CRAVINO (s.d.), descreve o acasalamento para animais em cativeiro, que começa com manifestações de agressividade entre os machos que estabelecem rapidamente uma hierarquia. $O$ cortejo se inicia com piados entre macho e fêmea, giros e voltas ao redor e algumas bicadas no vazio. $\mathrm{O}$ macho apóia o tarso sobre o piso e bate no solo, instalando-se junto à fêmea que se mostra receptiva agachando-se (duração do cortejo 30 minutos). 0 macho sobe e copula por um ou dois minutos. WEEKS (1973) descreve um comportamento diferente: o macho dominante fica bastante agressivo em direção a uma das fêmeas, durante um ou dois dias, então ele passa a ser menos agressivo e apresenta surtos de piar (chamado) ou se aproxima e 
segue a fêmea, à qual os atos agressivos eram direcionados. Fica com a fêmea inclusive comendo, este comportamento de seguir muda rapidamente para o de cópula. Sugere ainda, que é o macho que escolhe o local do ninho e o faz com ajuda da fêmea, tal como descrito por BARTLETT (1868) e por BLAAUW, (1896). Após 24 horas a fêmea coloca os ovos e neste espaço de tempo se aproxima e segue um macho, ela não vai para o ninho fazer a postura se não estiver acompanhada por um macho. Duas fêmeas podem entrar juntas no ninho para botar (a duração da oviposição é de 11 minutos). No cativeiro é raro o macho dominante chocar, o submisso é quem choca (20 a 21 dias de incubação).

$\mathrm{Na}$ natureza, supõe-se que o comportamento se dê da seguinte forma: Quando um macho de tinamídeo está receptivo ao acasalamento, ele atrai as fêmeas para o seu território através de seus chamados. De tempos em tempos, uma fêmea se aproxima, e aceita o pareamento e a cópula. Depois ela o deixa imediatamente e irá visitar outros machos das redondezas. Um vez que ela estiver pronta para postura, ela responde a um convite de qualquer macho com quem ela abandonará seu primeiro ovo, antes de partir. Ela recomeçará este ciclo após o primeiro ovo, para o segundo e assim sucessivamente. Cada macho recebe um ovo posto por uma fêmea diferente, o qual ele incubará e cuidará.

Comparando as descrições notadamente com o que se espera ocorrer na natureza, percebe-se a impossibilidade dos animais em cativeiro desempenharem estes comportamentos. Em primeiro lugar, os machos não podem atrair as fêmeas mais receptivas com o seu piado; em segundo as fêmeas só podem se acasalar com o macho disponível no recinto; em terceiro, neste estudo, as dificuldades do macho em mostrar agressividade pode fazer com que a fêmea não seja sexualmente estimulada ao acasalamento. Ao mesmo tempo, as fêmeas em cativeiro podem ouvir os piados de outros machos, mas não terem condições de responder. Acreditase que todos estes fatos contribuem para a manifestação de frustração que 
se manifesta na hiperatividade sugerida para o deslocamento associado às duas categorias funcionais: o comer e os comportamentos agonísticos.

\subsection{Eficiência da postura}

Um outro ponto que motiva a afirmação de que os modelos seguidos do sistema de acasalamento têm problemas: são as baixas taxas de sucesso reprodutivo encontradas. Revisando a literatura, os índices obtidos por BUMP \& BUMP (1969) para ovos coletados na natureza mostraram que nesta situação a eficiência reprodutiva é aceitável, de 114 ovos coletados de ninhos selvagens apenas 6 não estavam férteis mostrando que mesmo na natureza falhas na fertilização ocorrem. Dos 108 ovos de procedência silvestre incubados artificialmente 95 eclodiram (88\%). Já os números apresentados por CARNIO (1993) para aves criadas em cativeiro com ovos incubados artificialmente, indica problemas para esta situação, este autor verificou para 475 ovos, índice de fertilidade de $49,26 \%\left(\mathrm{n}^{\circ}\right.$ de ovos férteis $/ \mathrm{n}^{\circ}$ total de ovos incubados), eclodibilidade de 52,13\% ( $\mathrm{n}^{\circ}$ de nascimentos $/ \mathrm{n}^{\circ}$ total de ovos férteis) e $25,7 \%$ de nascimento $\left(n^{\circ}\right.$ de nascimento $/ n^{\circ}$ total de ovos incubados). CRAVINO (s.d.) também não conseguiu repetir os bons resultados da natureza, em condições de cativeiro obteve eclosão que variou entre 35 e 70\%. MORO (comunicação pessoal) em situação semelhante à descrita neste trabalho conseguiu taxa de nascimento entre $18 \%$ para o ano de 1999 (209 ovos) e 14\% para a estação reprodutiva de 2002 (321 ovos).

Partindo do pressuposto de que não existem grandes problemas na alimentação dos animais em cativeiro, e do adequado estado de sanidade dos plantéis observados, esforços redobrados devem ser alocados, visando através da pesquisa aprimorar um sistema de acasalamento que aumente a fertilidade dos ovos. Este sistema necessariamente deve privilegiar o comportamento do animal. 


\subsection{Organização seqüencial dos comportamentos de perdizes}

Os resultados obtidos mostraram uma organização pouco informativa ou até "pobre", ao identificar um número pequeno de associações com árvores esgalhadas a partir de um único ato, não mostrando ramificações e assim falhando em identificar grupos de atividades associadas, à exceção dos ligados as atividades corporais.

Chama a atenção o fato do deslocamento sempre surgir no final ou no início de um surto comportamental, à exceção do parado que pode ocupar esta função para a arrumação. O deslocamento poderia estar associado a um papel de "adaptação postural", estabelecendo ao início e ao final de um surto comportamental uma posição de equilíbrio para a perdiz. Outra explicação é de que esta organização esteja refletindo comportamentos anormais associados ao deslocamento e a árvore seria típica de um animal hiperativo.

A simplicidade das árvores e a questão da posição do deslocamento podem ainda estar associado à própria questão de cativeiro, ao impossibilitar a manifestação de comportamentos ou rotinas (caminhos) em probabilidades suficientes para sua deteç̧ão.

O parado como mencionado, pode funcionar como entrada e saída para a arrumação, esta por sua vez está associada ao coçar para as fêmeas. Isto leva a identificar o grupo de limpeza corporal com estas características de organização diferenciadas dos demais atos comportamentais. As diferenciações observadas entre machos e fêmeas, mostram que, para estas existe uma estereotipia no sentido de uma organização mais rígida, o que segundo CROMBERG (1995) estaria associada aos comportamentos e funções reprodutivas. 


\section{CONCLUSÃO}

O presente trabalho determinou alguns padrões comportamentais de perdizes (Rhynchotus rufescens), nas condições propostas, apesar de surgirem dúvidas quanto ao estado reprodutivo (se estavam receptivos ou não) dos animais.

Os ritmos associados às atividades e sua distribuição temporal foram quantificados e avaliados. Mostrou-se ainda como a organização estrutural dos comportamentos ocorre.

Questões mais complexas como a distribuição espacial, o uso do espaço físico e social, com suas interações agonísticas e de dominância foram abordadas, e indicaram problemas de bem estar, provavelmente comprometendo a eficiência reprodutiva destes animais no cativeiro.

Assim, dúvidas referentes à adequação do sistema de acasalamento (29 para $1 \delta^{7}$ ) atualmente utilizado na FZEA/USP surgem, ao mesmo tempo em que é necessário separar estes fatores de um possível efeito ligado ao espaço disponível para as aves.

Trabalhos futuros devem estar atentos a estas questões. A investigação de um sistema de acasalamento eficaz é considerada fundamental para obter-se sucesso na criação desta espécie, e então se partir para sua seleção, contudo lembrando de estabelecer limites para esta, baseados em índices comportamentais da espécie, a fim de não incorrer-se nos erros que agora são nítidos com relação às aves especializadas para corte e postura. 
A criatividade na melhoria das instalações testadas por criadores, influindo assim no sistema de acasalamento dos animais, é um exemplo de como o desenho experimental pode ser delineado, uma vez que o método utilizado por MAGNANI ${ }^{2}$ (comunicação pessoal) que reproduz macucos (outra espécie de tinamídeo) muito bem, quando alocados em casais, com o mesmo não ocorrendo em grandes grupos. Ou então adotar a estratégia utilizada por AZEREDO (comunicação pessoal de MAGNANI), que reproduz bem os macucos mesmo em grupo, porém no recinto dos animais existem várias divisões, como se fossem labirintos, que são utilizados pelos animais em fuga quando agredidos por outros. O que pode ser considerado como uma solução interessante, por imitar o habitat natural destas aves.

\section{REFERÊNCIAS BIBLIOGRÁFICAS}

ALTMANN, J. Observational study of behaviour: sampling methods. Behaviour, v. 49, p. 227-267, 1974.

ANDREW, R. J. The aggressive and courtship behaviour of certain Emberizines. Behaviour, v. 10, p. 255-308, 1956a. . Normal and irrelevant toilet behaviour in Emberiza. The British Journal of Animal Behaviour, v. 4, p. 85-91, 1956b.

ASAHIDA, Y.; MINURA, K. Eating behaviour of chicks to 4 weeks of age. J. Fac. Fish. Anim. Husb., Hiroshima Univ., v. 11, p. 15-22, 1972. 
ASPEY, W. P. Wolf spider sociobiology: I. Agonistic display and dominancesubordinance relations in adult male Schizocosa crassipes. Behaviour, v. 62, p. 103-141, 1977.

BARTLETT, A. D. Notes on the breeding of several species of birds in the society's gardens during the year 1867. Proceedings of the Zoological Society of London, ano 1868, p. 114-116, 1868.

BALLARD, P. D.; BIELLIER, H. V. Effect of photoperiods on feed intake rhythms of domestic fowl. Int. J. Biometereol., v. 19, p. 125-128, 1975.

BESSEI, W. The behaviour of broilers under intensive management conditions. Arch. Gefluegelkd., v. 56, n. 1, p. 1-7, 1992.

BEIGUELMAN, B. Curso prático de bioestatística. 4. ed. Ribeirão Preto: Revista Brasileira de Genética. 1996.

BHATTI, B. M.; MORRIS, T. R. The effect of ahemeral light and dark cicles on patterns of food intake by the laying hen. Br. Poult. Sci., v. 19, p. 125128, 1978.

BLAAUW, F. E. Notes sur la reproduction du tinamou roux in captivité en Hollande. Bulletin de la Société Nationale d'Acclimation de France, v. 43, p. 513-516, 1896.

BOKERMANN, W.C.A. Observações sobre a biologia do macuco (Tinamus solitarius). 1991. 232 p. Tese (Doutorado em Ciências) - Instituto de Biociências, Universidade de São Paulo, São Paulo.

BRETT, L. P. \& LEVINE, S. Schedule-induced polydpsia suppresses pituitary-adrenal activity in rats. J. Comp. Physiol. Psychol., v. 93, p. 946956, 1979. 
BUDIANSKI, S. The Convenant of the Wild: Why Animal Chose Domestication. Willain Morrow, New York, 1992.

BUMP, G.; BUMP, J. W. A study of the Spotted Tinamous and the Pale Spotted Tinamous of Argentina. Spec. Scient. Rep. U. S. Fish WildI. Serv., v. 120 , p. 1-160, 1969.

BÜNNING, E. The Physiological Clock. Berlin: Spring Verlag, 1964.

BURGER, M. I Ciclo reprodutivo de fêmeas de uma população de Nothura maculosa TEMMINCK, 1815 (Aves, Tinamidae) no Rio Grande do Sul. Ilheringia, v. 71, p. 161-174, 1991.

CAIN, J. R.; WILSON, W. O. The influences of specific environmental parameters on the circadian rhythms of chickens. Poult, Sci., v. 53, p. 14381447, 1974.

CARNIO, A. Análise de algumas características produtivas e reprodutivas da Perdiz - Rhynchotus rufescens. Jaboticabal, 1993. 47 p. Trabalho apresentado à Faculdade de Ciências Agrárias e Veterinárias, Universidade Estadual Paulista, Jaboticabal.

CARNIO, A.; MORO, M. E. G.; GIANNONI, M. L. Estudos para a criação e reprodução em cativeiro da ave silvestre, Rhynchotus rufescens (TINAMIFORMES), com potencial para a exploração zootécnica. Ars Veterinária, v. 15, p. 140-143, 1999.

CARRANZA, J. Introducción a la ciencia del comportamiento. Cáceres: Universidade de Extremadura, Servicio de Publicaciones, 1994. 
CHATFIELD, C.; LEMON, R. E. Analysing sequences of behaviour events. J. Theoret. Biol., v. 29, p. 427-455, 1970.

CHANNING, J. E.; HUGHES, B. O.; WALKER, A. W. Spatial distribution and behaviour of laying housed in an alternative system. Appl. Anim. Behav. Sci., v. 72, p. 335-345, 2001.

CRAVINO, J. L. La Martineta, Rhynchotus rufescens, cria y explotacion. Montevideo: Agropecuaria Hemisferio Sur, [199-]. 89 p. s. d.

CROMBERG, V. U., A organização do comportamento de auto-limpeza corporal de machos e fêmeas de Musca domestica. 1995. 76 p. Tese (Doutorado) - Instituto de Psicologia, Universidade de São Paulo, São Paulo.

CROMBERG, V. U.; MORO, M. E. G. \& TOLEDO, L. M. Seletividade no forrageamento de perdizes (Rhynchotus rufescens), em três frações granulométricas de uma relação farelada. In: XIV Encontro Anual de Etologia, 14, 1996, Uberlândia. Anais de Etologia, Uberlândia: UFU, 1996, p. 339.

DANTZER, R.; MORMEDE, P. De-arousal properties of stereotyped behaviour: evidence from pituitary-adrenal correlates in pigs. Appl. Anim. Ethol., v. 10, p. 233-244, 1983.

DANTZER, R. et al. Schedule-induced polydpsia experience decreases plasma corticosterone levels but increases plasma prolactin levels. Physiol. Behav., v. 43, p. 275-279, 1988.

DAVIS, D. E. Breeding biology of birds. In: WOLFSON, S. Avian Biology, Urbana: Univ. of Illinois Press, 1955. p. 264-308. 
DAWKINS, M. S. Animal Suffering. New York: The Science of Animal Welfare, Chapman and Hall, 1980.

DAWKINS, M. S. Priorites in the cage size and flooring preferences of domestic hens. Br. Poult. Sci., v. 22, p. 255-263, 1981.

DEL HOYO, J.; ELLIOT, A. S.; SARGATAL, J. Handbook of the birds of the world. Barcelona: Lynx Edicions, 1992. v. 1.

DETHIER, V. G. \& STELLAR, E. Comportamento Animal, 151p., Editora Edgar Blücher, São Paulo,1988.

DINGLE, J. G. Feeding activity of caged layers. Poult. Sci., v. 50, p. 15201521, 1971.

DOYEN, J.; ZAYAN, R. Measures of space in pairs of hens in battery cages. Behav. Process., v. 9, p.157-190, 1984.

DUNCAN, I. J. H. \& WOOD-GUSH, D. G. M., Thwarting of feeding behaviour in the domestic fowl. Anim. Behav., v. 20, p. 444-451, 1972.

DUNCAN, I. J. H.; HUGHES, B. O. Feeding activity and egg formation in hens lit continuously. Br. Poult. Sci., v. 16, p. 145-155, 1975.

EMLEN, S. T.; ORING, L. W. Ecology, sexual selection and the evolution of mating systems. Science, v. 197, p. 215-223, 1977.

EVANS, H. L. Rat's acitivity: influence of light-dark circle, food presentation and deprivation. Physiol. Behav., v. 20, p. 455-459, 1971.

FAABORG, J.; PATERSON, C. B. The characteristics ans occurrence of cooperative poliandry. Ibis, v. 4, n. 123, p. 477-484, 1981. 
FAURE, J. M. Choice tests for space in groups of laying hens. Appl. Anim. Behav. Sci., v. 39, p. 89-94, 1994.

FERNANDES, J. A organização dos cmportamentos de limpeza corporal de musca domestica: um estudo de causação. Dissertação (Mestrado) Instituto de Psicologia, Universidade de São Paulo, 1984.

FOWLER, M. E. Zoo \& wild animal medicine. Colorado: W. B. Saunders, p.277-292, 1986.

FRANÇOIS, N.; MILLS, A. D.; FAURE, J. M. Place preferences of Japanese quail given a permanent choice between a social or a non-social but enriched situation. Behavioural Processes, v. 43, p. 163-170, 1998.

FRAPS, R. M. Egg production and fertility in poultry. In HAMMOND, J. Progress in the physiology of farm animals. London: Butterworths, 1955. v. 2 , p. 661-740.

FRASER, A.F.; BROOM, D.M. Farm animal behaviour and welfare. $4^{a}$ edition, London, Baillière Tindall, 1997.

FRASER, F. J. et al., Farm animals and their welfare in 2000. In: The Estate of Animal, 2001. Disponível em:

http://www.hsus.org/marketplace/hum.../book.stateofanimals.htm

FUJITA, H. Quantitative studies on the variations in feeding activity of chickens: II, Effect of the physycal form of the feed on the feeding activity of laying hens. Jpn. Poult. Sci., v. 10, p. 47-54, 1973a.

The effect of length of daily periods on diurnal feeding activity of laying hens. Jpn. Poult. Sci., v. 10, p. 123-127, 1973 b. 
GALLARDO, J. M. Observaciones sobre el comportamiento social y reprodutivo de Eudromia elegans (Aves: Tinamiformes). Revista del Museo Argentino de Ciencias Naturales, n. 16, p. 163-166, 1984.

GILBERT, A. B.; WOOD-GUSH, D. G. M. Ovulatory and ovipository cycles. In: BELL, D. J.; FREEMAN, B. M. Physiology and biochemistry of the domestic fowl. London: Academic Press, 1971. v. 2, p. 1353-1378.

GROSS, W. B. \& SIEGEL, H. S. Evaluation of the heterophil/lymphocyte ratio as a mensure of stress in chickens. Avian Dis., v. 27, p. 972-979, 1983.

GYSELS, H. Some ideas about the phylogenetic relationships of the Tinamiformes based on protein characters. Acta Zool. Pathol. Antverpiensia, v. 50, n. 11, p. 3-13, 1970.

HALE, E. B. Domestication and the evolution of behavior. In: HAFEZ, E. S. E. The Behaviour of Domestic Animals. 2. ed. London: Baliere, Tindall \& Cassel, 1969. p. $22-42$.

HAMILTON, W. D. Geometry of the selfisch herd. J. Theor. Biol., v. 31, p. 295-311, 1971.

HEDIGER, H. Studies of the Psychology and Behaviour of Captive Animals. Dover, New York, 1955.

HILL, K. J. ; STRACHAN, P. J. Recent advances in digestive physiology of the fowl. Symp. Zool. Soc. London, v. 35, p. 1-12, 1975.

HUCK, U. W.; PRICE, E. O. Differential effects of environmental enrichment on the open-field behavior of wild and domestic. J. Comp. Physiol. Psychol., v. 89, p. 892-898, 1975. 
HUDSON, M. W. Las perdices de la Argentina. Hornero, v. 4, n. 2, p. 174$183,1928$.

HUGHES, B. O. Allelomimetic feeding in the domestic fowl. Br. Poult. Sci. , v. 12 , p. 359-366, 1971.

A circadian rhytm of calcium intake in the domestic fowl. $\mathrm{Br}$.

Poult. Sci., v. 13, p. 485-493, 1972.

The concept of optimum stocking density and its selection for egg production. In: FREEMAN, B. M.; BOORMAN, K. N. Economic factors affecting egg production. Edinburgh: British Poultry Science, 1975. p. 271298.

HUGHES, B. O.; BLACK, A. J. Battery cage shape: its effect on diurnal feeding pattern, egg shell cracking and feather pecking. Br. Poult. Sci., v. 17, p. 327-336, 1976.

Diurnal patterns of feeding and activity in laying hens in relation to dietary restriction and cage shape. Br. Poult. Sci., v. 18, p. 353-360, 1977.

IRVING, L. et al. Winter feeding program of Alaska willow ptarmigan shown by crop contents. Condor, v. 69, p. 69-77, 1967.

JENSEN, P. Diurnal rhythm of bar-biting in relation to other behaviour in pregnant sows. Appl. Anim. Behav. Sci., v. 21, p. 337-346, 1988.

JONES, R. B. The tonic immobility reaction of the domestic fowl: a review. World's Poultry Science Journal, v. 42, n. 1, p. 82-96, 1986. 
KEELING, L. J. Inter-bird distances and behavioural priorities in laying hens: the effect of spatial restriction. Appl. Anim. Behav. Sci., v. 39, p. 131-140, 1994.

Spacing behaviour and na ethological approach to assessing optimum space allocations for groups of laying hens. Appl. Anim. Behav. Sci., v. 44, p. 177-181, 1995.

KEELING, L. J. \& DUNCAN, I. J. H. Social spacing in domestic fowl under semi-natural conditions: the effect os behavioural activity and activity transitions. Appl. Anim. Behav. Sci., v. 32, p. 205-217, 1991.

Inter-individual distances and orientation in laying hens housed in groups of three in two different-sized enclosures. Appl. Anim. Behav. Sci., v. 24, p. 325-342, 1989.

KOSTAL, L.; SAVORY, C. J.; HUGHES, B. O. Diurnal and individual variation in behaviour of restricted-fed broiler breeders. Appl. Anim. Behav. Sci., v. 32 ,

p. 361-374, 1992.

LAGADICE, H.; FAURE, J. M. Preferences of domestic hens for cage size and floor type as measured by operant conditioning. Appl. Anim. Ethol., v. 19, p. 147-155, 1987.

LEGENDRE, P. \& LEGENDRE, L. Numerical Ecology. $2^{\text {a }}$ edição, Elsevier Science B. V., Amsterdan, 2000.

LEHNER, P. N. Sampling methods in behaviou research. Poultry Science, v. 71, p. 643-649, 1992. 
LIEBERMANN, J. Monografia de las tinamiformes argentinas y el problema de su domestication. Buenos Aires: Editora Talleres Gráficos, 1936.

MANKOVICH, N. J. \& BANKS, E. M. An analysis of social orientation and the use of space in a flock of domestic fowl. Appl. Anim. Ethol., v. 9, p. 177193, 1982.

MARTIN, R. D. Breeding Endangered Species in Captivity. New York: Academic Press, 1975.

MARTIN, P.; BATESON, P. Measuring behaviour. Cambridge: Cambridge University Press, 1986.

MASIC, B. et al. A comparison of the feeding behaviour of young broiler and layer males. Br. Poult. Sci., v. 15, p. 499-505, 1974.

MASON, G. J. Individual variation in the stereotypies of caged mink. Appl. Anim. Behav. Sci., v. 28, p. 300-301, 1990.

MAULDIN, J. M. Applications of behaviour to poultry management. Poultry Science, v. 71, p. 634-642, 1991.

McBRIDE, G. Theories of animal spacing: the role of flight, fight and social distance. In: The Social Use of Space in Animals and Man. Plenum Press, New York, 1971.

McCORT, W. D. \& GRAVES, H. B. Social dominance relationships and spacing behaviour of swine. Behav. Process., v. 7, p. 169-178, 1982.

McDOWELL, S. The bony palate of birds: the palaeognathae. Auk, v. 65, n. 30, p. 520-549, 1948. 
MENEGHETI, J. O. Observações preliminares sobre o acasalamento e recrutamento em Nothura maculosa (TEMMINCK, 1815) (AVES, Tinamidae) no Rio Grande do Sul, Brasil. Ilheringia, v. 59, p. 65-75, 1981.

MENEGHETI, J. O.; MARQUES, M. I. B. Reprodução e mortalidade da perdiz. Natureza em Revista, v. 8, p. 26-31, 1981.

MENEGHETI, J. O.; FROZI, M.; BURGER, M. I. The growth curve of the Red-winged Tinamou (Rhynchotus rufescens, TEMMINCK, 1815) (AVES, TINAMIDAE). Iheringia Ser. Misc., Porto Alegre, v. 1, p. 47-54, 1985.

MILLER, R. S.; BOTKIN Endangered species: models and predictions. Am. Sci., v. 62, p. 172-181, 1974.

MISTLBERGER, R. \& RUSAK, B. Palatable daily meals antrain anticipatory activity rhythms in free-feeding rats: dependence on meal size and nutrient content. Physiol. Behav., v. 41, p. 219-226, 1987.

MORO, M. E. G. Análise citogenética e alguns aspectos produtivos da espécie Rhynchotus rufescens - Perdiz (Aves: Tinamidae). 1991. 97 p. Dissertação (Mestrado em Zootecnia) - Faculdade de Ciências Agrárias e Veterinárias, Universidade Estadual Paulista, Jaboticabal.

- Desempenho e características de carcaça de perdizes (Rhynchotus rufescens) criadas com diferentes programas de alimentação na fase de crescimento. 1996. 75 p. Tese (Doutorado em Zootecnia) - Faculdade de Ciências Agrárias e Veterinárias, Universidade Estadual Paulista, Jaboticabal.

MONGIN, P. \& SAUVER, B. Voluntary food and calcium intake by the laying hen. Br. Poult. Sci., v. 19, p. 747-753, 1974. 
MONTES, L. M. Las Perdices. Buenos Aires, Editorial Albatros, 1977. 86 p.

MORRIS, B. A.; TAYLOR, T. G. The daily food consumption of laying hens in relation to egg formation. Br. Poult. Sci., v. 8, p. 251-257, 1967.

MURPHY, L. B.; PRESTON, A. P. Time budgets in meat chickens grown commercially. Br. Poult. Sci., v. 29, p. 571-580, 1988.

MYERS, J. P. Spacing behaviour in non breeding shorebirds. In: BURGER, J. L. \& OLLA, B. L., Shorebirds: Migration and Foraging Behaviour, p. 271-321, 1984.

NELSON, K. Does the holistic study of behaviour have a future? In: BATESON, P. G.; KOPFLER Perpectives in ethology New York: Plenum Press, 1973.

NEWBERRY, R. C. The space-time continumm, and its relevance to farm animals. Etologia, v. 3, p. 219-234, 1993.

NEWBERRY, R. C.; HUNT, J. R.;GARDINER, E. E. Influence of light intensity on behaviour and performance of broiler chickens. Poult. Sci., v. 67 , p. $1020-1025,1988$.

NICOL, C. Non-exclusive spatial preference in the laying hen. Appl. An. Behav. Sci., v. 15, p. 337-350, 1986.

NYS, Y. et al. Food, calcium and water intakes by hens lit constinuously from hatching. Br. Poult. Sci., v. 17, p. 351-358, 1976.

ODBERG, F. O. Abnormal behaviours: stereotypies. In: Proocedings from the 1st World Congress on Ethology Applied to Zootechnics, Madrid, p. 475-480, 1978. 
ORIANS, G. H. On the evolution of mating sistems in birds and mamals. Am. Nat., v. 103, n. 934, p. 589-603, 1969.

ORING, L. W. Avian mating systems. In: Avian Biology, FARNER, D. S. ; KING, J. R. \& PARKES, K. C., p. 1-92, volume 6, Academic, New York, 1982.

OSHIMA, S; SHIMADA, K.; TONOUE, T. Radio telemetric observations of the diurnal changes in respiration rate, heart rate and intestinal motility of domestic fowl. Poult. Sci., v. 53, p. 503-507, 1974.

PACHECO, S. et al. Efeito do manejo do cerrado de alguns Tinamidae em Três Marias, Estado de Minas Gerais. Rev. Brasil. Biol., v. 54, n. 3, p. 435441, 1994.

PALYA, W. L. \& ZACNY, J. P. Stereotyped adjunctive pecking by caged pigeons. Anim. Learn. Behav., v. 8, p. 293-303, 1980.

PARANHOS DA COSTA, M. J. R.; CROMBERG, V. U. Ambiência na produção de bovinos de corte a pasto. ANUALPEC, p. 68-73, 2001.

PARKERS, K. C.; CLARK, G. A. An additional character linking Ratites and Tinamous, and an interpretation of their monophyly. The condor, v. 68, n. 13, p. 459-471, 1966.

PIANKA, E. R. Evolutionary ecology. 356 p, New York: Harper \& Row, 1974.

POUGH, F. H.; HEISER, J. B. \& McFARLAND, W. N. A vida dos Vertebrados, 798 p., $2^{a}$ edição, Ateneu Editora, São Paulo, 1999. 
PRICE, E. O. Behavioural aspects of Animal Domestication. The Quarterly Review of Biology, v. 59, p. 1-32, 1984.

RATNER, S. C.; BOICE, R. Effects of domestication on behaviour, In: The Behaviour of Domestic Animals. 3. ed. Baltimore: Williams and Wilkins, 1975.

ROCHE, M.; DECERPRIT, J. Contrôles hormonal et nerveux de la motricité du tratus digestif de la poule. Ann. Rech. Vet., v. 8, p. 25-40, 1977.

RUSHEN, J. Stereotyped behaviour, adjunctive drinking and the feeding periods of tethered sows. Anim. Behav., v. 32, p. 1059-1067, 1985.

SANTOS, E. Da ema ao beija-flor. Belo Horizonte: Itatiaia, 1979. p. 21-35.

SATO, O estudo da organização do comportamento através da teoria dos grafos. Biotemas, v. 4, p. 95-110, 1991.

SAVORY, C. J. A growth study of broiler and layer chicks reared in singlestrain and mixed-strain groups. Br. Poult. Sci., v. 17, p. 557-560, 1975.

Effects of different lighting regimes on diurnal feeding patterns of the domestic fowl. Br. Poult. Sci., v. 17, p. 341-350, 1976a.

. Broiler growth and feeding behaviour in three different lighting regimes. Br. Poult. Sci., v. 17, p. 557-560, 1976 b.

, Effects of egg production on the pattern of food intake of broiler hens kept in continuous light. Br. Poult. Sci., v. 18, p. 331-337, 1977. Meal occurrence in Japanese quail in relation to particle size and nutrient density. Anim. Behav., in press, 1979. 
Diurnal feeding patterns in domestic fowls: a review. Appl. Anim. Ethol., v. 6, p. 71-82, 1980.

SAVORY, C. J.; WOOD-GUSH, D. G. M.; DUNCAN, I. J. H. Feeding behaviour in a population of domestic fowls in the wild. Appl. Anim. Ethol., v. 4 , p. 13-27, 1978.

SAVORY, C. J; SEAWRIGHT, E. \& WATSON, A. Stereotyped behaviour in broiler breeders in relation to husbandry and opioid receptor blockade. Appl. Anim. Behav. Sci., v. 32, p. 349-360, 1992.

SCHNEIRLA, T. C. An evolutionary and developmental theory of biphasic processes underlyng approach and with drawal. In: JONES, M. R., Nebraska Symposium on Motivation, 1959.

SECRETARIA DO MEIO AMBIENTE. Fauna ameaçada no Estado de São Paulo. São Paulo: SMA/CED, 1998. 56 p.

SERIÉ, P.; SMITH, C. H. Notas sobre aves de Santa Elena (Entre Rios), Hornero, v. 3, n. 1, p. 37-55, 1923.

SICK, H. Ornitologia Brasileira, uma introdução. Editora Nova Fronteira, Rio de Janeiro,792 p., 1997.

SLATER, P. J. B.; OLLASSON, J. C. The temporal patterning of behaviour in isolated male zebra finches: transition analysis. Behaviour, v. 42, p. 248269, 1972.

SLATER, P. J. B. Describing sequences of behaviour, In: BATESON, P. G.; KLOPFER, R. Perspectives in etology. New York: Plenum Press, 1973. 
STOKOLS, D. On the distinction between density and crowding. Psychol. Rev., v. 79, p. 275-277, 1972.

STRICKLIN, W. R. Spatial and temporal dimensions of bovine behaviour and social organization. Unplubishe Ph. D. Thesis, Pennsylvania State University, 1975.

THOLON, P. Avaliação da adaptação de perdizes (Rhynchotus rufescens) ao cativeiro. 2002. 54 p. Dissertação (Mestrado) - Faculdade de Ciências Agrárias e Veterinárias, Universidade Estadual Paulista, Jaboticabal.

THORPE, W. H. Learning and Instinct in Animals Metheum, London, 1956.

TWIEST, G. \& SMITH, C. J. Circadian rhythm in blood glucose level of chickens. Comp. Biochem. Physiol., v. 32, p. 371-375, 1970.

ZAYAN, R. Social space for domestic animals. Amsterdam: Martinus Nijhoff, 1985. 291 p.

ZAYAN, R. \& DOYEN, J. Spacing behaviour of laying hens kept at different densities in battery cages. In: ZAYAN, R. Social Space for Domestic Animals. CEC Seminar, Brusseis/Amsterdan, Martinus Nijhoff, Dordrecht, p. 37-71, 1985.

VAN DER HEIJEN, P. G. M.; VRIES, H. de; VAN HOOF, J. A. R. A M. Correspondence analysis of transition matrices, with special to missing entries and asymmetry. Animal Behaviour, v. 40, p. 49-64, 1990.

VAN HEMEL, S. B.; MYER, J. S. Feeding patterns and response to caloric dilution in the Japanese quail. Physiol. Behav., v. 4, p. 339-344, 1969. 
VAN HOOF, J. A. R. A. M. Categories and sequences of behaviour: methods of description and analysis. In: SCHERER, K. R. \& EKMAN, P., Handbook of methods in nonverbal behaviour research. Cambridge Univ. Press, 1982.

WALLACE, G.J.; MAHAN, H. D. Introduction to ornithology. 3. ed. New York: Macmillan Publishing, 1975.

WEEKS, C. A. et al. Comparison of the behaviour of broiler chickens in indoor and free-range environments. Anim. Welf., v. 3, p. 179-192, 1994.

WEEKS, C. A. et al. The behaviour of broiler chickens and its modification by lameness. Appl. Anim. Behav. Sci., v. 67, p. 111-125, 2000.

WEEKS, S. E. The behaviour of the red-winged tinamou, Rhynchotus rufescens. Zoologica. S.I.: Springs, 1973. p. 13-40.

WIEPKMA, P. R. et al., Behaviour and abomasal damage in individual veal calves. Appl. Anim. Behav. Sci., v. 18, p. 257-268, 1987.

WILSON, W. O.; WOODART, A. E. ; ABAPLANALP, H. Exogenous regulation of oviposition in chickens. Poult. Sci., v. 43, p. 1187-1192, 1964.

WOOD-GUSH, D. G. M. Time-lapds photography: a technique for studying diurnal rythms. Physiol. Zool., v. 32, p. 272-283, 1959.

. Strain differences in response to sub-optimal stimuli in the fowl. Anim. Behav., v. 20, p. 72-76, 1972.

WOOD-GUSH, D. G. M.; HORNE, A. R. The effect of egg formation and laying on the food and water intake of Brown Leghorn hens. Br. Poult. Sci., v. 11, p. $459-466,1970$. 


\section{ANEXO A}

\section{Metodologia das Análises Utilizadas}

\section{Experimental vs. Observacional}

Os dados de pesquisas biológicas, de maneira geral, são produto de dois métodos: o observacional, também chamado por alguns de descritivo e o experimental. Complementarmente, fazendo-se distinção entre as observações de campo ou naturalísticas e os estudos de laboratório, podese categorizar a pesquisa (ecológica ou comportamental) dentro de um contínuo de estudos que vão desde os descritivos da natureza à manipulação laboratorial experimental.

O método experimental pressupõe um grupo ou apenas um indivíduo, sujeito à manipulação experimental, isto é, pode-se dividir a comunidade em partes passíveis de replicação dos vários tratamentos e contra-testes. Desta forma, qualquer diferença detectada numa resposta medida pode ser atribuída aos tratamentos experimentais. Baseando-se numa aproximação observacional, faz-se medições dos sujeitos sobre uma vasta gama de condições impostas pela natureza em vez do experimentador. Com isto, têm-se duas alternativas: (a) estudar diferentes amostras obtidas ao mesmo tempo, mas sob condições diferentes ou (b) estudar amostras obtidas no mesmo lugar mas em diferentes tempos (LUDWING, 1988).

Abrindo-se mão de qualquer manipulação de variáveis, dentro deste contexto acima definido, adentra-se na aproximação observacional que é indutiva, não experimental e multivariada. Procurando-se elucidar e descrever os padrões observados, em vez de testar uma hipótese "a priori", através do que pode-se denominar de métodos de detecção de padrões (Pattern detection methods - GREEN, 1980). 
Em alguns casos a detecção de padrões específicos através das amostragens pode levar a formação de hipóteses casuais sobre as estruturas subjacentes dos grupos de animais observados, que podem então ser testadas em trabalhos posteriores, inclusive baseados em uma abordagem experimental.

Apesar de alguns autores acharem que estudos descritivos são mais válidos quando conduzidos em condições naturais (LEHNER, 1992), em algumas espécies como no caso da perdiz, onde as observações a campo se tornam difíceis de serem realizadas, o pesquisador deve considerar o quanto do repertório do animal é retido ou pode ser apreendido, através de observações discretas em condições artificiais. No presente estudo, utilizouse uma abordagem de observação naturalística, onde linhas de pesquisa sobre a domesticação de animais com potencial zootécnico que se iniciem pela investigação dos comportamentos típicos da espécie considerados ecologicamente relevantes, estão dentro de uma tendência que ganha cada vez mais terreno dentro das ciências comportamentais (JOHNSTON, 1981; ADES, 1986; CROMBERG, 1991), onde se procura avaliar o efeito das condições de criação dos animais; com esta variável passando a compor o "habitat" dos sujeitos em foco.

\section{Séries de Dados}

O uso e a análise de séries de dados é cada vez mais popular dentro dos estudos que envolvem atividades dos animais, quer etológicos ou zootécnicos, principalmente à medida que equipamentos automáticos de medições se tornam mais disponíveis. Estes estudos dizem respeito não só a variáveis continuas ou discretas amostradas no tempo mas também espacialmente, ao longo de transectos.

Uma série de dados é uma seqüência de observações que são ordenadas sobre um eixo espacial ou temporal. Um processo é um 
fenômeno (resposta variável), ou um tipo de fenômeno, que é organizado sobre um eixo independente. Processos estocásticos, geralmente exibem três tipos de componentes: determinantes, sistemáticos e aleatórios. Diversos métodos de análises numéricas de séries de dados foram elaborados para caracterizar os componentes determinantes e sistemáticos presentes na série, dado o ambiente probabilístico resultante da presença de componentes aleatórios.

O eixo mais natural ao longo do qual um processo pode ser estudado é o tempo, porque o fenômeno temporal desenvolve-se numa forma irreversível e independente de qualquer decisão feita pelo observador. Geralmente interessa-se por mudanças periódicas, devendo-se isto em parte pelo fato da maioria dos fenômenos ecológicos serem largamente determinados por ritmos geofísicos; também existindo aqueles ritmos que são endógenos ao organismo ou ao ecossistema.

As análises de série de dados fornecem informações únicas sobre os fenômenos ecológicos ou biológicos. A qualidade dos resultados depende em larga extensão dos métodos de coleta de dados. A maioria dos métodos numéricos requer que as séries obtidas sejam feitas sobre um grande número de observações ( $n>100$ ou mesmo $n>1000)$.

O ponto fundamental a ser considerado na análise periódica é a janela observacional. A amplitude da janela é determinada pelo número de observações na série de dados (n) e o intervalo (tempo ou distância) entre observações sucessivas. Este intervalo é chamado de lag (defasagem), $\Delta$; para o tempo existente, assume-se que é uniforme para toda a série de dados. Estas duas características fixam o tempo ou o domínio de espaço que pode ser observado quando analisa-se uma série de dados. Para dados temporais refere-se ao período $(T)$ ou a freqüência $(f=1 / T)$ enquanto que para o dado espacial os conceitos correspondentes são: comprimento de onda $(\lambda)$ e número de ondas $(1 / \lambda)$. $O$ comprimento da série $(\Delta n)$ para o dado 
temporal denomina-se período fundamental $\left(T_{0}=\Delta n\right)$ ou freqüência fundamental $(f o=1 / T o=1 / \Delta n)$ e para o dado espacial, comprimento de onda fundamental $(\lambda 0=\Delta n)$ ou número de onda fundamental $(1 / \lambda 0=1 / \Delta n)$. Períodos harmônicos e comprimentos de ondas são frações integrais do período fundamental e comprimento de ondas respectivamente $(\mathrm{Ti}=\mathrm{To} / \mathrm{i}$ e $\lambda \mathrm{i}=\lambda \mathrm{o} / \mathrm{i}$, onde $i=1,2, \ldots n)$, enquanto que as freqüências harmônicas e os números de ondas são múltiplos integrais da freqüência fundamental e do numero de ondas, respectivamente ( $\mathrm{fi}=\mathrm{ifo}$ e $1 / \lambda \mathrm{i}=\mathrm{i} / \lambda \mathrm{o}$ ). Considerando-se os limites reais da janela observacional, o período mais longo ou o comprimento de onda que pode ser estatisticamente investigado é igual à metade do comprimento da série $(\Delta \mathrm{n} / 2)$. Por exemplo, num estudo de ritmo circadiano (24 horas), as séries precisam ter um mínimo comprimento de 2 dias (melhor seria 4 dias ou mais). Similarmente, em uma área onde as estruturas espaciais são da ordem de $2 \mathrm{~km}$, um transecto precisa cobrir pelo menos $4 \mathrm{~km}$ (melhor $8 \mathrm{~km}$ ou mais). Semelhantemente, o menor período ou comprimento de onda que

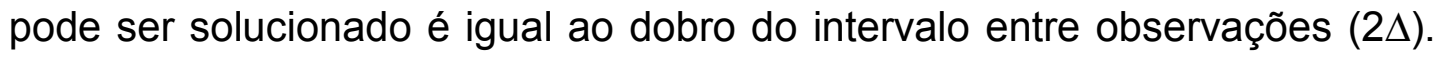
Em termos de freqüência, a maior que pode ser solucionada, $1 / 2 \Delta$, chamada de freqüência de Nyquist. Por exemplo, se o interesse é sobre a variação hora a hora, a observação precisa ser feita pelo menos a cada $30 \mathrm{~min}$.

As séries podem ser analisadas em termos de mudanças determinísticas (tendências); sistematização (periodicidade) e flutuações ao acaso (ruído). Identificar períodos característicos dos comportamentos observados foi uma das intenções deste trabalho. Séries comportamentais, como tantas outras podem exibir flutuações irregulares ou imprevisíveis, chamadas de ruídos, que são devidas muitas vezes a fatores perturbadores esporádicos ou não permanentes. Quanto maior o ruído mais difícil se torna a identificação da periodicidade quando analisamos uma série, sendo portanto às vezes necessário a identificação e eliminação destes ruídos.

Na análise espectral (de fácil computação), a variância das séries de dados é dividida entre freqüências (ou numero de ondas) na obtenção da 
estimativa do espectro da variância, isto é uma característica global da série. Este método exige contudo que a série seja estacionária, ou seja que a média, variância e outras propriedades estatísticas da distribuição seja constante sobre a série. Muitas vezes é necessário portanto estimar-se esta tendência (por exemplo, através de regressão linear) e eliminá-la (calcular a regressão residual).

A análise espectral decompõe a série original em funções senoidais e cosenoidais de diferentes freqüências, para determinar-se aquelas que parecem particularmente fortes ou importantes, tratando-se a série como uma regressão linear múltipla. Em outras palavras, existirá tantas ondas sinusoidais diferente, quantos forem os pontos de dados (observação) e devendo-se ser capaz de reproduzir a série destas funções; identificando a correlação das funções seno e coseno das diferentes freqüências com o dado observado. Se uma correlação forte é identificada, conclui-se que existe uma grande periodicidade desta respectiva freqüência (ou período) nos dados.

Valor de $\mathrm{Y}$ na análise espectral:

$\mathrm{Y}(\mathrm{x})=\mathrm{ao}+\sum_{k=1}^{n / 2}\left[a_{k} \cos \left(2 \pi f_{k} x\right)+b_{k} \sin \left(2 \pi f_{k} x\right)\right]$

Constante ao é a média da série

Ak e bk determinam a importância de em um dado período Tk no sinal resultante.

$\mathrm{fk}=1 / \mathrm{Tk}$ (freqüência)

O termo .... transforma a variável explicativa x numa variável cíclica.

A intensidade do periodograma a freqüência fk é obtida computandose a estimativa dos quadrados mínimos dos coeficientes ak e bk:

$\mathrm{I}(\mathrm{fk})=\mathrm{n}(\mathrm{ak} 2+\mathrm{bk} 2) / 2$ 
A intensidade do periodograma é definida apenas para as freqüências harmônicas $\mathrm{k} / \mathrm{n} \Delta$. Entretanto é possível transformar a intensidade do periodograma numa função continua sobre todas as freqüências do zero a de Nyquist. Isto define o espectro da série:

$\operatorname{Syy}(f)=n(a 2 f+b f 2) / 2 \quad 0 \leq f \leq f_{n / 2}$

O espectro é assim uma função contínua da freqüência, enquanto o periodograma é descontínuo.

\section{Análise de seqüências}

A organização do comportamento é investigada por dois caminhos: pela descrição dos padrões de encadeamento, com a detecção das leis desta associação ou pela análise dos princípios subjacentes dos fatores de interação internos e externos ao organismo com a organização e controle do comportamento (VAN HOOFF, 1982). Esta última etapa baseia-se e é direcionada pelo conhecimento descritivo obtido na primeira, e está relacionada com a função do comportamento.

Os métodos atualmente utilizados para se investigar o primeiro caminho seguem também duas direções: (a) aqueles que investigam as dependências seqüenciais do encadeamento comportamental e (b) aqueles que consideram a organização do sistema comportamental como um sistema de diferentes rotinas, cada rotina constituída por um conjunto de atos, coordenadas para executar uma certa função.

Uma seqüência pode ser vista como um processo estocástico. Os processos estocásticos mais comuns são as cadeias de Markov; nestas, a ocorrência de um ato depende de um ato anterior na seqüência e é justamente a natureza e o grau desta dependência que se quer revelar.

A análise seqüencial se inicia com a construção de uma matriz de transição dos atos (a duração das atividades não são consideradas), onde 
as linhas representam os atos precedentes $e$ as colunas os atos subseqüentes. Um dos pré-requisitos para a redução dos dados através de uma matriz de primeira ordem, independente de vantagens ou não deste procedimento, (VAN DER HEIJEN et al. 1990) é que o processo seja estacionário (i.e. que as probabilidades de transição não mudem com 0 tempo). Se o número de categorias não for muito grande, é possível visualizar-se alguns aspectos da organização seqüencial, a partir da construção de diagramas ("path diagrams" ou "Kinematic graphs"), obtidos diretamente dos dados de transição.

O tratamento dos dados a partir de matrizes de transição compreende sua transformação para uma matriz de probabilidades condicionais. Como as transições absolutas refletem a freqüência individual dos comportamentos mais do que a relação entre os comportamentos, pode-se expressar a similaridade $^{1}$ em termos de probabilidades condicionais (probabilidade de um comportamento dado à ocorrência de um determinado comportamento). A transição esperada entre dois atos é igual ao produto do total da respectiva linha e coluna da matriz de transição dividido pela soma total das transições entre todos os elementos. Esta fórmula torna-se inadequada quando existem caselas vazias na tabela (SLATER \& OLLASON, 1972; SLATER, 1973).

Existem diversos procedimentos (FERNANDES, 1984) para se determinar à diferença entre os valores observados e os esperados. $O$ critério de ANDREW, (1956 a, b), utilizado, envolve para cada casela o cálculo de um índice obtido pela subtração da freqüência esperada da freqüência observada, dividido pela raiz quadrada da freqüência esperada. Segundo ASPEY (1977), se este índice for maior ou igual a 2,58 a diferença entre $o$ valor observado e o valor esperado pode ser considerada significativa $(p<0,01)$. Após a análise estatística pode-se considerar apenas as transições estatisticamente significantes para análise. 
O conceito de associação refere-se à dependência seqüencial existente entre os atos da seqüência. Os atos podem ser independentes de outros que o precedem (dependência de ordem zero) ou podem apresentar dependência de ordem superior: dependente do ato imediatamente anterior (dependência de $1^{\text {a }}$ ordem) ou dos dois atos imediatamente anteriores (dependência de $2^{\mathrm{a}}$ ordem), etc. O modelo de Markov despreza a possível influência de interdependência sobre o comportamento de eventos temporais, como por exemplo, a duração do evento e o intervalo entre eles. As cadeias de Markov apenas descrevem um padrão de transição entre as categorias e não pressupõem nem implicam em mecanismos específicos subjacentes (NELSON, 1973). A sua utilidade básica seria a de fornecer uma abordagem inicial, uma sumarização da dinâmica do comportamento (CHATFIELD \& LEMON, 1970; FERNANDES, 1984).

A dependência seqüencial é detectada através de vários métodos de análise seqüencial (FERNANDES, 1984), entretanto, utiliza-se apenas de uma matriz de transição de $1^{\mathrm{a}}$ ordem como ponto de partida ao presente estudo; além de trazer simplificações, SATO (1991) e CROMBERG (1995), justificam seu uso: a) a matriz de transição de $1^{\text {a }}$ ordem é uma estrutura relativamente simples de analisar; b) existem vários modelos de análise para estas matrizes; c) o número de eventos na seqüência empírica é normalmente insuficiente para suportar análises estatísticas das ordens mais elevadas; d) na maioria das seqüências comportamentais, dependência de $1^{\text {a }}$ ordem constitui o aspecto mais importante e muitas vezes o único da seqüência; e) mesmo que a seqüência apresente dependência de ordem superior, é sempre útil analisar a matriz de transição de $1^{\mathrm{a}}$ ordem.

Uma fonte de métodos alternativos para a análise de seqüências é a teoria dos grafos, em especial os procedimentos de busca de árvores (SATO, 1991). A unidade básica de análise é a seqüência das categorias e procura-se seguir a recomendação de SLATER \& OLLASON (1972) e SLATER (1973), que consiste em que não se anotem repetições sucessivas 
de uma mesma atividade, na análise de seqüências, uma vez que isto pode gerar um volume grande de autotransições, que acabam encobrindo outras relações interessantes.

Estas técnicas partem de uma matriz de (dis) similaridades e geram representações visuais (um diagrama em forma de árvore), onde as relações de associação (quando um ato segue outro numa freqüência superior à esperada pelo acaso) e equivalência (quando um comportamento representa uma escolha alternativa num mesmo ponto do processo de decisão) estão naturalmente representadas (SATO, 1993). A visualização da árvore é representativa e de fácil interpretação, no sentido de que os nódulos das árvores representam claramente os atos comportamentais na seqüência e que um ponto de decisão está diretamente relacionado com um ato da seqüência.

\section{Árvore orientada}

Árvore orientada mais provável (Most Reliable Directed Tree) é uma técnica para construção de árvores, um método para a classificação de dados assimétricos desenvolvido por SATO (1993), podendo sua aplicação ser também observada em CROMBERG (1995). O método para obtenção das árvores orientadas mais prováveis de SATO (1993) consiste na enumeração do caminho elementar mais direto entre dois atos comportamentais. Um caminho é uma ordenação de atos. Num caminho elementar, um ato é representado apenas uma vez. Seja $(A, B, C, D)$ um caminho de $A$ para o ato D. Para atingirmos $D$, precisamos passar por $B$ e $C$, nesta ordem, assim podemos dizer que A chega em B, C, e D; B chega em $C$ e $D$ etc.

A probabilidade de um caminho, dada uma matriz de transição de primeira ordem, pode ser calculada por: 


$$
P(A, B, C, D)=p(A) p(B / A) p(C / B) p(D / C)
$$

onde: $p(A)$ é a probabilidade incondicional do ato $A$,

$p(B / A)$ é a probabilidade condicional do ato subsequente $B$ dado $o$ ato precedente $A$, etc.

De uma maneira geral, numa matriz de transição de primeira ordem, podemos ter diversos caminhos de um ato para outro. Por exemplo, $(A, C, D)$ e $(A, B, C, E . D)$, podem ser dois caminhos adicionais de A para D. Nos interessa apenas o caminho mais provável, isto é, o caminho com maior probabilidade de ocorrência.

Quando o ato selecionado começa todos os caminhos mais prováveis é chamado de FONTE. Seja $(A, B, C, D)$ o caminho mais provável da fonte $A$ para o ato $D$. Então $(A, B)$ e $(A, B, C)$ são também caminhos mais prováveis; $(A, B, C)$ não é maximal, porque existe pelo menos um caminho, o caminho $(A, B, C, D)$, que o inclui. Para acharmos o caminho mais provável da fonte $A$ para $B$ e $C$, nós não precisamos enumerar os caminhos $(A, B)$ e $(A, B, C)$ separadamente, pois toda a informação sobre estes caminhos é dada pelo caminho $(A, B, C, D)$.

Seja $(A, B, E)$ outro caminho mais provável, começando na fonte $A$. A informação nestes dois caminhos mais prováveis pode ser expressa por um diagrama de árvore orientada mostrando: 1) $A$ estrutura (inicial) A-B comum a ambos os caminhos; 2) A estrutura C-D emergindo de B como B-C-D; 3) A estrutura $E$, um ato emergindo de B como B-E. Esta árvore direta (fig. 1a) mostra duplas de atos que são relacionados pela associação seqüencial (BC) e também mostra os atos $\mathrm{C}$ e $\mathrm{E}$, como candidatos relacionados à equivalência estrutural precedente, através do ato precedente B (para confirmar este "status" nós podemos dizer que $\mathrm{C}$ e $\mathrm{E}$ não estão relacionados por associações seqüenciais). $O$ ato fonte é sempre comum a todos os caminhos que começam na fonte. $O$ resultado da união das partes comuns dos caminhos é uma árvore orientada, com raiz no ato fonte e com 
bifurcações revelando atos candidatos a serem juntados pela equivalência precedente. A cada bifurcação, o ato precedente (comum) pode ser visto como um ponto de decisão na seqüência da qual diversas alternativas podem emergir.

Cada ato do catálogo comportamental pode ser posto na posição da raiz. Assim, sendo $\mathrm{N}$ o número de atos comportamentais de um etograma, a análise das soluções fonte das árvores orientadas é constituída de $\mathrm{N}$ diagramas de árvores orientadas. Uma árvore orientada pode não atingir todos os atos a partir de um ato fonte (pois o algoritmo utilizado descarta os caminhos de probabilidade zero). Se algum comportamento não aparece numa árvore orientada, podemos gerar outras árvores a partir destes atos, para podermos visualizar como eles estão organizados. No limite deste procedimento, $\mathrm{N}$ árvores orientadas darão todas as informações que precisamos sobre a solução fonte.

A solução sumidouro da árvore orientada é análoga à solução fonte. Seja $(B, C, D, Z)$ e $(A, C, D, Z)$ dois caminhos mais prováveis terminando no sumidouro $Z$. Seja ainda $(C, D, Z)$ e $(D, Z)$ outros dois caminhos prováveis, mas não maximais. Para resumir as informações destes dois caminhos, um diagrama pode ser construído. O diagrama é composto: 1)Das estruturas comuns $C-D-Z ; 2) D o$ ato $B$ convergindo para $C(B-C) ; 3) D o$ ato $A$ convergindo para $C$ ( $A-C)$. $A$ e $B$ são candidatos para serem unidos por equivalência subsequente através do ato $C$ (fig.1b). Existe pelo menos um elemento da estrutura, o ato no sumidouro, que é comum a todos os caminhos que terminam nele (sumidouro). A árvore resultante da locação dos pontos converge para um ponto em comum, o ato no sumidouro. Cada ato comportamental do catálogo pode ser colocado na posição do sumidouro. Assim, se $\mathrm{N}$ é o número de atos do etograma, a solução de sumidouro pode ser representada por $\mathrm{N}$ diagramas de árvore orientada. 


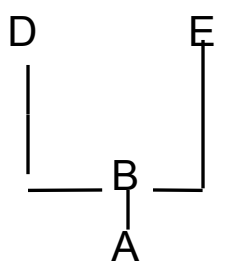

FONTE

(a)<smiles>[Z]OC(C[B])CC</smiles>

SUMIDOURO

(b)

FIGURA 1. Exemplo hipotético de árvores orientadas com solução fonte e sumidouro (ver texto acima).

\section{MOST RELIABLE DITREE}

Extraído de SATO (1993)

BUSACKER \& SAATY (1965) propõem um procedimento para a construção de árvores orientadas. Em linhas gerais parte-se de um grafo: $G$ $=(\mathrm{V}, \mathrm{A})$

onde:

$V$ - é o conjunto de vértices (elementos, indivíduos, comportamentos, etc.) que se quer analisar;

A - Conjunto de arcos (o valor do arco representa a força da relação entre dois vértices)

A relação entre os vértices pode ser de distância ou de similaridade. No presente trabalho interesso-se por grafos completos, os quais contém um arco para cada diferente par ordenado de vértices. Um caminho pode ser identificado pela enumeração de todos os vértices que ele atravessa, ou seja, é uma sucessão de arcos do vértice inicial até o final. Se nenhum vértice é repetido, o caminho é chamado de elementar.

Uma árvore orientada $T=\left(V, A^{\prime}\right)$ com um vértice $R$ selecionado como raiz para outros vértices (caso em que a raiz é fonte) é um grafo parcial de $G$ onde apenas um selecionado número de arcos de $A$ está presente ( $A^{\prime}$ é um subgrupo de $A$ ). A seleção segue às seguintes restrições: 
a) R é o vértice inicial de todos caminhos maximais (um caminho que não é repetido por outro caminho).

b) existe um único caminho de $\mathrm{R}$ para cada um dos outros vértices. Se o caminho é mínimo para cada vértice i de $\mathrm{V}$ e $\mathrm{R}$ é diferente de i, então $\mathrm{T}$ é a árvore orientada de distância mínima.

Para acharmos a árvore orientada de mais provável com raiz como sumidouro segue-se os passos: 1)construa qualquer $T=\left(V, A^{\prime}\right)$ com raiz $R$ como sumidouro onde:

a) R é o vértice terminal para todos os caminhos maximais;

b) existe um único caminho de todos os outros vértices para $R$

2) se o caminho de T obedece:

$\mathrm{L}(\mathrm{i} \ldots, \mathrm{R}) \bullet \mathrm{L}(\mathrm{j}, \ldots, \mathrm{R})+\mathrm{a}(\mathrm{i}, \mathrm{j}) \quad$ onde :

$L(i, R)$ - é o comprimento do caminho de i a $R$

a(i,j) - é o comprimento do arco em G de i para j, para todo i e j Q V

Para cada arco $(i, j)$ de $A, i \odot R, i \oplus j$, então $T$ é a árvore orientada mais provável com raiz $\mathrm{R}$ no sumidouro.

Uma matriz de transição de primeira ordem é um grafo no qual os arcos representam similaridades, em vez de distâncias. Se as células de uma matriz de transição são convertidas para probabilidades condicionais, então $\mathrm{C}(\mathrm{i}, \mathrm{j})$ é a probabilidade condicional do ato j, dado o precedente ato $\mathrm{i}$, isto é, $c(i, j)=p(j / i)$, e $p(R)$ é a probabilidade (incondicional) do ato $R$, então a probabilidade de percorrer o caminho $(R, \ldots, I)$ é:

$$
P(R, \ldots ., I)=\frac{p(R) \cdot c(i, j)}{(i, j)(R, \ldots l)} \quad \text { Equação } 1
$$

Se T é a árvore mais provável, então T deve concordar com uma das seguintes condições: 


$$
\begin{array}{ll}
P(R, \ldots . j) \square P(R, \ldots . j) c(i, j), & R \text { é fonte - } \quad \text { Equação 2a } \\
P(i, \ldots, R) \square P(j, \ldots, R) c(i, j) p(i) / p(j), & R \text { é sumidouro - Equação 2b }
\end{array}
$$

para cada arco $(\mathrm{i}, \mathrm{j})$ de $\mathrm{A}, \mathrm{i} \mapsto \mathrm{j}$ (os passos são similares aos empregados por BUSACKER \& SAATY 1965)

Se utilizarmos matrizes de transição com muitos zeros, os diagramas obtidos tendem a ser pouco informativos com muitos "ramos"(dizemos que o diagrama parece mais uma moita do que uma árvore). Portanto, após calcular a probabilidade condicional de primeira ordem, emprega-se apenas as células, nas quais o valor observado é estatisticamente acima do valor esperado de $(\mathrm{Oij}-\mathrm{Eij}) /\left(\mathrm{Eij}_{\mathrm{ij}}\right)^{1 / 2}$ 口 2,58 segundo ASPEY (1977), depois de zeradas as células da diagonal (BISHOP et al., 1975).

Essencialmente o algoritmo é o seguinte:

Inicialização :

A) Construa uma matriz absoluta de transição de primeira ordem a partir das seqüências de comportamento (linhas: atos precedentes; colunas: atos conseqüentes)

B) Construa a matriz de probabilidade condicional de primeira ordem;

C) Se a transição observada não é estatisticamente acima da esperada, ponha zero na célula correspondente na matriz de probabilidade condicional de primeira ordem. A matriz resultante é um grafo $G=(V, A)$, para $V o$ conjunto de arcos e A o conjunto das probabilidades condicionais de primeira ordem;

D) Construa qualquer árvore orientada $T=\left(\mathrm{V}, \mathrm{A}^{\prime}\right)$, para $\mathrm{A}^{\prime}$ um subconjunto de $A$, com raiz numa especificada fonte $R$; usando a equação 1 , ache a probabilidade de todos os caminhos de $T$ que se iniciam em $R$.

Passos:

1) Se o caminho de $T$ obedece a equação $2 a$, para cada arco $(i, j)$ de $A$, $i \oplus$ j, então PARE ( $T$ é o caminho mais provável da árvore orientada com raiz na fonte $R$ do grafo $G=(V, A)$; 
2) De outro modo modifique a árvore $T$ como se segue:

a) selecione qualquer arco $(i, j)$ de $A$ que não satisfaça a equação $2 a$;

b) Disconecte $T$ apagando o arco de $T$ cujo vértice terminal seja j;

c) Reconecte $T$ adicionando o arco $(\mathrm{i}, \mathrm{j})$;

d) Recalcule a probabilidade dos caminhos de $T$ que foram modificados neste passo;

3) Vá para o passo 1.

Para acharmos a árvore orientada mais provável com raiz no sumidouro, proceda do seguinte modo:

Inicialização:
A, B, C: igual a anterior;

Passos:

1) Se o caminho $T$ obedece a equação $2 b$, para cada arco $(i, j)$ de $A, i \oplus j$, então PARE ( $T$ é a árvore orientada mais provável com raiz $R$ no sumidouro do grafo $G=(V, A)$;

2) Caso contrário modifique a árvore orientada como se segue:

a) selecione qualquer arco $(\mathrm{i}, \mathrm{j})$ de $\mathrm{A}$ que não satisfaça a equação $2 \mathrm{~b}$;

b) disconecte $\mathrm{T}$ apagando o arco de $\mathrm{T}$, cujo vértice inicial é $\mathrm{i}$;

c) reconecte $\mathrm{T}$ adicionando o arco $(\mathrm{i}, \mathrm{J})$

d) recalcule a probabilidade do caminho de $T$ que foi modificado por este passo;

3) vá para o passo 1 
ANEXO B

de ar cs1 am co sp sa be sam cç er as bp pa es2

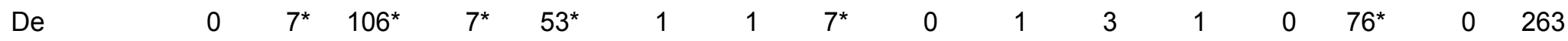

$\begin{array}{llllllllllllllllllll}\operatorname{Ar} & 16^{*} & 0 & 2 & 0 & 0 & 0 & 0 & 0 & 0 & 1 & 1 & 0 & 0 & 9^{*} & 0 & 29\end{array}$

$\begin{array}{lllllllllllllllllll}\operatorname{cs} 1 & 100^{*} & 2 & 1 & 1 & 2 & 0 & 0 & 0 & 0 & 1 & 0 & 0 & 0 & 0 & 0 & 107\end{array}$

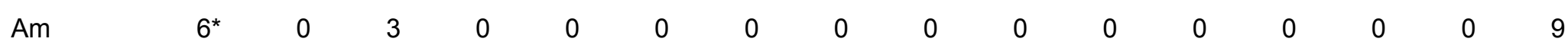

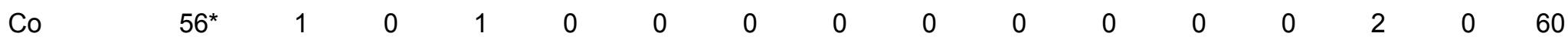

$\begin{array}{llllllllllllllllllllll}\mathrm{Sp} & 1 & 0 & 0 & 0 & 0 & 0 & 6^{*} & 0 & 0 & 0 & 0 & 0 & 0 & 0 & 0 & 7\end{array}$

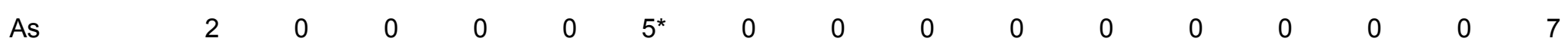

$\begin{array}{lllllllllllllllll}\mathrm{Be} & 3 & 0 & 3 & 0 & 0 & 0 & 0 & 0 & 0 & 0 & 0 & 0 & 0 & 1 & 0 & 7\end{array}$

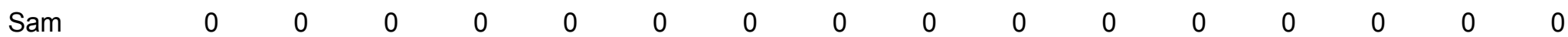

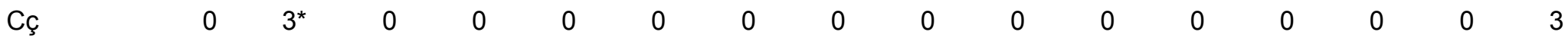

$\begin{array}{lllllllllllllllllllll}\text { Er } & 3 & 1 & 0 & 0 & 0 & 0 & 0 & 0 & 0 & 0 & 0 & 0 & 0 & 0 & 0 & 4\end{array}$

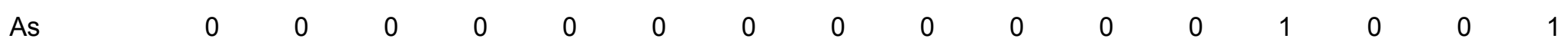

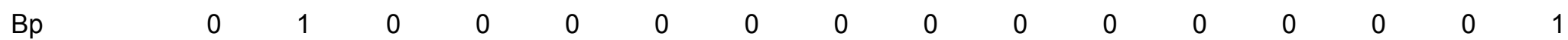

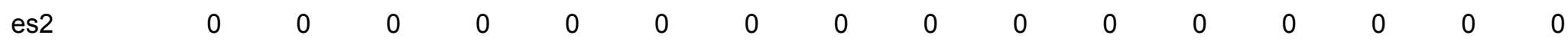

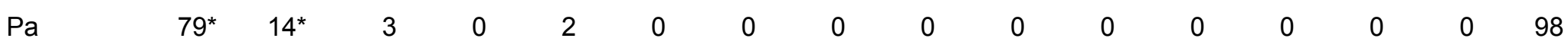

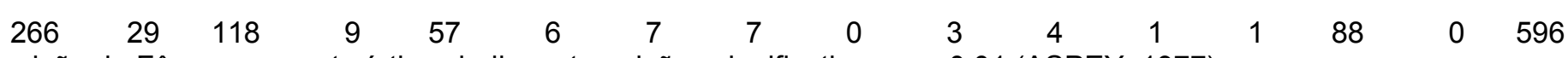

Matriz de Transição de Fêmeas, os asterísticos indicam transições significativas a o<0,01 (ASPEY, 1977) 